Nattona Bureau of Standarcts

Library, E-01 Admin, BldG:

NOV 251969
Referesco 'm-1: ma:":o ba

taken fiom sic tuarly.

NATIONAL BUREAU OF STANDARDS

SPECIAL PUBLICATION 315-3

\title{
BIBLIOGRAPHY ON THE
}

\section{HIGH TEMPERATURE CHEMISTRY}

AND PHYSICS OF MATERIALS

JULY, AUGUST, SEPTEMBER 1969 


\section{NATIONAL BUREAU OF STANDARDS}

The National Bureau of Standards ${ }^{1}$ was established by an act of Congress March 3, 1901. Today, in addition to serving as the Nation's central measurement laboratory, the Bureau is a principal focal point in the Federal Government for assuring maximum application of the physical and engineering sciences to the advancement of technology in industry and commerce. To this end the Bureau conducts research and provides central national services in four broad program areas. These are: (1) basic measurements and standards, (2) materials measurements and standards, (3) technological measurements and standards, and (4) transfer of technology.

The Bureau comprises the Institute for Basic Standards, the Institute for Materials Research, the Institute for Applied Technology, the Center for Radiation Research, the Center for Computer Sciences and Technology, and the Office for Information Programs.

THE INSTITUTE FOR BASIC STANDARDS provides the central basis within the United States of a complete and consistent system of physical measurement; coordinates that system with measurement systems of other nations; and furnishes essential services leading to accurate and uniform physical measurements throughout the Nation's scientific community, industry, and commerce. The Institute consists of an Office of Measurement Services and the following technical divisions:

Applied Mathematics-Electricity-Metrology-Mechanics-Heat-Atomic and Molecular Physics-Radio Physics"-Radio Engineering"-Time and Frequency "-Astro-

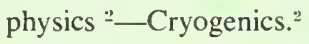

THE INSTITUTE FOR MATERIALS RESEA RCH conducts materials research leading to improved methods of measurement standards, and data on the properties of well-characterized materials needed by industry, commerce, educational institutions, and Government; develops, produces, and distributes standard reference materials; relates the physical and chemical properties of materials to their behavior and their interaction with their environments; and provides advisory and research services to other Government agencies. The Institute consists of an Office of Standard Reference Materials and the following divisions:

Analytical Chemistry_Polymers-Metallurgy_-Inorganic Materials_Physical Chemistry.

THE INSTITUTE FOR APPLIED TECHNOLOGY provides technical services to promote the use of available technology and to facilitate technological innovation in industry and Government; cooperates with public and private organizations in the development of technological standards, and test methodologies; and provides advisory and research services for Federal, state, and local government agencies. The Institute consists of the following technical divisions and offices:

Engineering Standards-Weights and Measures - Invention and Innovation — Vehicle Systems Research-Product Evaluation-Building Research-Instrument Shops-Measurement Engineering-Electronic Technology-Technical Analysis.

THE CENTER FOR RADIATION RESEARCH engages in research, measurement, and application of radiation to the solution of Bureau mission problems and the problems of other agencies and institutions. The Center consists of the following divisions:

Reactor Radiation-Linac Radiation-Nuclear Radiation-Applied Radiation.

THE CENTER FOR COMPUTER SCIENCES AND TECHNOLOGY conducts research and provides technical services designed to aid Government agencies in the selection, acquisition, and effective use of automatic data processing equipment; and serves as the principal focus for the development of Federal standards for automatic data processing equipment, techniques, and computer languages. The Center consists of the following offices and divisions:

Information Processing Standards-Computer Information - Computer Services - Systems Development-Information Processing Technology.

THE OFFICE FOR INFORMATION PROGRAMS promotes optimum dissemination and accessibility of scientific information generated within NBS and other agencies of the Federal government; promotes the development of the National Standard Reference Data System and a system of information analysis centers dealing with the broader aspects of the National Measurement System, and provides appropriate services to ensure that the NBS staff has optimum accessibility to the scientific information of the world. The Office consists of the following organizational units:

Office of Standard Reference Data-Clearinghouse for Federal Scientific and Technical Information "-Office of Technical Information and Publications-Library-Office of Public Information-Office of International Relations.

${ }^{1}$ Headquarters and Laboratories at Gaithersburg. Matyland, unless otherwise noted; mailing address Washington, D.C. 20234.

" Located at 5285 Port Royal Road, Springfield, Virginia 22151. 


\section{BIBLIOGRAPHY ON THE \\ HIGH TEMPERATURE CHEMISTRY AND PHYSICS OF MATERIALS}

July, August, September

1969

J. J. Diamond, Editor

Institute for Materials Research

National Bureau of Standards

Washington, D. C. 20234

Under the auspices of the

International Union of Pure and Applied Chemistry

Commission on High Temperatures and Refractories

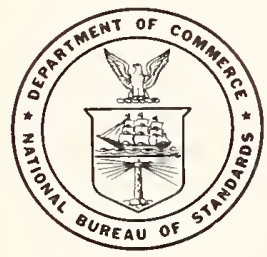

L. $S$, National Bureau of Standards Special Publication 315-3,

to Nat. Bur. Stand. (U.S.), Spec. Publ. 315-3, 90 pages (October 1969)

CODEN : XNBSA

Issued October 1969 
NATIONAL BUREAU OF STANDARDS अ 121970

be:00

1) 5 ?

No. 3/5-3

1969

coper 1

Library of Congress Catalog Card Number: 77-600413 


\section{Contributors}

\section{PART I. Compiled by}

N. F. H. Bright, Department of Energy, Mines and Resources, Ottawa, Ontario, Canada.

J. J. Diamond, National Bureau of Standards, Washington, D. C., U.S.A.

H. Flood, Norwegian Institute of Technology, Trondheim, Norway.

M. Foex, C.N.R.S., Super-Refractories Laboratory, Odeillo, France.

M. G. Hocking, Imperial College of Science and Technology, London, England.

H. Nowotny, University of Vienna, Vienna, Austria.

G. D. Rieck, Eindhoven Institute of Technology, Eindhoven, Netherlands.

A. Wittmann, Vienna Institute of Technology, Vienna, Austria.

\section{PART II. Compiled by}

L. Brewer, University of California, Berkeley, California, U.S.A. 


\section{Contents}

\section{PART I. Solids and Liquids}

A. Devices for achieving temperatures above $1500{ }^{\circ} \mathrm{C}$

Page

B. Devices for measuring and controlling temperatures above $1500{ }^{\circ} \mathrm{C}$

C. Devices for physical measurements at temperatures above $1000{ }^{\circ} \mathrm{C}$

D. Thermodynamic properties, at temperatures below $1000{ }^{\circ} \mathrm{C}$, of materials which melt above $1500{ }^{\circ} \mathrm{C}$

E. Properties, at temperatures above $1000{ }^{\circ} \mathrm{C}$, of materials which melt above $1500{ }^{\circ} \mathrm{C}$

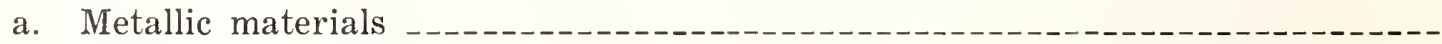

b. Non-metallic materials

c. Mixed materials

F. Properties, at temperatures above $1000{ }^{\circ} \mathrm{C}$, of materials which melt below $1500{ }^{\circ} \mathrm{C}$

a. Metallic materials _-__-_.

b. Non-metallic materials ____-__- 17

c. Mixed materials _-_-_-_- 19

G. Phase equilibria above $1000{ }^{\circ} \mathrm{C}$

$\mathrm{H}$. Reactions at temperatures above $1000^{\circ} \mathrm{C}$

I. Books _-__

\section{PART II. Gases}

A. Spectroscopy of interest to high temperature chemistry --_-

B. Reaction between gases and condensed phases 


\section{PREFACE}

This is one of a series of current-awareness bibliographies on high-temperature chemistry and physics published under the auspices of the Commission on High Temperatures and Refractories of the International Union of Pure and Applied Chemistry. The first issue covered the period October-December 1957 and, with several changes in title, format and content, the series has appeared quarterly since that time. It acquired its present format and status as a National Bureau of Standards publication with the issue covering the fourth quarter of 1968.

It is compiled by an International Working Group on Bibliographies, attached to the Commission, consisting of about fifteen scientists. Part I is compiled by the Contributors scanning the pertinent journals published in their countries and in some cases, of adjacent countries, while the literature of other countries is covered by the editor, mainly from published Iists of tables of contents. Part II is obtained by searching Chemical Abstracts.

With very few exceptions, abbreviations of journal names follow the usage of Chemical Abstracts. Journal names using non-Roman alphabets are transilterated when the original is being referenced. In those cases where translation journals are referenced its name and pagination are used.

A11 titles are translated into English. Translations are by the contributors, the editor, Chemical Abstracts, or those published in table of contents lists. 

Bibliography on the High Temperature Chemistry and Physics of Materials

July, August, September 1969

J. J. Diamond, Editor

The bibliography consists of references to research involving temperatures above $1000{ }^{\circ} \mathrm{C}$, which were noted by the Contributors during the above three-month period. Since this is intended primarily as a current-awareness bibliography, there is no cross-referencing or indexing. This issue contains about 825 references roughly grouped under fifteen subject headings.

Key words: Bibliography, high temperature; chemistry, high temperature; high temperature chemistry; materials properties; research at high temperatures; thermophysical properties.

\section{Part I. SOLIDS AND LIQUIDS}

A. Devices for achieving temperatures above $1500{ }^{\circ} \mathrm{C}$

1. The arc transfer process of crystal growth

J. R. Drabble (Phys. Dept., Univ. of Exeter, Eng1.)

J. Crystal Growth 3-4, 804-07 (1968)

2. Thermal imaging for single crystal growth and its application to ruby

W. G. Field and R. W. Wagner (A. F. Cambridge Res. Lab., Bedford, Mass. 01730)

J. Crystal Growth 3-4, 799-803 (1968)

3. Melting of metals in a suspended state during electron beam heating A. A. Fogel and I. V. Korkin

Izv. Akad. Nauk SSSR, Metal [3], 67-71 (May-June 1969)

4. A high-temperature forge for refractory metals

C. E. Habermann, A. L. Rafalski and R. D. Hansen (Phys. Res. Lab., Dow Chem. Co., Midland, Mich. 48640)

J. Less-Common Metals 18 [2], 105-09 (1969)

5. Fusion of VC in a plasma jet furnace

K. Hanusch and $\mathrm{H}$. Winterhager

Chem.-Ing.-Tech. 41 [11], 687-88 (1969)

6. Thermodynamics of radiative heat transfer in furnaces

A. D. Iskhakov

Vestn. Akad. Nauk Kaz. SSR 25 [7], 37-43 (July 1969) 
A. 7. Trials of solar heat receptors at the CNRS Solar Energy Laboratory A. Le Phat Vinh, B. Delfolie, E. Le Grives and F. Charron (CNRS

Lab. Energie Solaire, 66-Odeillo, P.-0., Fr.)

Rev. Gén. Thermique 8, 455 (1969)

8. Interior resistance heated open tube epitaxial reactor

I. F. Nicolau (Lab. Semicond., Rumania)

J. Sci. Instr. 2, 782-84 (1969)

9. A floating zone technique for the growth of carbide single crystals

W. Precht and G. E. Hollox (Res. Inst. Adv. Studies, Martin

Marietta Co., 1450 South Rolling Road, Baltimore, Md. 21227)

J. Crystal Growth 3-4, 818-23 (1968)

10. Design and construction of a high pressure multipurpose crystal growing furnace

J. F. Wenckus and P. R. Doherty (A. D. Little Inc., Cambridge, Mass. 02140)

J. Crystal Growth 3-4, 301 (1968)

B. Devices for measuring and controlling temperatures above $1500^{\circ} \mathrm{C}$

1. Electronic equipment for measuring the temperature of transient processes in the range $500-2000 \mathrm{~K}$

A. A. Anufriev, V. F. Vshola and L. A. Novitskii

Measur. Tech. (transl. of Izmeritel. Tekh.) [11], 1477-80 (1968)

2. Temperature measurements with $\mathrm{W}-\mathrm{Re}$ and $\mathrm{W}-\mathrm{Mo}$ thermocouples and their calibration methods

N. N. Ergardt

Measur. Tech. (transl. of Izmeritel. Tekh.) [10], 1335-38 (1968)

3. Emissivity of a cylindrical cavity in the presence of a temperature gradient

V. B. Fedorov and V. S. Egorov

High Temp. 6 [3], 473-76 (1968)

4. Automatic USP-1 spectropyrometer for accurate temperature measurements

V. E. Finkelshtein, L. M. Golub, A. N. Kisel and P. G. Shitilova (Kharkov Inst. Measur. \& Measur. Instr.)

High Temp. 6 [4], 729-32 (1968)

5. A system for the automatic programmed control of temperature

V. A. Gordeyev, A. T. Yakunin and V. M. Obukhov (Dzerzhinskii Glass Factory, Gusev, USSR)

Steklo Keram. [7], 5-6 (July 1969)

6. The International Practical Temperature Scale of 1968

International Committee on Weights and Measures

Metrologia 5 [2], 35-44 (1969) 
B. 7. Know your thermocouples for better temperature control

H. Koenen (West Instrument Corp.)

Can. Controls Instr. 8 [5], 30-33 (1969)

8. Special features of the optical systems of visual pyrometers and the accuracy of temperature measurements

A. V. Kogan (Lvov Construction Bur. "Termopribor")

High Temp. 6 [3], 493-97 (1968)

9. High-temperature thermocouple from graphite

V. N. Malyshev

Zavod. Lab. 35 [7], 888 (1969)

10. Effective emittance of a cylindrical cavity with diffusion and a mirror character of the reflection

S. P. Rusin (All-Union Res. Inst. Electrothermal Equip.)

High Temp. 6 [3], 529-31 (1968)

11. W-Re thermocouples for periodically checking the temperature in furnaces for the fire refining of $\mathrm{Cu}$

L. S. Terebukh and 5 others (Inst. Probl. Mater. Sci., Acad. Sci. Ukr. SSR)

High Temp. 6 [6], 1045-47 (1968)

C. Devices for physical measurements at temperatures above $1000{ }^{\circ} \mathrm{C}$

1. Effusion. V. Angular number distributions of gaseous CsCl from a conical orifice into vacuum

J. Q. Adams and T. E. Phipps (Chem. \& Chem. Eng. Dept., Univ. of Illinois, Urbana) and P. G. Wahlbeck (Chem. Dept., Illinois Inst. Tech., Chicago, Ill. 60616)

J. Chem. Phys. 51 [3], 920-23 (1969)

2. Design and construction of an absolute recording dilatometer operable at high temperature in controlled atmosphere. Use for the study of the behavior of argillaceous minerals

A. Baudran (Soc. Franc. Céram.)

Bull. Soc. Franc. Céram. [82], 3 (1969)

3. Rotational viscometer for viscosity coefficient measurement of melts of high-melting materials

I. S. Belevich, V. N. Kirillov and Yu. P. Menchev

Zavod. Lab. 35 [7], 881-83 (1969)

4. Differential thermal analysis at high pressures and temperatures

N. A. Bendeliani and L. F. Vereshchagin (Acad. Sci., Inst. Phys. High Pressures, Moscow)

Zh. Fiz. Khim. 43 [6], 1631-32 (1969)

5. Method of high-temperature testing ceramic filamentary crystals for strength

T. I. Bulygina, G. N. Zaitsev, M. P. Nazarova and I. L. Svetlov Zavod. Lab. 35 [6], 731 (1969) 
C. 6. High temperature probe for EPR measurements

E. M. deCastro and V. Pereira (Inst. Fis., Pontif. Univ. Catol. do Rio de Janeiro, Brazil)

Rev.Sci. Instr. 40 [7], 949 (1969)

7. Method for measuring the thermal conductivity of refractories at high temperature

A. de Smet (Ctr. Etudes Matér. Réfract., Soc. Claverbel, Boussois, Souchon, Neuvesel et Delog, Roux, Belgium)

Rev. Int. Hautes Tempér. Réfract. 6 [2], 83 (1969)

8. Recent developments with high-temperature, high-pressure autoclaves for powder-metallurgical products, especially hard metals

P. Ettmayer, H. Priemer and R. Kieffer (Inst. Chem. Tech. Anorg. Stoffe, Tech. Hochschule Wien, Austria)

Metall 23, 307-10 (1969)

9. A drop calorimeter with an electron beam heated furnace

D. R. Fredrickson, R. Kleb, R. I. Nuttall and W. N. Hubbard

(Argonne Nat. Lab., Argonne, Ill. 60439)

Rev. Sci. Instr. 40 [8], 1022-25 (1969)

10. Development of a galvanic cell for the determination of oxygen in liquid steel

R. J. Fruehan, L. J. Martonik and E. T. Turkdogan (U. S. Steel Lab. Fundmtl. Res., Monroeville, Pa.)

Trans. Met. Soc. AIME 245 [7], 1501-09 (1969)

11. Development of high temperature capacitance strain gauges

0. L. Gillette (Hughes Aircraft Co., Los Angeles, Calif.) and J. L. Mullineaux (A. F. Flight Dynamics Lab., Wright-Patterson $\mathrm{AFB}$, Ohio)

ISA (Instr. Soc. Am.) Trans. $\underline{8}$ [1], 52-61 (1969)

12. Apparatus for $\mathrm{x}$-ray measurements on reactive materials at $2500{ }^{\circ} \mathrm{C}$ E. A. Harper (AERE, Harwell, U. K.)

J. Sci. Instr. 2, 807-09 (1969)

13. Effect of thermoelectric emission of solids on the measurement of electrical conductivity at high temperature ( $\mathrm{T}>1700 \mathrm{~K}$ )

N. Jonkiere and A. M. Anthony (Ctr. Rech. Phys. Hautes Tempér., 45-Orléans/La Source, Fr.)

C. R. Acad. Sci. 268B, 1459 (1969)

14. Cell for measuring the thermal emf of semiconductors in the molten state

B. I. Kazandzhan

Pribory Tekhn. Eksperim. [3], 196-97 (1969)

15. System for testing for torsion at temperatures up to $2500{ }^{\circ} \mathrm{C}$ A. A. Kulbakh, B. A. Blosfeld, V. N. Chechko and B. A. Makarychev Zavod. Lab. 35 [5], 623 (1969) 
16. Device for testing precious metals and alloys for creep at temperatures up to $1700{ }^{\circ} \mathrm{C}$

V. V. Malashkin

Zavod. Lab. 35 [6], 757 (1969)

17. A method of studying the diffusion of low-concentration interstitial impurities

G. Melchior (Max Planck Inst. Metallforsch., Inst. Sondermetalle, Stuttgart, Germ.)

J. Less-Common Metals 17 [4], 443-46 (1969)

13. Measurement of the oxidation potential of the gas phase by the emf method at temperatures to $1600^{\circ}$

S. P. Pednekar, V. P. Luzg in and V. I. Yavoiskii

Izv. Vyssh. Ucheb. Zaved,, Chern. Met. 12 [5], 36-38 (May 1969)

19. New experimental apparatus for the investigation of the coefficient of thermal conductivity of electrically conductive materials in the temperature range 500-3000 $\mathrm{K}$

V. E. Peletskii and Ya. G. Sobol (Inst. High Temp., Acad. Sci. USSR, Moscow)

High Temp. $\underline{6}[6], 1054-60$ (1968)

20. Recent aspects of high temperature cryometry. II. Determination of a chemical reaction by the cryometric method

G. Petit and C. Bourlange (Lab. Phys. Gén., Fac. Sci. Paris)

Rev. Int. Hautes Tempér. Réfract. 6 [2], 121 (1969)

21. High-temperature testing of filamentary crystals

V. S. Postnikov and 5 others

Zavod. Lab. $\underline{35}[6], 732-33$ (1969)

22. Directivity diagram of dissociating gas discharge from a Knudsen chamber

G. F. Voronin (Lomonosov State Univ., Moscow)

Zh. Fiz. Khim. 43 [5], 1320 (1969)

23. Device for measuring the thermal emf coefficient of high-melting compounds in the temperature range $40-1300{ }^{\circ} \mathrm{C}$

V. L. Yupko

Zavod. Lab. 35 [6], 754 (1969)

24. Special features of the resonance method of measuring the modulus of elasticity of anisotropic graphites using the frequency of longitudinal vibration of the specimen in the range $20-3000{ }^{\circ} \mathrm{C}$ G. G. Zaitsev, V. N. Zmeeva and V. N. Barabanov

Zavod. Lab. 35 [6], 736-38 (1969)

25. An apparatus for studying gas permeability and its mixtures through metals at temperatures up to $1500{ }^{\circ} \mathrm{C}$

A. P. Zakharov, N. A. Shuster, E. I. Evko, V. M. Lukyanovich and A. A. Babad-Zakhryapin

Zavod. Lab. 35 [7], 877-78 (1969) 
D. Thermodynamic properties, at temperatures below $1000^{\circ} \mathrm{C}$, of materials which melt above $1500{ }^{\circ} \mathrm{C}$

1. Heat capacity measurements on rare earth double oxides H. W. J. Bloete, R. F. Wielinga and W. J. Huiskamp Physica 43 [4], 549-68 (1969)

2. The heat capacities of $\mathrm{Al}_{2} \mathrm{O}_{3}, \mathrm{UO}_{2}$ and $\mathrm{PuO}_{2}$ from 300 to $1100 \mathrm{~K}$ T. K. Engel (Monsanto Res. Co., Mound Lab., Miamisburg, Ohio) J. Nucl. Mater. 31 [2], 211-14 (1969)

3. $\mathrm{UB}_{2}$ : preparation, enthalpy of formation at $298.15 \mathrm{~K}$, heat capacity from 1 to $350 \mathrm{~K}$, and some derived thermodynamic properties

H. E. Flotow and 5 others (Argonne Nat. Lab., Argonne, Ill. 60439)

J. Chem. Phys. 51 [2], 583-92 (1969)

4. Specific heat of $\alpha-\mathrm{Al}_{2} \mathrm{O}_{3}$ from 2 to $25 \mathrm{~K}$

R. Q. Fugate and C. A. Swenson (Phys. Dept., Iowa State Univ., Ames, Iowa 50010)

J. Appl. Phys. 40 [7], 3034-36 (1969)

5. Heat capacities and thermodynamic properties of $\alpha-\mathrm{Be}_{3} \mathrm{~N}_{2}$ from 25 to $310 \mathrm{~K}$

B. H. Justice (Thermal Res. Lab., Dow Chem. Co., Midland, Mich. 48640)

J. Chem. Eng. Data 14 [3], 384-86 (1969)

6. Thermophysical properties of the lanthanide oxides. V. Heat capacity, thermodynamic properties and energy levels of $\mathrm{Ce}_{2} \mathrm{O}_{3}$

B. H. Justice and E. F. Westrum, Jr. (Chem. Dept., Univ. of Michigan, Ann Arbor, Mich. 48104)

J. Phys. Chem. $\underline{73}[6], 1959-62$ (1969)

7. Thermal properties of single crystal Mo at high temperatures B. N. Khusainova and L. P. Filippov (Lomonosov State Univ., Moscow) High Temp. 6 [5], 891-92 (1968)

8. Heat capacity of tantalum nitride between 15 and $300 \mathrm{~K}$ V. V. Nogteva, I. E. Paukov, P. G. Strelkov and V. S. Filatkina Zh. Fiz. Khim. 43 [5], 1108-11 (1969)

9. The specific heat and paramagnetic susceptibility of stoichiometric and reduced rutile $\left(\mathrm{TiO}_{2}\right)$ from 0.3 to $20 \mathrm{~K}$

T. R. Sandin (Purdue Univ., 1968)

Dissertation Abstr. 29B [11], 4344 (1968-69)

10. Thermodynamic characteristics of refractory carbides in the homogeneity region

A. G. Turchanin and V. V. Fesenko

Porosh. Met. $\underline{9}$ [6], 48-52 (June 1969) 
E. Properties, at temperatures above $1000{ }^{\circ} \mathrm{C}$, of materials which melt above $1500^{\circ} \mathrm{C}$

a. Meta11ic materials

1. Thermodynamic study of the $\gamma$ phase solid solutions formed between $\mathrm{Pd}, \mathrm{Pt}$ and $\mathrm{Fe}$

C. B. Alcock (Met. Dept., Imperial Col1., London, SW 7) and

A. Kubik (Ctr. Rech. Microcalorim. Thermochim., Marseille, Fr.) Acta Met. 17 [4], 437-42 (1969)

2. Kinetics of grain boundary grooving in $\mathrm{Cr}$, Mo, and $\mathrm{W}$ B. C. Allen (Battelle Memorial Inst., Columbus, Ohio)

Trans. Met. Soc. AIME 245 [7], 1621-32 (1969)

3. The surface free energy of solid Mo

B. C. Allen (Battelle Mem. Inst., Columbus, Ohio 43201 )

J. Less-Common Metals 17 [4], 403-10 (1969)

4. Thermal stability of $\mathrm{Ta}$ and $\mathrm{Cr}$ diborides and their alloys

B. G. Arabei, K. I. Frolova and R. S. Tikhonova

Zashch. Metal. 5 [4], 417-21 (1969)

5. Investigation of the strength properties of $\mathrm{Ni}_{3} \mathrm{Al}-\mathrm{Ni}_{3} \mathrm{Nb}$ alloys at high temperatures

M. P. Arbuzov, V. K. Kharchenko and V. G. Chuprina (Acad. Sci., Mater. Tech. Inst., Kiev, UkSSR)

Izv. Vys. Ucheb. Zaved., Fiz. [7], 55-59 (July 1969)

6. Dissociation energy of $\mathrm{Ce}_{2}$

G. Balducci, G. DeMaria and M. Guido (Ist. Chim. Fis., Univ. di Roma, Rome, Ita1y)

J. Chem. Phys. 50 [12], 5424-25 (1969)

7. Thermal conductivity at high temperature for articles pressed from tungsten wire screening

L. G. Barabanova, S. G. Murovannaya and E. N. Marmer

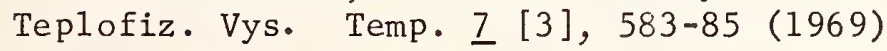

8. Experimental measurement of the enthalpy of Mo at extremely high temperatures

V. Ya. Chekhovskoi and V. A. Petrov (Inst. High Temp., Acad. Sci. USSR, Mos cow)

High Temp. 6 [4], 717-18 (1968)

9. Mean adsorption lifetimes and activation energies of $\mathrm{Ag}$ and $\mathrm{Au}$ on clean, oxygenated, and carburized $W$ surfaces

A. Y. Cho and C. D. Hendricks (Electr. Eng. Dept., Univ. of I11inois, Urbana, I11. 61801)

J. App1. Phys. 40 [8], 3339-45 (1969) 
Ea. 10. Spectral emittance of $\mathrm{Mo}, \mathrm{Ta}, \mathrm{Nb}$ and $\mathrm{Zr}$ in the infrared region of the spectrum

V. D. Dmitriev and G. K. Kholopov

High Temp. $\underline{6}$ [3], 527-28 (1968)

11. Spectral and integral radiating power of Mo

V. D. Dmitriev and G. K. Kholopov

Teplofiz. Vys. Temp. 7 [3], 438-43 (1969)

12. Morphological changes in a $W$ point by surface diffusion: formation of "solid drops"

M. Drechsler (CNRS Lab. Méc. Croissance Crist., Fac. Sci., St.-Jérôme, Univ. d'Aix-Marseille, Fr.) and A. Piquet, R. Uzan and Vu Thien Binh (Lab. Emission Electr., Fac. Sci., Villeurbanne, Univ. de Lyon, Fr.)

Surface Sci. 14 [2], 457-60 (1969)

13. Electrical properties of Ta carbide at high temperatures

O. A. Golikova, E. 0. Dzhafarov, A. O. Avgustinik and G. M. Klimashin (Acad. Sci., Inst. Semicond., Leningrad, USSR)

Fiz. Tverd. Tela 11 [8], 2395-96 (1969)

14. Thermodynamic properties of $\mathrm{LaB}_{6}$

S. P. Gordienko, E. A. Guseva and V. V. Fesenko (Inst. Probl. Mater. Sci., Acad. Sci. Ukr. SSR)

High Temp. 6 [5], 785-89 (1968)

15. Microstructure and mechanical behavior of carbides

G. E. Hollox (Res. Inst. Adv. Studies, Martin Marietta Co., Baltimore, Md. 21227)

Mater. Sci. Eng. $\underline{3}$ [3], 121-37 (1968-69)

16. Vapor pressure data for the solid and liquid elements

R. E. Honig and D. A. Kramer (RCA Labs., Princeton, N. J. 08540)

RCA Review 30 [2], 285-305 (1969)

17. High temperature changes in the enthalpy of the higher V, Co, and Ni silicides

G. I. Kalishevich, P. V. Geld and Yu. V. Putintsev (Ural Polytech. Inst.)

High Temp. $\underline{6}[6], 959-62$ (1968)

18. Dissociation energies of $\mathrm{Ti}_{2}$ and $\mathrm{V}_{2}$

A. Kant and S. S. Lin (Army Mater. \& Mechan. Res. Ctr., Watertown, Mass. 02172)

J. Chem. Phys. 51 [4], 1644-47 (1969)

19. Time-of-flight mass spectrometric investigation of the positive ion emission of $\mathrm{W}$ filament

O. Kaposi, M. Riedel and D. Sztaniszlav

Magy. Kem. Foly. 75 [8], 324-30 (1969) 
Ea. 20. Thermoelectronic parameters of Re single crystal faces

A. Kashetov and N. A. Gorbatii (Lenin Univ., Tashkent, UzSSR)

Izv. Vys. Ucheb. Zaved., Fiz. [7], 37-41 (July 1969)

21. Thermal release of inert gases from (110) and (211) W surfaces

E. V. Kornelsen and M. K. Sinha (Radio \& Electr. Eng. Div., Nat. Res. Council, Ottawa, Can.)

J. Appl. Phys. 40 [7], 2888-94 (1969)

22. Influence of oxygen on $\mathrm{Zr}$ properties at high temperatures

I. I. Kornilov, V. V. Glazova and E. M. Kenina

At. Energ. (USSR) 26 [3], 324-27 (1969)

23. Determination of the spectral coefficients of the radiation of $\mathrm{Ta}-\mathrm{Nb}$ alloys

A. A. Kotlyar and Ts. V. Voskoboinik (Electr. Vac. Apparatus Plant)

High Temp. 6 [5], 794-96 (1968)

24. Experimental study of the effect of the similarity factor on the emissivity of metals

I. I. Kovalev, A. R. Gordon, F. M. Tartakovskaya and I. A. Melnikova High Temp. 6 [3], 419-23 (1968)

25. Rate of evaporation of certain carbide thermionic cathodes and evaluation of their operating temperatures

B. S. Kulvarskaya

Zh. Tekh. Fiz. $\underline{39}$ [4], 728-37 (1969)

26. Effect of Ti, S, and other elements on the eutectic solidification of $\mathrm{Fe}-\mathrm{C}-\mathrm{Si}$ alloys

B. Lux (Battelle Inst., Geneva, Switz.)

Mém. Sci. Rev. Mét. 66, 347 (1969)

27. A measurement of the anisotropy of the surface energy of pure $W$ with the field ion microscope

A. Müller and M. Drechsler (Fritz Haber Inst., Max Planck Ges., Berlin-Drahlem)

Surface Sci. 13 [3], 471-90 (1969)

28. Thermal conductivity, specific electrical resistivity, and total emissivity of refractory metals at high temperatures

B. E. Neimark and L. K. Voronin (Dzerzhinskii All-Union Inst. Heat Tech.)

High Temp. 6 [6], 999-1010 (1968)

29. Electrotransport of $\mathrm{C}, \mathrm{N}$ and $\mathrm{O}$ in lutetium

D. T. Peterson and F. A. Schmidt (Inst. Atomic Res. \& Met. Dept., Iowa State Univ., Ames, Iowa 50010)

J. Less-Common Metals 18 [2], 111-16 (1969) 
Ea. 30. Integral hemispherical emissivity and specific electrical resistance of $\mathrm{Ta}$ in the temperature interval $1200-2800 \mathrm{~K}$

V. A. Petrov, V. Ya. Chekhovskoi and A. E. Sheindlin (High Temp. Inst., Acad. Sci. USSR, Moscow)

High Temp. $\underline{6}[3], 525-26$ (1968)

31. Characteristics of a Cs thermoemission converter with a W cathode V. I. Petrov and A. P. Kovarenkov

High Temp. 6 [6], 1098-1100 (1968)

32. Relationship between the structure of Fe-C melts and the activity of their carbon

A. V. Reviakin and A. M. Samarin (Baikov Met. Inst., Moscow)

Dokl. Akad. Nauk SSSR $\underline{186}$ [6], 1371-74 (1969)

33. Further observations on positive ion emission from $W$

W. R. Rueth and D. Lichtman (Phys. Dept. and Lab. for Surface Studies, Univ. of Wisconsin, Milwaukee, Wisc. 53201)

Surface Sci. 12 [1], 96-101 (1968)

34. The formation and stability of group IV A carbides and nitrides in Mo

N. E. Ryan and J.W. Martin (Met. Dept., Univ. of Oxford, Engl.)

J. Less-Common Metals 17 [4], 363-76 (1969)

35. The activity of oxygen in Fe-C melts

A. M. Samarin, I. A. Tomilin and L. A. Schwarzman (Bardin Ferrous Met. Inst., Moscow)

Dok1. Akad. Nauk SSSR 186 [1], 146-50 (1969)

36. Thermal expansion of solid solutions of the system HfC-TaC

G. V. Samsonov, I. G. Barantseva and V. N. Paderno (Inst. Probl. Mater. Sci., Acad. Sci. Ukr. SSR)

High Temp. $\underline{6}$ [2], 241-43 (1968)

37. Work function of alloys in the Mo-Re system

E. M. Savitskii, I. V. Burov and L. N. Litvak

Zh. Tekh. Fiz. 39 [4], 713-15 (1969)

38. Output characteristics of a $\mathrm{Cs}$ diode with $\mathrm{ZrB}_{2}$ cathodes

A. T. Semenchenkov, A. N. Kobylkin, E. K. Osipov and O. S. Ivanov (Baikov Inst. Met., Acad. Sci. USSR)

High Temp. $\underline{6}$ [5], 790-93 (1968)

39. Thermodynamics of the solubility and permeation of hydrogen in metals at high temperature and low pressure

D. S. Shupe and R. E. Stickney (Mech. Eng. Dept., Mass. Inst. Tech., Cambridge, Mass. 02139)

J. Chem. Phys. 51 [4], 1620-25 (1969) 
Ea. 40. Optical constants of $\mathrm{Ta}-\mathrm{W}$ and $\mathrm{Nb}$-Mo alloys at high temperatures L. K. Thomas (Inst. Metallphys., Tech. Univ., Berlin 15, Germ.) Z. Angew. Phys. 27 [3], 209-13 (1969)

41. Thermal diffusivity and conductivity of $\mathrm{Ti}$ at high temperatures V. E. Zinovev, R. P. Krentsis and P. V. Geld (Ural Polytech. Inst.) High T:mP. $\underline{6}[5], 888-90$ (1968)

42. Temperature and heat conductivity of $\mathrm{Cr}$ at high temperatures V. E. Zinovev, G. P. Krentsis and P. V. Geld (Kirov Polytech. Inst., Sverdlovsk, USSR)

Fiz. Tverd. Tela 11 [7], 2012-14 (1969)

b. Non-metallic materials

1. Thermal diffusion in closed oxide fuel systems

E. A. Aitken (G. E. Vallecitos Nuc1. Ctr., Pleasanton, Calif. 94566)

J. Nuc1. Mater. $\underline{30}[1-2], 62-73$ (1969)

2. Volatilization characteristics of UN

C. A. Alexander, J. S. Ogden and W. M. Pardue (Battelle Memorial Inst., Columbus, Ohio)

J. Nuc1. Mater. 31 [1], 13-24 (1969)

3. The variation of $\mathrm{ZrO}_{2}$ structure at high temperatures in vacuum N. A. Andreeva, V. M. Gropianov and L. V. Kozlovski (Lensovet Tech. Inst., Leningrad, USSR)

Izv. Akad. Nauk SSSR, Neorg. Mater. 5 [7], 1302-03 (1969)

4. Investigation of vaporization of uranium carbide, nitride and carbonitrides

R. A. Andrievskii, V. V. Chromonozhkin, E. A. Galkin and V. I. Mitrofanov

At. Energ. (USSR) 26 [6], 494-98 (1969)

5. Irradiation testing (pulse conditions) of the ternary fuel system for the power burst facility

R. J. Beals and R. S. Kern (Power Burst Facility Reactor, Idaho Falls, Idaho 83401)

J. Am. Ceram. Soc. $\underline{52}$ [7], 355-58 (1969)

6. Measurement of the vapor pressures of the lanthanide oxides between 2000 and $2400{ }^{\circ} \mathrm{C}$

G. Benezech and M. Foex (Lab. Ultra-Réfract., 66-Odeillo, P.-0., Fr.)

C. R. Acad. Sci. 268C [26], 2315-18 (1969)

7. Fibrous refractory composites obtained by oriented crystallization in the systems $\mathrm{Co}-\mathrm{Cr}-\mathrm{Ta}-\mathrm{C}$ and $\mathrm{Ni}-\mathrm{Cr}-\mathrm{Ta}-\mathrm{C}$

H. Bib Ring, M. Rabinovitch and G. Seibel (ONERA, 92-Chatillon, Fr.) C. R. Acad. Sci. 268C, 1666 (1969) 
Eb. 8. Thermal dissociation of Zn-subgroup chalcogenides. I. Thermal dissociation of $\mathrm{ZnS}$ and $\mathrm{ZnSe}$

E. I. Boev, L. A. Benderskii and G. A. Milkov (All-Union Luminophores Inst., Moscow)

Zh. Fiz. Khim. 43 [6], 1393-97 (1969)

9. Creep of aluminosilicate refractories

L. B. Borovkova, E. S. Lukin and D. N. Poluboyarinov

Ogneupory $\underline{34}[7], 39-43$ (July 1969)

10. Initial sintering kinetics of $\mathrm{MgAl}_{2} \mathrm{O}_{4}$

R. J. Bratton (Westinghouse Res. Labs., Pittsburgh, Pa. 15235)

J. Am. Ceram. Soc. 52 [8], 417-19 (1969)

11. Static oxidation and compatibility of $B N$ and of $B N$ composite to $2000{ }^{\circ} \mathrm{C}$

J. D. Buckley (NASA Langley Res. Ctr., Hampton, Va.)

Am. Ceram. Soc. Bull. 48 [7], 711-15 (1969)

12. Study of the apparent viscosity and the flow of refractory $\mathrm{MgO}$ products

J. Dequenne (Inst. Nat. Silicates)

Silicates Ind. 34, 179 (1969)

13. Formation and stability of beta-alumina in alpha-alumina ceramics

J. H. Duncan and W. E. C. Creyke (Nelson Res. Labs., Engl. Electr. Co., Stafford, U. K.)

Trans. Brit. Ceram. Soc. 68, 137-44 (1969)

14. Effect of a temperature gradient on the stoichiometry of $\mathrm{UO}_{2}-\mathrm{PuO}_{2}$ fue 1

S. K. Evans, E. A. Aitken and C. N. Craig (G. E. Nucl. En. Div., Pleasanton, Calif. 94566)

J. Nucl. Mater. 30 [1-2], 57-61 (1969)

15. The anomalies of thermal and isomorphous deformations of the structure of baddeleyite (monoclinic $\mathrm{ZrO}_{2}$ )

S. K. Filatov and V. A. Frank-Kamenetskii (Leningrad State Univ., Leningrad $B-164$, USSR)

Acta Cryst. A25 [S3], S50 (1969)

16. High temperature studies of urania in a thermal gradient

R. E. Fryxell and E. A. Aitken (G. E. Nucl. Syst. Progr., Cincinnati, Ohio 45215)

J. Nucl. Mater. $\underline{30}[1-2], 50-56$ (1969)

17. Thermal expansion of $\mathrm{Y}$ and $\mathrm{Gd}-\mathrm{Fe}, \mathrm{Ga}$ and $\mathrm{Al}$ garnets

S. Geller, G. P. Espinosa and P. B. Crandall (North American Rockwell Co., Sci. Ctr., Thousand Oaks, Calif.)

J.Appl. Cryst. 2 [2], 86 (1969) 
Eb. 18. Mass spectrometric evidence for the gaseous AlOCN molecule

K. A. Gingerich (Chem. Dept., Texas A\&M Univ., College Station, Texas 77843)

J. Am. Chem. Soc. 91 [15], 4302-03 (1969)

19. Melting point of $\mathrm{Al}_{2} \mathrm{O}_{3}$ in air

W. Gorski and A. Dietzel (Max Planck Inst. Silicatforsch., 87-Wurzburg, Germ.)

Rev. Int. Hautes Tempér. Réfract. 6 [2], 105 (1969)

20. Effect of $\mathrm{Mn}, \mathrm{Fe}$ and $\mathrm{F}$ on the properties of tricalcium silicate W. Gutt and G. J. Osborne (Bldg. Res. Station, Watford, U. K.)

Trans. Brit. Ceram. Soc. 68, 129-36 (1969)

21. Hot-working of $\mathrm{Al}_{2} \mathrm{O}_{3}$. I. Primary recrystallization and texture A. H. Heuer, D. J. Sellers and W. H. Rhodes (Avco Corp., Appl. Tech. Div., Lowell, Mass. 01851)

J. Am. Ceram. Soc. $\underline{52}$ [9], 468-74 (1969)

22. Vapor formation kinetics of rare earth oxides in a direct current arc

A. V. Karyakin, N. V. Laktionova and L. I. Pavlenko

Zh. Prikl. Khim. 42 [4], 751-56 (1969)

23. Role of the $\mathrm{O} / \mathrm{U}$ ratio on the sintering of $\mathrm{UO}_{2}$

K. W. Lay and R. E. Carter (G. E. R/D Ctr., Schenectady, N. Y. 12301)

J. Nucl. Mater. $\underline{30}[1-2], 74-87$ (1969)

24. Nonequilibrium vaporization rates of single-crystal $\mathrm{ZnO}$ basal faces

R. B. Leonard and A. W. Searcy (Dept. Mater. Sci. Eng., Univ. of Calif., Berkeley, Calif.)

J. Chem. Phys. $\underline{50}$ [12], 5419-20 (1969)

25. Activation energy in sintering

C. S. Morgan (Oak Ridge Nat. Lab., Oak Ridge, Tenn. 37830)

J. Am. Ceram. Soc. 52 [8], 453-54 (1969)

26. Densification and wear resistance of ceramic systems. III. $\mathrm{TaN}-\mathrm{ZrB}_{2}$

Y. Murata and E. D. Whitney (Carborundum Co. R/D Div., Niagara Falls, N. Y.)

Am. Ceram. Soc. Bull. 48 [7], 698-702 (1969)

27. Resistance of alumina-based ceramics to the action of an electric arc plasma

K. K. Namitokov and V. V. Soloveva

Teplofiz. Vys. Temp. I [3], 520-23 (1969)

28. Thermal expansion of fused quartz

J. Oishi and T. Kimura (Aoyama Gakuin Univ., Tokyo)

Metrologia $\underline{5}[2], 50-55$ (1969) 
Eb. 29. Changes in the properties of an acetylene black on heat treatment A. Pacault and S. Flandrois (Ctr. Rec. Paul Pascal, Domaine Univ., 33-Talence, Fr.)

Rev. Chim. Minér. 6, 267 (1969)

30. Structure and properties of pyrolytic SiC

R. J. Price (Gulf Gen. Atomic Inc., John Jay Hopkins Lab., San Diego, Calif.)

Am. Ceram. Soc. Bull. 48 [9], 859-62 (1969)

31. Magnetic and structural properties of a pyrolytic carbon deposited at $1600{ }^{\circ} \mathrm{C}$

J. Prost and H. Gasparoux (Ctr. Rech. Paul Pascal, Domaine Univ., 33-Talence, Fr.)

Rev. Chim. Minér. 6, 275 (1969)

32. CaO. I. Fabrication and characterization

R. W. Rice (U. S. Naval Res. Lab., Washington, D. C. 20390)

J.Am. Ceram. Soc. $\underline{52}[8], 420-27$ (1969)

33. Evaporation rate and thermodynamic properties of titanium nitride E. A. Ryklis, A. S. Bolgar and V. V. Fesenko

Porosh. Met. 9 [6], 62-64 (June 1969)

34. Behavior of calcium aluminates during melting

B. Tavasci, A. Ghise IIi and G. Cancelli

Chim. Ind. (Milan) 51 [6], 607-09 (1969)

35. Microhardness of $\mathrm{TiO}_{2}-\mathrm{Nb}_{2} \mathrm{O}_{5}$ solid solutions

T. Y. Tien, J. J. Rosen, W. C. Bigelow and V. Sanvordenker (Chem. \& Met. Eng. Dept., Univ. of Michigan, Ann Arbor, Mich. 48104)

J. Am. Ceram. Soc. 52 [9], 520 (1969)

36. Refractory properties of a Florida kyanite-sillimanite concentrate R. R. Van Der Beck (M\&T Chemicals, Rahway, N. J.)

Am. Ceram. Soc. Bull. 48 [7], 703-06 (1969)

37. Heat transfer by radiation in polycrystalline corundum

I. I. Vishnevskii and V. N. Skripak

Teplofiz. Vys. Temp. 7 [3], 444-48 (1969)

38. Enthalpy and specific heat of the sesquioxides of La and Lu at high temperatures

T. S. Yashvili, D. Sh. Tsagareishvili and G. G. Gvelesiani (Met. Inst., Acad. Sci. Ge. SSR)

High Temp. 6 [5], 781-84 (1968)

39. Effect of oxidation on the emissivity of $\mathrm{MoSi}_{2}$ coatings

G. A. Zhorov and E. V. Sivakova

High Temp. 6 [6], 995-98 (1968) 
1. Effect of an oxide film on the emissivity of a metal

G. F. Muchnik, L. A. Gubkov and I. A. Salnikov

High Temp. 6 [2], 258-62 (1968)

\section{F. Properties, at temperatures above $1000{ }^{\circ} \mathrm{C}$, of materials which melt bel ow $1500^{\circ} \mathrm{C}$}

\section{a. Metallic materials}

1. Vapour pressures and thermodynamic behaviour of Cd-Sb alloys

E. H. Baker (Nuffield Res. Group, Met. Dept., Imperial College, London, SW 7)

Trans. Inst. Mining Met. 78C, 83-86 (1969)

2. Vaporization of $\mathrm{Sb}$ and $\mathrm{Te}$ in the vicinity of the critical point

V. S. Ban and B. E. Knox (Mater. Res. Lab., Pa. State Univ., Univ. Park, Pa. 16802)

J. Chem. Phys. 51 [2], 524-26 (1969)

3. Effect of some factors on oxygen concentration in molten steel

L. M. Efimov and A. V. Shemyakin

Izv. Vyssh. Ucheb. Zaved, Chern. Met. 12 [5], 39-42 (May 1969)

4. Some peculiarities of the electrical conductivity of the light rare-earth metals $\mathrm{La}, \mathrm{Ce}, \mathrm{Pr}$ and $\mathrm{Nd}$ in the solid and liquid states

F. Gaibullaev, A. R. Regel and Kh. Khusanov (Acad. Sci., Semicond. Inst., Leningrad, USSR)

Fiz. Tverd. Tela 11 [5], 1400-01 (1969)

5. Equilibrium vapor compositions and activities of components for $\mathrm{Fe}-\mathrm{Cr}-\mathrm{Ni}$ alloys at $1600{ }^{\circ} \mathrm{C}$

S. W. Gilby and G. R. St. Pierre (Met. Eng. Dept., Ohio State Univ., Columbus, Ohio)

Trans. Met. Soc. AIME 245 [8], 1749-58 (1969)

6. Gaseous metal silicides. I. Dissociation energy of the molecule AuSi

K. A. Gingerich (Chem. Dept., Texas A\&M Univ., College Station, Texas 77843)

J. Chem. Phys. 50 [12], 5426-28 (1969)

7. Exploding wire phenomena in the coinage metals

J. D. Graham, C. W. Spangler, S. K. Lott and M. J. Joncich (Chem. Dept., N. Illinois Univ., Dekalb, Ill.)

J. Phys. Chem. Solids 30, 1900-02 (1969)

8. High temperature $\mathrm{x}$-ray study of albite

H. D. Grundy and W. L. Brown (Geol. Dept., McMaster Univ., Hamilton, Ont., Can.)

Mineral. Mag. 37, 156-72 (1969) 
Fa. 9. The liberation of $\mathrm{CO}$ from solidifying steel J. E. Gruzleski, O. Knacke and M. J. Meixner

Trans. Met. Soc. AIME 245 [8], 1699-1701 (1969)

10. Developments in the processing of liquid steel

C. Holden (Round Oak Steel Works, Brierly Hill Lab., Staffs., U.K.)

J. Iron Steel Inst. (London) 207, 806-25 (1969)

11. Equations of state of solid and liquid metals at high temperatures B. N. Ivanov (Inst. High Temp., Acad. Sci. USSR, Moscow) High Temp. 6 [6], 976-83 (1968)

12. Viscosity of the liquid alkali metals $\mathrm{K}, \mathrm{Na}$ and $\mathrm{Li}$ at high temperatures (up to $1500{ }^{\circ} \mathrm{C}$ )

N. A. Kalakutskaya (Krzhizhanovskii Inst. Power Eng.)

High Temp. 6 [3], 436-40 (1968)

13. Effect of modifiers on the dislocation structure of molten iron silicide

N. S. Kreshchanovskii, M. F. Sidorenko and A. S. Trekalo

Izv. Vyssh. Ucheb. Zaved., Chern. Met. 12 [5], 123-26 (May 1969)

14. Density and surface ent gy polytherms of molten Al

E. S. Levin, G. D. Ayushina and P. V. Geld (Ural Polytech. Inst.) High Temp. 6 [3], 416-18 (1968)

15. Dissociation energy of $\mathrm{Fe}_{2}$

S. S. Lin and A. Kant (Army Mater. Mech. Res. Ctr., Watertown, Mass. 02172)

J. Phys. Chem. 73 [7], 2450-51 (1969)

16. Dynamic recrystallization in $\mathrm{Ni}$ and $\mathrm{Ni}-\mathrm{Fe}$ alloys during hightemperature deformation

M. J. Luton (Met. Eng. Dept., McGill Univ., Montreal, Can.) and C. M. Sellars (Met. Dept., Univ. of Sheffield, Engl.)

Acta Met. 17 [8], 1033-43 (1969)

17. Temperature dependence of the magnetic susceptibility of liquid Au-Co and Co-B alloys

A. Menth and B. G. Bagley (Bell Tel. Labs., Murray Hill, N. J. 07974)

App1. Phys. Letters 15 [2], 67-68 (1969)

18. The elimination of traces of $\mathrm{C}$ during the heat treatment of $\mathrm{Fe}$ under $\mathrm{H}_{2}$ and under He

B. Rondot, J. C. Durand and J. Montuelle (Ctr. Etudes Chim. Mét., 94-Vitry, Fr.)

C. R. Acad. Sci. 268C, 1502 (1969)

19. Experimental measurement of the pressure of saturated Li

E. E. Shpilrain and A. M. Belova (Inst. High Temp., Acad. Sci., USSR) High Temp. 6 [2], 330-31 (1969) 
Fa. 20. Vapor pressure and crystal structure of Cm metal

P. K. Smith, W. H. Hale and M. C. Thompson (duPont Savannah River Lab., Aiken, S. C. 29801)

J. Chem. Phys. 50 [12], 5066-76 (1969)

21. Deformation and dislocation dynamics in Si single crystals

T. A. Taylor (Stanford Univ., 1968)

Dissertation Abstr. 29B [11], 4202 (1968-69)

b. Non-metallic materials

1. Equilibrium content of hydrogen in a molten slag saturated with water vapor

V. I. Antonenko, V. A. Kozheurov and I. Yu. Pashkeev

Izv. Vyssh. Ucheb. Zaved., Chern. Met. 12 [5], 14-19 (May 1969)

2. Dissociation pressure of binary semiconducting compounds of the type $\mathrm{B}_{2}{ }^{3} \mathrm{C}_{3}{ }^{6}$

L. I. Berger and 5 others

Izv. Akad. Nauk SSSR, Neorg. Mater. $\underline{5}$ [5], 872-75 (1969)

3. Thermodynamic properties of $\mathrm{PbO}-\mathrm{SiO}_{2}$ slags by emf measurements

G. G. Charette and S. N. Flengas (Dept. Met. and Mater. Sci., Univ. Toronto, Ont., Can.)

Can. Met. Quart. 7 [4], 191-200 (1968)

4. Retrograde solubility of $\mathrm{PbS}, \mathrm{PbSe}$, and $\mathrm{PbTe}$

N. Chou, K. Komarek and E. Miller (School Sci. Eng., New York Univ., N. Y.)

Trans. Met. Soc. AIME 245 [7], 1553-60 (1969)

5. Thermal conductivity of $\mathrm{PbTe}, \mathrm{SnTe}$, and GeTe in the solid and liquid states

V. I. Fedorov and V. I. Machuev (Power Eng. Inst., Moscow)

Fiz. Tverd. Tela 11 [5], 1379-81 (1969)

6. Thermal conductivity of $\mathrm{Bi}_{2} \mathrm{Se}_{3}$ in the liquid phase

V. I. Fedorov, A. S. Okhotin and V. M. Glazov (Mowcow Power Inst.) High Temp. $\underline{6}[2], 244-46$ (1968)

7. Thermal properties of $\mathrm{BaCl}_{2}$ from 300 to $1350 \mathrm{~K}$

T. E. Gardner and A. R. Taylor, Jr. (Met. Res. Lab., Bur. Mines, Tuscaloosa, Ala. 35486)

J. Chem. Eng. Data 14 [3], 281-83 (1969)

8. The density of $\mathrm{Sb}$ chalcogenides in the solid and liquid states as dependent on temperature

V. M. Glazov, N. N. Glagoleva and S. B. Evgeniev (Steel \& Alloys Inst., Moscow)

Izv. Akad. Nauk SSSR, Neorg. Mater. 5 [7], 1181-84 (1969) 
Fb. 9. Physicochemical analysis of $\mathrm{Ag}-\mathrm{Te}$ and $\mathrm{Ag}$-Se binary liquid systems V. M. Glazov, N. M. Makhmudova and A. N. Krestovnikov (Steel \& Alloys Inst., Moscow)

Izv. Akad. Nauk SSSR, Neorg. Mater. $\underline{5}$ [7], 1185-89 (1969)

10. Dissociation energy and ionization potential of SiO

D. L. Hildenbrand (Adv. Res. Lab., McDonnell-Douglas Co., Huntington Beach, Calif. 92646) and E. Murad (A. F. Cambridge Res. Labs., Bedford, Mass. 01730)

J. Chem. Phys. 51 [2], 807-11 (1969)

11. A modernized impression-type viscosimeter of the Kluyev system an studying the viscosity of glasses of the system $\mathrm{K}_{2} \mathrm{O}-\mathrm{RO}-\mathrm{SiO}_{2}$

O. G. Ivanov, N. I. Tretyakova and O. V. Mazurin (Lensovet Tech. Inst., Leningrad, USSR)

Steklo Keram. [7], 42-44 (July 1969)

12. Calculation of the minimum pressure, $\mathrm{p}-\mathrm{T}$ diagrams, and solidus of $\mathrm{ZnTe}$

A. S. Jordon and R. R. Zupp (Bell Tel. Labs., Murray Hill, N. J. 07974)

J. Electrochem. Soc. 116 [9], 1264-68 (1969)

13. BaO glasses in high alumina ceramics

R. J. Miller and R. Russell, Jr. (Ceram. Eng. Dept., Ohio State Univ., Columbus, Ohio)

Am. Ceram. Soc. Bu1l. 48 [8], 786-90 (1969)

14. Structure and properties of glasses and glass-forming melts. I. Electrical conductivity of molten alkali borates and phosphates K. P. Müller (Inst. Steine u. Erden, Tech. Hochschule Clausthal, Germ.)

Glastech. Ber. 42, 1-9 (1969)

15. Physico-chemical properties of some silicate melts. I. Densities and conductivities. II. Thermodynamic properties

H. S. Ray (Indian Inst. Tech., Dept. Met. Eng., Kanpur, India) Indian J. Technol. 7 [6], 183-93 (1969)

16. Electrical conductivity and viscosity of molten CdGe phosphide A. P. Serednii and 6 others

Phys. Status Solidi 34 [2], 439-42 (1969)

17. Thermodynamic properties of $\mathrm{CsF}_{2}$ and $\mathrm{BaF}_{2}$ in the 400-1300 $\mathrm{K}$ range Z. Z. Shpilrain and D. N. Kagan

Teplofiz. Vys. Temp. $\underline{7}$ [3], 577-79 (1969)

18. Calorimetric study of the heat content of molten slags

S. E. Vaisburd, P. P. Evseev, I. N. Zedina and A. Ya。 Stomakh in Izv. Vyssh. Ucheb. Zaved., Chern. Met. 12 [5], 54-56 (May 1969) 
Fb. 19. Melting curve of diopside to 50 kilobars

D. W. Williams and G. C. Kennedy (Univ. California, Inst. Geophys., Los Angeles, Calif. 90024)

J. Geophys. Res. 74 [17], 4359-66 (1969)

20. Melting of a hydrous phase: phlogopite

H. S. Yoder, Jr. and I. Kushiro (Geophys. Lab., Carnegie Inst. Washington, D. C. 20008)

Am. J. Sci. (Schairer Vol.) 267A, 558-82 (1969)

21. Free energy and basicity of molten silicate solution

T. Yokokawa and K. Niwa (Hokkaido Univ., Fac. Sci., Dept. Chem., Sapporo, Japan)

Trans. Japan Inst. Metals 10 [2], 81-84 (1969)

c. Mixed materials

1. Activities of $\mathrm{O}$ in liquid $\mathrm{Cu}$ and its alloys with $\mathrm{Ag}$ and $\mathrm{Sn}$

R. J. Fruehan and F. D. Richardson (Met. Dept., Imperial College, Lond on SW 7)

Trans. Met. Soc. AIME 245 [8], 1721-26 (1969)

G. Phase equilibria above $1000^{\circ} \mathrm{C}$

1. Phase diagram and oxidizability of $\mathrm{Nb}-\mathrm{Mo}-\mathrm{Cr}$ alloys

A. S. Adamova and A. T. Grigorev

Izv. Akad. Nauk SSSR, Metal. [3], 176-80 (May-June 1969)

2. The $\mathrm{Nb}-\mathrm{Hf}$ system

G. K. Alekseenko and L. N. Aleksandrova

Izv. Akad. Nauk SSSR, Metal. [3], 170-72 (May-June 1969)

3. Phase equilibrium diagram of the $\mathrm{Cu}-\mathrm{Nb}$ system

C. Allibert, J. Driole and E. Bonnier (Lab. Thermodynam. et Physicochim. Mét., 38-Grenoble, Fr.)

C. R. Acad. Sci. 268C, 1579 (1969)

4. High temperature study of the ternary phase diagram $\mathrm{Cu}-\mathrm{Nb}-\mathrm{W}$

C. Allibert, J. Driole and E. Bonnier (Lab. Thermodynam. et Physicochim. Mét., 38-Grenoble, Fr.)

C. R. Acad. Sci. 268C, 2277 (1969)

5. Melting relations in the system jadeite-diopside at 30 and 40 kilobars

P. M. Bell and B. T. C. Davis (Geophys. Lab., Carnegie Inst. of Washingt on, D. C. 20008)

Am. J. Sci. (Schairer Vol.) 267A, 17-32 (1969)

6. The $\mathrm{KF}-\mathrm{CoF}_{2}$ system as a possible model of the BaO-TiO system

I. N. Belyaev and S. A. Shilov

Zh. Neorg. Khim. 14 [7], 1994-96 (1969) 
G. 7. Melting point maxima of ThC-ThN and of UC-UN solid solutions

R. Benz (Los Alamos Sci. Lab., Los Alamos, N. M. 87544)

J. Nuc1. Mater. 31 [1], 93-98 (1969)

8. Phase equilibria in the $\mathrm{Zn}-\mathrm{Cd}-\mathrm{P}$ system. II. The $\mathrm{Zn}-\mathrm{P}$ system J. Berak and Z. Pruchnik (Dept. Chem., Univ. of Wroclaw, Poland) Roczniki Chem. 43 [6], 1141-46 (1969)

9. The $\mathrm{PbTe}_{\mathrm{T}} \mathrm{I}_{4}$ system

L. G. Berg and T. I. Malkova

Izv. Vyssh. Ucheb. Zaved., Khim. Khim. Tekhnol. 12 [6], 691-93

10. Ternary system of sodium sulfate, metaphosphate and pyrophosphate A. G. Bergman and V.A. Matrosova

Zh. Neorg. Khim. 14 [6], 1669-71 (1969)

11. Phase relations in the system $\mathrm{Li}_{2} \mathrm{O} \cdot \mathrm{B}_{2} \mathrm{O}_{3}-\mathrm{B}_{2} \mathrm{O}_{3}-\mathrm{NiO}$

J. S. Berkes and W. B. White (Mater. Res. Lab., Pennsylvania State Univ., Univ. Park, Pa. 16802)

J.Am. Ceram. Soc. 52 [9], 481-84 (1969)

12. Temperature control and calibration in quench furnaces and some new temperature measurements in the system $\mathrm{CaO}-\mathrm{MgO}-\mathrm{Al}_{2} \mathrm{O}_{3}-\mathrm{SiO}_{2}$

G. M. Biggar and M. J. O'Hara (Edinburgh Univ., Grant Inst. Geol., Edinburgh 9, Scotland)

Minera I. Mag. 37 [285], 1-15 (1969)

13. The Mn-Ni constitution diagram

K. E. Biuplakis and E. Kneller (Max Planck Inst. Metallforsch., Stuttgart, Germ.)

Z. Metallk. 60, 433-38 (1969)

14. Solubility limits in the $\mathrm{MgO}^{-} \mathrm{Fe}_{2} \mathrm{O}_{3}$ system as determined by diffusion

S. L. Blank and J. A. Pask (Inorg. Mater. Res. Div., Lawrence Rad. Lab. \& Mater. Sci. and Eng. Dept., Univ. California, Berkeley, Calif. 94720)

J.Am. Ceram. Soc. 52 [8], 460-61 (1969)

15. The $\mathrm{SrO}-\mathrm{Fe}_{2} \mathrm{O}_{3}-\mathrm{O}_{2}$ system

C. Brisi and P. Rolando

Ann. Chim. (Rome) 59 [5], 385-99 (1969)

16. The $\mathrm{TaCr}_{2}-\mathrm{ZrCr}_{2}$ and $\mathrm{TaCr}_{2}-\mathrm{NbCr}_{2}$ sys tems

P. B. Budberg and S. P. Alisova

Izv. Akad. Nauk SSSR, Metal [3], $181-83$ (May-June 1969)

17. Investigation of the Zr-Fe-Al system

V. V. Burnashova and V. Ya. Markiv (State Univ., Lvov, UkSSR)

Dopovidi Akad. Nauk Ukr. RSR, Ser. A [4], 351-53 (1969) 
G. 18. Solubility of carbon in metals and alloys

B. P. Burylev (Met. Inst., Novokuznetsk, USSR)

Zh. Fiz. Khim. 43 [6], 1393-97 (1969)

19. Solid state phase relations in the quaternary system $\mathrm{CeO}_{z}-\mathrm{BaO}-$ $\mathrm{CaO}-\mathrm{SrO}$. The $\mathrm{CeO}_{2}-\mathrm{BaO}-\mathrm{SrO}$ system

A. Cocco and V. Longo (Univ. Degli Studi, Fac. Ing., Trieste, Italy) Ann. Chim. (Rome) 59 [6], 495-501 (1969)

20. Relation between the phases in the solid state systems $\mathrm{CeO}_{2}-\mathrm{MgO}-\mathrm{CaO}$, $\mathrm{CeO}_{2}-\mathrm{MgO}-\mathrm{BeO}, \mathrm{CeO}_{2}-\mathrm{MgO}-\mathrm{SrO}, \mathrm{CeO}_{2}-\mathrm{MgO}-\mathrm{BaO}$, and $\mathrm{CeO}_{2}-\mathrm{CaO}-\mathrm{BaO}$

A. Cocco and L. Podda

Ann. Chim. (Rome) 59 [5], 488-94 (1969)

21. Dissociation pressure of $B i$ in the system $B i-T h$

O. Dahlke, W. Gans, O. Knacke and F. Müller (Lehrstuh1. Met. Kernbrennstoffe u. Theoret. Hüttenk., Tech. Hochschule Aachen, Germ.)

Z. Metallk. 60, 465-68 (1969)

22. Data on the $\mathrm{V}-\mathrm{Ni}$ phase diagram between 0 and $40 \% \mathrm{Ni}$

M. Daire and M. Gerspacher (Lab. Chim. Gén., E.N.S.C.S., Strasbourg, Fr.)

J. Less-Common Metals 17 [3], 334-35 (1969)

23. $\mathrm{Pb}$ chalcogenide crystalline solutions: phase equilibria, mechanisms of phase separation and micro-indentation hardness studies

M. S. Darrow (Pennsylvania State Univ., 1968)

Dissertation Abstr. 29B [12], 4799 (1968-69)

24. The Fe-In system

C. Dasarathy (Brit. Steel Co. Res. Ctr., Port Talbot, Glam, G. B.) Trans. Met. Soc. AIME 245 [8], 1838-39 (1969)

25. New tetragonal compounds $\mathrm{Nb}_{2} \mathrm{Si}$ and $\mathrm{Ta}_{2} \mathrm{Si}$

D. K. Deardorff, R. E. Siemens, P. A. Romans and R. A. McCune (Met. Res. Ctr., Bur. of Mines, Albany, Oregon)

J. Less-Common Metals 18 [1], 11-26 (1969)

26. On the existence and structure of a new $\mathrm{M}_{4} \mathrm{O}_{12}$ compound in the systems $\mathrm{ZrO}_{2}-\mathrm{MgO}$ and $\mathrm{HfO}_{2}-\mathrm{MgO}$

C. Delamarre (Lab. Chim. Appl. Etat Solide, 94-Vitry, Fr.)

C. R. Acad. Sci. 269C, 113 (1969)

27. Recent study of the diagram $\mathrm{CaO}-\mathrm{Al}_{2} \mathrm{O}_{3}-\mathrm{Fe}_{2} \mathrm{O}_{3}-\mathrm{FeO}$

H. C. de Saint Chamant (Ctr. Rech. Jonchère, Ciments Lafarge, Fr.) Silicates Ind. 34, 151 (1969)

23. Critical evaluation of the literature data on beta alumina and related phases. I. Phase equilibria and characterization of beta alumina phases

R. C. DeVries and W. L. Roth (G. E. R/D Ctr., Schenectady, N.Y. 12301) J. Am. Ceram. Soc. $\underline{52}$ [7], 364-69 (1969) 
G. 29. Solid solubility of $\mathrm{CaF}_{2}$ in cryolite

E. W. Dewing (Alcan R/D, Arvida, Quebec, Can.)

Trans. Met. Soc. AIME 245 [8], 1829-30 (1969)

30. The systems $\mathrm{MF}_{2}-\mathrm{CrF}_{3}(\mathrm{M}=\mathrm{Ca}, \mathrm{Sr}, \mathrm{Ba})$

D. Dumora and J. Ravez (Fac. Sci. Bordeaux, 33-Talence, Fr.)

C. R. Acad. Sci. 268C, 1246 (1969)

31. Complete isothermal cross-section $\left(1100{ }^{\circ} \mathrm{C}\right.$ ) of the $\mathrm{Nd}_{2} \mathrm{O}_{3}-\mathrm{SrO}-\mathrm{B}_{2} \mathrm{O}_{3}$ system

B. F. Dzhurinski, I. V. Tananaev and 0. A. Aliev

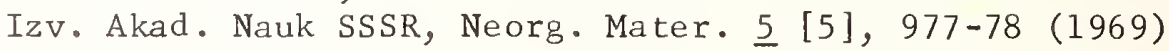

32. Phase equilibria in the Ti-Cu-Ag system at $700^{\circ}$

V. N. Eremenko, Yu. I. Buyanov and N. M. Panchenko

Izv. Akad. Nauk SSSR, Metal. [3], 188-92 (May-June 1969)

33. A new chi-phase in the Co-Cr-W-C system

P. Ettmayer and H. Seifarth (Inst. Chem. Tech. Anorg. Stoffe, Tecin. Hochschule Wien, Austria)

Monatsh. Chem. 100, 616-23 (1969)

34. Studies on stabilization of $\mathrm{UAl}_{3}$ in Al-rich nuclear fuels H. E. Exner and G. Petzow (Max Planck Inst. Metallforsch., Stuttgart, Germ.)

Metall 23, 220-25 (1969)

35. Alloys of noble metals with the most electropositive elements. Compounds of Li with $\mathrm{Pd}$ and $\mathrm{Pt}$

R. Ferro, R. Capelli, S. Delfino and G. Centineo

Atti Acad. Naz. Lincei, Rend., Cl. Sci. Fis. Mat. Natur. 45 [6], 564-66 (1968)

36. Alloys of noble metals with the most electropositive elements. Micrographic and x-ray examination of the Al-Ir system R. Ferro, R. Capelli, R. Marazza, S. Delfino and A. Borsese Atti Acad. Naz. Lincei, Rend., Cl. Sci. Fis. Mat. Natur., 45 [6], $556-63(1968)$

37. The $\mathrm{MnO}_{\mathrm{n}}-\mathrm{CaO}-\mathrm{P}_{2} \mathrm{O}_{5}$ constitution diagram in air at temperatures of 1510 to $1610{ }^{\circ} \mathrm{C}$

W. Fix., H. E. Wiemer and H. J. Tolkemit (Inst. Eisenhüttenw., Tech. Hochschule Clausthal, Germ.)

Arch. Eisenhüttenw. 40, 215-21 (1969)

38. Studies in the system $\mathrm{BaO}-\mathrm{Al}_{2} \mathrm{O}_{3}-\mathrm{SiO}_{2}$. II. The binary system celsian $\left(\mathrm{BaAl}_{2} \mathrm{Si}_{2} \mathrm{O}_{8}\right)$-silica $\left(\mathrm{SiO}_{2}\right)$

W. R. Foster and H. C. Lin (Mineral. Dept., Ohio State Univ., Columbus, Ohio 43210)

Am. J. Sci. (Schairer Vol.) 267A, 134-44 (1969) 
G. 39. Metal-metal carbide eutectic temperatures in the alloy systems $\mathrm{W}-\mathrm{Re}, \mathrm{W}-\mathrm{Mo}$ and Mo-Re

R. J. Fries, J. E. Cummings, C. G. Hoffman and S. A. Daily (Los Alamos Sci. Lab., Los Alamos, N. M. 87544)

J. Nucl. Mater. 31 [2], 230-32 (1969)

40. The system $\mathrm{Si}_{3} \mathrm{~N}_{4}-\mathrm{Sr}_{3} \mathrm{~N}_{2}$

J. Gaude and J. Lang (Fac. Sci., 35-Rennes, Fr.)

C. R. Acad. Sci. 268C, 1785 (1969)

41. Isobaric ternary phase diagrams for the Mo-C-0 system at $1600 \mathrm{~K}$ A. Ghosh (Met. Eng. Dept., Indian Inst. Tech., Kanpur, India)

J. Less-Common Metals 17 [3], 329-33 (1969)

42. $\mathrm{P}-\mathrm{T}-\mathrm{X}$ relations in the system $\mathrm{CaCO}_{3}-\mathrm{MgCO}_{3}$ at high temperatures and pressures

J. R. Goldsmith and R. C. Newton (Dept. Geophys. Sci., Univ. of Chicago, I11. 60637)

Am. J. Sci. (Schairer Vo1.) 267A, 160-90 (1969)

43. The polytypism of silicon carbide

A. H. Gomes de Mesquita (Philips Res. Lab., Eindhoven, Netherlands)

Philips Tech. Rev. 30 [2], 36-47 (1969)

44. A study of the sellaite-kotoite binary section of the $\mathrm{MgO}-\mathrm{MgF}_{2}-\mathrm{B}_{2} \mathrm{O}_{3}$ system

A. P. Grigoriev and A. A. Brovkin (Acad. Sci., Geol. Inst., Yakutsk, USSR)

Dokl. Akad. Nauk SSSR 186 [6], 1387-90 (1969)

45. Generation of chemical potentials by analysis of phase diagrams

R. Hiskes (Stanford Univ., 1968)

Dissertation Abstr. 29B [11], 4198 (1968-69)

46. Phase equilibria in the $\mathrm{HfO}_{2}-\mathrm{Sc}_{2} \mathrm{O}_{3}$ system

G. A. Kalinovskaya, F. M. Spiridonov and L. N. Komissarova (Moscow State Univ., Inorg. Chem. Dept., V-234 Moscow)

J. Less-Common Metals 17 [2], 151-59 (1969)

47. Phase diagram of the Ge-Te system

S. G. Karbanov, V. P. Zlomanov and A. V. Novoselova (Lomonosov State Univ., Moscow)

Izv. Akad. Nauk SSSR, Neorg. Mater. 5 [7], 1171-74 (1969)

48. X-ray study of the Hf-Si system (37-65 atomic pct Si)

O. G. Karpinskii and B. A. Evseev

Izv. Akad. Nauk SSSR, Meta1. [3], 166-69 (May-June 1969)

49. Comments on effects of pressure on the phase equilibria and transformations in the $\mathrm{Fe}-\mathrm{Cr}$ system

L. Kaufman (ManLabs Inc., Cambridge, Mass. 02139)

Scripta Met. 3 [7], 435-38 (1969) 
G. 50. The system Ag-Sb-S from 600 to $200{ }^{\circ} \mathrm{C}$

C. W. Keighin and R. M. Hones (North. Illinois Univ., Geol. Div., Deka1b, I11. 60115)

Mineral. Deposita 4 [2], 153-71 (1969)

51. The $\mathrm{PbS}-\mathrm{Cu}_{2} \mathrm{~S}-\mathrm{FeS}-\mathrm{Na}_{2} \mathrm{~S}$ sys tem

N. I. Kopylov

Zh. Neorg. Khim. 14 [6], 1702-03 (1969)

52. A thermochemical investigation of the $\mathrm{Zr}-0$ system

A. N. Kornilov, I. M. Ushakov, S. M. Skuratov and G. P. Shveikin (Lomonosov State Univ., Moscow)

Dokl. Akad. Nauk SSSR 186 [4], 831-34 (1969)

53. Reactions in the Au-Cd-Hg system

L. F. Kozin, G. F. Cherkasova and M. I. Erdenbaeva

Izv. Akad. Nauk Kaz. SSR, Ser. Khim. 19 [3], 42-49 (1969)

54. Thermodynamics of equilibrium in the B-Cl-H system

V. A. Krenev and V. I. Evdokimov

Zh. Neorg. Khim. 14 [7], 1966-70 (1969)

55. Equilibrium diagrams of the $\mathrm{Zn}\left(\mathrm{PO}_{3}\right)_{2}-\mathrm{Na}_{2} \mathrm{O}, \mathrm{Zn}\left(\mathrm{PO}_{3}\right)_{2}-\mathrm{K}_{2} \mathrm{O}$ and $\mathrm{KPO}_{3}-\mathrm{ZnO}$ systems

E. L. Krivovyazov, N. K. Voskresenskaya and K. K. Palkina (Kurnakov Gen. \& Inorg. Chem. Inst., Moscow)

Izv. Akad. Nauk SSSR, Neorg. Mater. 5 [6], 1057-61 (1969)

56. The $\mathrm{Pb}-\mathrm{S}$ system

G. Kullerud (Geophys. Lab., Carnegie Inst., Washington, D. C. 20008)

Am. J. Sci. (Schairer Vol.) 267A, 233-56 (1969)

57. The system forsterite-diopside-silica with and without water at high pressures

I. Kushiro (Geophys. Lab., Carnegie Inst., Washington, D. C. 20008)

Am. J. Sci. (Schairer Vol.) 267A, 269-94 (1969)

58. The $\mathrm{Gd}=\mathrm{H}_{2}$ system at elevated temperatures. Vacancy interactions in $\mathrm{GdH}_{2}$

G. G. Libowitz and J. G. Pack (Ledgemont Lab., Kennecott Copper Co., Lexington, Mass. 02173)

J. Phys. Chem. 73 [7], 2352-56 (1969)

59. The system $\mathrm{CaF}_{2}-\mathrm{CaMgSi}_{2} \mathrm{O}_{6}$

S. B. Lin and B. J. Burley (Geol. Dept., McMaster Univ., Hamilton, Ont., Can.)

Can. J. Earth Sci. 6 [2], 269-80 (1969) 
G. 60. Subsolidus relations along the join hedenbergite-ferrosilite

D. H. Lindsley and J. L. Munoz (Geophys. Lab., Carnegie Inst., Washington, D. C. 20008)

Am. J. Sci. (Schairer Vol.) 267A, 295-324 (1969)

61. Solubility of $\mathrm{H}_{2}$ in alloys of $\mathrm{Ni}$ with $\mathrm{Fe}$ and $\mathrm{Co}$

T. V. Lipets, Zh. L. Vert and I. P. Tverdovskii (State Appl. Chem. Inst., Moscow)

Zh. Fiz. Khim. 43 [5], 1331-32 (1969)

62. The alkali-rich region of the system $\mathrm{Na}_{2} \mathrm{O}-\mathrm{SiO}_{2}$

J. Löffler

Glastech. Ber. 42, 92-96 (1969)

63. Solid state phase relations in the quaternary system $\mathrm{CeO}_{2}-\mathrm{BaO}-\mathrm{CaO}-$ $\mathrm{SrO}$. The $\mathrm{CeO}_{2}-\mathrm{CaO}-\mathrm{SrO}$ system

V. Longo and M. D. Mastromonaco (Univ. Degli Studi, Fac. Ing., Trieste, Italy)

Ann. Chim. (Rome) 59 [6], 502-09 (1969)

64. On formation of new phases in the systems SrO-Sm, Gd and Dy oxides

L. M. Lopato and A. E. Kushchevsky (Acad. Sci., Mat. Tech. Inst., Kiev, UkSSR)

Dopovidi Akad. Nauk Ukr. RSR, Ser. B [7], 637-39 (1969)

65. New compounds in the systems of $\mathrm{Pr}_{2} \mathrm{O}_{3}-\mathrm{SrO}$ and $\mathrm{Nd}_{2} \mathrm{O}_{3}-\mathrm{SrO}$

L. M. Lopato, V. N. Pavlikov and L. I. Lugin (Acad. Sci., Mat. Tech. Inst., Kiev, UkSSR)

Dopovidi Akad. Nauk Ukr. RSR, Ser. B [5], 428-31 (1969)

66. The systems $\mathrm{NaAlSi}_{3} \mathrm{O}_{8}-\mathrm{SiO}_{2}$ and $\mathrm{KAlSi}_{3} \mathrm{O}_{8}-\mathrm{SiO}_{2}$ to $20 \mathrm{~kb}$ and the relationship between $\mathrm{H}_{2} \mathrm{O}$ content, $\mathrm{P}\left(\mathrm{H}_{2} \mathrm{O}\right)$ and $\mathrm{P}$ (total) in granitic magmas

W. C. Luth (Geol. Dept., Stanford Univ., Stanford, Calif. 94305)

Am. J. Sci. (Schairer Vol.) 267A, 325-41 (1969)

67. The system $\mathrm{MgO}-\mathrm{SiO}_{2}-\mathrm{TiO}_{z}$ and its bearing on the distribution of $\mathrm{TiO}_{2}$ in basalts

I. D. MacGregor (Southwest Ctr. Adv. Studies., Dallas, Texas 75230)

Am. J. Sci. (Schairer Vol.) 267A, 342-63 (1969)

68. Glass formation in the system $\mathrm{Cs}_{2} \mathrm{O}-\mathrm{Nb}_{2} \mathrm{O}_{5}$

H. Marfels (Max Planck Inst. Silikatforsch., Würzburg, Germ.)

Naturwiss. 56, 283 (1969)

69. Glasses and crystalline compounds in the systems $\mathrm{Rb}_{\mathfrak{Z}} \mathrm{O}-\mathrm{TiO}_{2}$ and $\mathrm{Cs}_{2} \mathrm{O}-\mathrm{TiO}_{2}$

H. Marfels (Max Planck Inst. Silikatforsch., Würzburg, Germ.)

Glastech. Ber. 42, 161-76 (1969) 
G. 70. New ternary compounds in the systems ( $\mathrm{Sc}, \mathrm{Ti}, \mathrm{Zr}, \mathrm{Hf})-(\mathrm{V}, \mathrm{Cr}, \mathrm{Mn}, \mathrm{Fe}, \mathrm{Co}$, $\mathrm{NiCu})-(\mathrm{Al}, \mathrm{Ga})$

V. Ya. Markiv and V. V. Burnashova (State Univ., Lvov, UkSSR)

Dopovidi Akad. Nauk Ukr. RSR, Ser. A [5], 463-64 (1969)

71. Study of the phases $V_{x} O$, with $x \approx 1$

P. Massard, J. C. Bernier and A. Michel (Fac. Sci. Orsay, 91-Orsay, Fr.)

Ann. Chim. (Paris) 4, 147 (1969)

72. An investigation of the $W-S i$ system

V. A. Maximov and F. I. Shamrai (Baikov Met. Inst., Moscow)

Izv. Akad. Nauk SSSR, Neorg. Mater. 5 [6], 1136-37 (1969)

73. Phase equilibria in the $1375{ }^{\circ} \mathrm{C}$ isotherm of the system Sr-Ti-0

G. J. McCarthy, W. B. White and R. Roy (Mater. Res. Lab.,

Pennsylvania State Univ., Univ. Park, Pa. 16802)

J. Am. Ceram. Soc. 52 [9], 463-67 (1969)

74. Modified spinel $\beta-\mathrm{Mn}_{2} \mathrm{GeO}_{4}$ : stability and crystal structure

N. Morimoto, S. Akimoto and K. Koto (Inst. Sci. Ind. Res., Osaka

Univ., and Inst. Solid State Phys., Univ. of Tokyo)

Science 165 [3893], 586-88 (1969)

75. Investigations in the system $\mathrm{PbO}-\mathrm{SiO}_{2}-\mathrm{GeO}_{2}$

M. Mydlar, H. Nowotny and K. J. Seifert (Inst. Phys. Chem., Univ. Wien, Austria)

Monatsh. Chem. 100, 191-202 (1969)

76. Phase diagram of Fe-Sc alloys

O. P. Naumakin, V. F. Terekhova and E. M. Savitskii

Izv. Akad. Nauk SSSR, Metal. [3], 161-65 (May-June 1969)

77. The system Sro-"chromium oxide" in air and oxygen

T. Negas and R. S. Roth (Nat. Bur. Stds., Washington, D. C. 20234)

J. Res. Nat. Bur, Std. 73A [4], 431-42 (1969)

78. Structural diagram of the Al-B system

V. A. Neronov

Zh. Neorg. Khim. 14 [6], 1704-05 (1969)

79. Diopside + spinel equilibria, anorthite and forsterite reaction relationships in silica-poor 1 iquids in the system $\mathrm{CaO}-\mathrm{MgO}-$ $\mathrm{Al}_{2} \mathrm{O}_{3}-\mathrm{SiO}_{2}$ at atmospheric pressure and their bearing on the genesis of melilitites and nephelinites

M. J. O'Hara and G. M. Biggar (Grant Inst. Geol., Univ. of Edinburgh, Scotland)

Am. J. Sci. (Schairer Vol.) 267A, 364-90 (1969)

80. Phase diagram of GaAs-GaP quasi-binary system

K. Osamura and Y. Murakami (Kyoto Univ., Dept. Met., Kyoto, Japan) Japan. J. App1. Phys. $\underline{8}$ [7], 967 (1969) 
G. 81. Interaction of boron carbonitride with refractory metals and compounds

I. S. Oshchipko and A. I. Burykina

Porosh. Met. $\underline{9}$ [6], 87-90 (June 1969)

82. Certain features of high-temperature phase transitions in rareearth metal dicarbides

I. B. Paderno, V. L. Yupko and G. N. Makarenko

Izv. Akad. Nauk SSSR, Neorg. Mater. $\underline{5}$ [5], 889-93 (1969)

83. Solubility of $\mathrm{Nd}$ and Al in solid Mg

E. M. Padezhnova

Izv. Akad. Nauk SSSR, Meta1. [3], 196-200 (May-June 1969)

84. Reply to comments on effects of pressure on phase equilibria and transformation in the $\mathrm{Fe}-\mathrm{Cr}$ system

J. S. Pascover and S. V. Radcliffe (Continental Can Co., Corporate Res. Dept., Chicago, Ill.)

Scripta Met. $\underline{3}$ [7], 439-40 (1969)

85. Melting equilibria of the system $\mathrm{UAl}_{2}-\mathrm{Al}_{8} \mathrm{MO}_{3}-\mathrm{Mo}$

G. Petzow and J. Rexer (Max Planck Inst. Metallforsch., Stuttgart, Germ.)

Z. Metallk. 60, 449-53 (1969)

86. Thermodynamic studies on binary systems having strong tendency to demixing

B. Predel and H. Sandig (Inst. Metallforsch., Univ. Münster/ Westfalen, Germ.)

Z. Metallk. 60, 208-14 (1969)

87. New phases formed by the lanthanide oxides with SrO

F. Queyroux (Lab. Chim. Appl. Etat Solide, 94-Vitry, Fr.)

Rev. Int. Hautes Tempér Réfract. 6, 111 (1969)

88. The binary system $\mathrm{CaO}-\mathrm{Ta}_{2} \mathrm{O}_{\overline{8}}$

D. A. Reeve (Mines Branch, Dept. of Energy, Mines and Resources, Ottawa, Ont., Can.)

J. Less-Common Metals 17 [2], 215-22 (1969)

89. Phase relations in the system $\mathrm{CaO}-\mathrm{Ta}_{2} \mathrm{O}_{\overline{5}}-\mathrm{SiO}_{2}$

D. A. Reeve and N. F. H. Bright (Mines Branch, Dept. of Energy, Mines and Resources, Ottawa, Ont., Can.)

J. Am. Ceram. Soc. $\underline{52}$ [8], 405-09 (1969)

90. The Ge-Se phase diagram

L. Ross and M. Bourgon (Chem. Dept., Univ. of Montreal, Que., Can.) Can. J. Chem. 47 [14], 2555-60 (1969) 
G. 91. Position of the eutectic point on phase diagrams of binary systems I. V. Salli, O. I. Fomichev and G. A. Sakhno

Izv. Akad. Nauk SSSR, Metal. [3], 193-95 (May-June 1969)

92. Investigation of the $\mathrm{In}_{2} \mathrm{~S}_{3}-\mathrm{GeS}_{2}$ system

E. S. Sarkisov and R. A. Lidin

Izv. Akad. Nauk SSSR, Neorg. Mater. $\underline{5}$ [5], 985-86 (1969)

93. Glass formation in the system $\mathrm{SiO}_{2}-\mathrm{Al}_{2} \mathrm{O}_{3}-\mathrm{Fe}_{2} \mathrm{O}_{3}-\mathrm{MgO}-\mathrm{CaO}-\mathrm{MnO}-$ rare earth oxide

A. V. Sarukhanishvili and N. K. Kutateladze

Soobshch. Akad. Nauk Gruz. SSR 54 [1], 105-08 (1969)

94. The system $\mathrm{CaO}-\mathrm{MgO}-\mathrm{CaF}_{2}$

E. Schlegel (Inst. Silikathüttenk., Bergakad. Freiberg, Germ.) Silikattech. 20, 93-95 (1969)

95. The constitutional diagram $\mathrm{Mn}_{3} \mathrm{O}_{4}-\mathrm{MnO}$ and the dissociation pressures occurring in this system

N. G. Schmahl and D. F. K. Hennings (Inst. Phys. Chem., Univ. Saarbrücken, Germ.)

Arch. Eisenhütenw. 40, 395-99 (1969)

96. Decomposition equilibria in the $\mathrm{Fe}_{2} \mathrm{O}_{3}-\mathrm{Fe}_{3} \mathrm{O}_{4}$ system

N. G. Schmah1, D. Hennings and C. Rübelt (Inst. Phys. Chem., Univ. Saarbrücken, Germ.)

Arch. Eisenhüttenw. 40, 375-79 (1969)

97. The Y-Bi alloy system

F. A. Schmidt, O. D. McMasters and R. R. Lichtenberg (Inst. Atomic Res. and Met. Dept., Iowa State Univ., Ames, Iowa 50010)

J. Less-Common Metals 18 [3], 215-20 (1969)

98. The BaO-Pt system in air

S. J. Schneider and C. L. McDaniel (Nat. Bur. Stds., Washington, D. C. 20234)

J.Am. Ceram. Soc. $\underline{52}$ [9], 518-19 (1969)

99. High-pressure phases in the system $\mathrm{MgO}-\mathrm{Al}_{2} \mathrm{O}_{3}-\mathrm{SiO}_{2}-\mathrm{H}_{2} \mathrm{O}$

W. Schreyer and F. Seifert (Inst. Mineral., Ruhr-Univ., Bochum, Germ.)

Am. J. Sci. (Schairer Vol.) 267A, 407-43 (1969)

100. Solid state equilibria in the Fe-Mn-W-O system

H. Schröcke (Inst. Krist. Minera1., Univ. München, Germ.)

Neues Yahrb. Minera1., Abhand1. 110, 115-26 (1969)

101. Crystallochemical conversions during dissociation of spinel solid solutions in the $\mathrm{Mg}-\mathrm{Ti}-\mathrm{Fe}-\mathrm{O}$ system at equilibrium conditions

A. A. Shchepetkin, V. K. Antonov, V. I. Dvinin and G. I. Chufarov (Acad. Sci., Met. Inst., Sverdlovsk, USSR)

Zh. Neorg. Khim. 14 [7], 1760-64 (1969) 
G. 102. The La-Rh system

P. P. Singh and A. Raman (Eng. Mechan. Dept., Louisiana State Univ., Baton Rouge, La.)

Trans. Met. Soc. AIME 245 [7], 1561-68 (1969)

103. Solid solution of $\mathrm{Al}_{2} \mathrm{O}_{3}$ in rutile $\mathrm{TiO}_{2}$

R. A. Slepetys and P. A. Vaughan (Chem. Dept., Rutgers Univ., New Brunswick, N. J.)

J. Phys. Chem. 73 [7], 2157-62 (1969)

104. The system NiO-CaO

D. E. Smith, T. Y. Tien and L. H. Van Vlack (Chem. \& Met. Eng. Dept., Univ. of Michigan, Ann Arbor, Mich. 48104)

J. Am. Ceram. Soc. 52 [8], 459-60 (1969)

105. Reaction of rare earth oxides with $\mathrm{Na}_{2} \mathrm{O}$

V. I. Spitsyn, I. A. Muraveva, L. M. Kovba and I. I. Korchak

Zh. Neorg. Khim. 14 [6], 1451-55 (1969)

106. The $\mathrm{FeCl}_{2}-\mathrm{CrCl}_{2}$ system

A. A. Soloshenko and Ya. E. Vilnyanskii

Zh. Neorg. Khim. 14 [7], 1993-94 (1969)

107. Investigations in the system $\mathrm{BaO} \cdot \mathrm{Fe}_{2} \mathrm{O}_{3}-\mathrm{Fe}_{2} \mathrm{O}_{3}$

H. Stäblein and W. May (F. Krupp GmbH, Zentralinst. Forschung u.

Entwicklung, Essen, Germ.)

Ber. Deut. Keram. Ges. 46, 126-28 (1969)

108. The $\mathrm{Ni}$ corner in the $\mathrm{Ni}-\mathrm{Ga}-\mathrm{B}$ system

H. H. Stadelmaier and M. L. Fiedler (Eng. Res. Dept., North Carolina State Univ., Raleigh, N. C.)

Z. Metallk. 60, 447-48 (1969)

109. The ternary $\mathrm{CaCu}_{5}$-type borides $\mathrm{HfCo}_{3} \mathrm{~B}_{2}$ and $\mathrm{ZrCo}_{3} \mathrm{~B}_{2}$

H. H. Stadelmaier and J. D. Schöbel (Eng. Res. Dept., North Carolina State Univ., Raleigh, N. C.)

Monatsh. Chem. 100, 224-30 (1969)

110. Diagram of states of the system $\mathrm{Cr}-\mathrm{Ce}$

V. N. Svechnikov, G. F. Kobzenko, V. G. Ivanchenko and E. L.

Martynchuk (Acad. Sci., Metallophys. Inst., Kiev, UkSSR)

Dopovidi Akad. Nauk Ukr. RSR, Ser. A [4], 354-55 (1969)

111. Solubility of $\mathrm{N}_{2}$ in $\mathrm{Fe}-\mathrm{C}$ melts

A. G. Svyazhin, G. M. Chursin, A. F. Vishkarev and V. I. Yavoiskii

Izv. Vyssh. Ucheb. Zaved., Chern. Met. 12 [5], 43-46 (May 1969)

112. Phase diagram of the $\mathrm{Rb}-\mathrm{Rb}_{2} \mathrm{O}$ system: $\mathrm{Rb}$ suboxide $\mathrm{Rb}_{3} \mathrm{O}$

Ph. Touzain (Chem. Dept., Univ. of Montreal, Que., Can.)

Can. J. Chem. 47 [14], 2639-44 (1969) 
G. 113. Interaction of components in $\mathrm{Ni}-\mathrm{Zr}-\mathrm{N}$ melts

A. I. Trupolitov, O. N. Kryuchkov, A. Y. Stomakhin and A. F. Filippov

Izv. Vyssh. Ucheb. Zaved., Chern. Met. 12 [5], 57-61 (May 1969)

114. Phase diagram of the $\mathrm{NiCl}_{2}-\mathrm{CaCl}_{2}$ system

L. Sh. Tsemekhman, M. A. Nemoitin and S. E. Vaisburd

Zh. Prikl. Khim. 42 [6], 1402-03 (1969)

115. The system $\mathrm{Mn}-\mathrm{Ge}$

E. Wachtel and E. Th. Henig (Max Planck Inst. Metallforsch., Stuttgart, Germ.)

Z. Metal1k. 60, 243-47 (1969)

116. Phase transformation of $A 1 B_{10}$

G. Wil1 (Eduard Zint1 Inst., Tech. Hochschule Darmstadt, Germ.)

Z. Krist. 128, 156-58 (1969)

117. Phase equilibria in the system MgO-iron oxide- $\mathrm{TiO}_{2}$ in air

E. Woermann, B. Brezny and A. Muan (College of Earth \& Miner. Sci., Pa. State Univ., Univ. Park, Pa.)

Am. J. Sci. (Schairer Vol.) 267A, 463-79 (1969)

118. The fayalite-magnetite-quartz assemblage between 600 and $800{ }^{\circ} \mathrm{C}$

D. R. Wones and M. C. Gilbert (Geol. Survey and Geophys. Lab., Washington, D. C.)

Am. J. Sci. (Schairer Vol.) 267A, 480-88 (1969)

119. Diagram of "oxygen pressure-composition" in the Cu-Fe-0 system at $1000{ }^{\circ} \mathrm{C}$

A. G. Zalazinskii, V. F. Balakirev and G. I. Chufarov (Acad. Sci., Met. Inst., Sverdlovsk, USSR)

Zh. Fiz. Khim. 43 [6], 1636-37 (1969)

120. X-ray structural studies of alloys forming in the La-Cu-Al system

O. S. Zarechnyuk, E. I. Emes-Misenko, A. N. Malinkovich and

V. V. Gabrusevich

Izv. Akad. Nauk SSSR, Metal. [3], 173-75 (May-June 1969)

H. Reactions at temperatures above $1000{ }^{\circ} \mathrm{C}$

1. Growth of uncommon Verneuil crystals and their characterization by light scattering

J. A. Adamski, R. C. Powe11 and J. L. Sampson (A. F. Cambridge Res. Lab., Bedford, Mass. 01730)

J. Crystal Growth 3-4, 246-49 (1968)

2. The growth of mixed oxide crystals from the melt

F. W. Ainger and W. P. Bickley (Allen Clark Res. Ctr., Plessey Co., Caswe11, Towcester, Northants., Eng1.)

J. Crystal Growth 3-4, 278 (1968) 
H. 3. Growth of diamond seed crystals from the vapour at sub-atmospheric pressure

J. C. Angus, H. A. Will and W. S. Stanko (Case Western Reserve Univ., Cleveland, Ohio)

J. Crystal Growth 3-4, 172 (1968)

4. Interdiffusion in $\mathrm{NiO}, \mathrm{CaO}$ and $\mathrm{MgO}$ single crystals

M. Appel (Univ. of Calif., Berkeley, 1968)

Dissertation Abstr. 29B [12], 4634 (1968-69)

5. Kinetics of the growth of Mo, $W$ and Re borides from BN-metal powder mixtures

F. D. Baehren, F. Thümmler and D. Vollath (Inst. Mater. u. Festkörperforsch., Kernforschungszentr. u. Lehrstuhl Werkstoffk. II, T. H. Karlsruhe, Germ.)

J. Less-Common Metals 18 [3], 295-303 (1969)

6. Interpretation of kinetic data for the decarburization of iron droplets

L. A. Baker (Univ. of New South Wales, Australia)

Can. Met. Quart. I [4], 217-21 (1968)

7. Growth and properties of cadmium mercury telluride crystals

B. E. Bartlett, J. Deans and P. C. Ellen (Mullard Works, Southampton, Hants., Engl.)

J. Crystal Growth $\underline{3-4}, 276$ (1968)

8. Pulling of GaP crystals by liquid encapsulation

S. J. Bass and P. E. Oliver (Services Electron. Res. Lab., Baldock, Herts., Eng 1.)

J. Crystal Growth $\underline{3-4}$, 286-90 (1968)

9. The growing of single cadmium selenide crystals with hole conductance

R. V. Baubinas, I. I. Vaitkus and I. K. Vishchakas (Kapsukas State Univ., Vilnius, LiSSR)

Izv. Akad. Nauk SSSR, Neorg. Mater. $\underline{5}$ [6], 1000-04 (1969)

10. Oxygen and uranium diffusion in $\mathrm{UO}_{2}$

J. Belle (Bettis At. Power Lab., West Miflin, Pa. 15122)

J. Nucl. Mater. 30 [1-2], 3-15 (1969)

11. Seeded growth of garnet from molten salts

G. A. Bennet (Electr. Eng. Dept., Univ. of Glasgow, Engl.)

J. Crystal Growth 3-4, 458-62 (1968)

12. Steam oxidation kinetics and oxygen diffusion in $\mathrm{UO}_{z}$ at high temperatures

J. T. Bittel, L. H. Sjodahl and J. F. White (G. E. Missile \& Space Div., Cincinnati, Ohio 45215)

J. Am. Ceram. Soc. $\underline{52}[8], 446-51$ (1969) 
H. 13. Growth kinetics of thread-like sapphire crystals

S. Z. Bokshtein, L. K. Kalashnikov, S. Kishkin, M. P. Nazarova and

I. L. Svetlov

Fiz. Tverd. Tela 11 [6], 1627-32 (1969)

14. Correlation of experimental data to determine slag-metal equilibria

A. R. Booth and J. A. Charles (Met. Dept., Univ. of Cambridge, U.K.)

Trans. Inst. Mining Met. 78C, 115-16 (1969)

15. Destruction of carbides and their compositions at high temperatures in a flow of chemically active gases

T. A. Bovina

Inzh. -Fiz. Zh. 16 [6], 1068-72 (1969)

16. Growth of CaTisios by the Czochralski method

W. S. Brower and C. R. Robbins (Nat. Bur. Standards, Washington, D. C. 20234)

J. Crystal Growth $\underline{5}[4], 233-34$ (1969)

17. A cathode assembly for feeding powders into the plasma of expanded D.C. arcs

J. W. Bryant, J. M. Cox and D. Whyman (Nat. Phys. Lab., Teddington, U. K.)

J. Sci. Instr. 2 , 779-81 (1969)

18. Purification and the growth of Gd crystals

F. J. Cadieu and D. H. Douglass, Jr. (Phys. Dept., Univ. of Chicago, Ill. 60637)

J.Appl. Phys. 40 [6], 2376-77 (1969)

19. The reaction of $\mathrm{Cr}$ with $\mathrm{O}_{2}$ at elevated temperatures

L. Cadiou and J. Paidassi (C.E.N. Saclay, 91-Gif sur Yvette, Fr.)

Mém. Sci. Rev. Mét. 66, 217 (1969)

20. Growth of oriented $\mathrm{Ni}$ bicrystals by an electron beam floating zone technique

R. F. Canon and J. P. Stark (Mech. Eng. Dept., Univ. of Texas, Austin, Texas)

J. Less-Common Metals 17 [4], 451-54 (1969)

21. Study of the introduction of $U$ into liquid $F e$ and its behavior at $1600{ }^{\circ} \mathrm{C}$ towards various non-metallic elements: $\mathrm{O}_{2}, \mathrm{~S}, \mathrm{C}$ and $\mathrm{N}_{2}$ C. Catellier and M. Olette (IRSID, St. Germain en Laye, Fr.) Mém. Sci. Rev. Mét. 66, 407 (1969)

22. Behavior of silicate inclusions in Fe during hot rolling

J.A. Charles and I. Uchiyama (Met. Dept., Univ. of Cambridge, U.K.)

J. Iron Steel Inst. (London) 207, 979-83 (1969) 
H. 23. Habit modification of $\mathrm{Y}_{3} \mathrm{Ga}_{6} \mathrm{O}_{1}$ a grown from melts of $\mathrm{PbO}-\mathrm{PbF}_{2}$ doped with $\mathrm{SiO}_{2}$

A. B. Chase and J. A. Osmer (Aerospace Corp., Los Angeles, Calif. 90045)

Acta Cryst. A25 [S3], S241 (1969)

24. Plasma-grown rutile single crystals and their distinctive properties

J. D. Chase and L. J. van Ruyven (Ctr. Res. Div., Amer. Cyanamid Co., Stamford, Conn. 06904)

J. Crystal Growth $\underline{5}$ [4], 294-98 (1969)

25. Lattice and grain-boundary diffusion of $\mathrm{Ag}$ in $\mathrm{Au}$

A. Chatterjee and D. J. Fabian (Phys. Dept., Univ. of Reading, Eng1.)

Acta Met. 17 [8], 1141-44 (1969)

26. Preparation and crystallographic study of two mixed oxides with the perovskite structure

C. Chauvel, J. C. Bernier and A. Michel (Fac. Sci., 91-Orsay, Fr.)

C. R. Acad. Sci. 268C, 2085 (1969)

27. Observations during the carburation of $\mathrm{Ti}$ wires

J. L. Chermant, A. Deschanvres, G. Manier and G. Verge (Fac. Sci. Caen, 14-Caen, Fr.)

C. R. Acad. Sci. 268C, 2291 (1969)

28. Effect of alloying elements on the behavior of nonferrous metal impurities in $\mathrm{Ni}$ and $\mathrm{Fe}$ during in-vacuo melting

B. G. Chernov and P. Ya. Ageev

Izv. Vyssh. Ucheb. Zaved., Chern. Met. 12 [4], 5-9 (Apr. 1969)

29. Kinetics of reduction of $\mathrm{Zn}$ from silicate melts with CO

V. M. Chmarev and T. F. Vlasova

Izv. Akad. Nauk SSSR, Metal. [3], 52-55 (May-June 1969)

30. Growth of single crystals of CdS

L. Clark and J. Woods (Appl. Phys. Dept., Univ. of Durham, Engl.)

J. Crystal Grow th $3-4$, 127-30 (1968)

31. Developments in melt-grown oxide crystals

B. Cockayne (Royal Radar Est., Malvern, Worcs., Engl.)

J. Crystal Growth 3-4, 60-70 (1968)

32. Growth of yttrium aluminate and yttrium aluminum garnet by a hollow cathode floating-zone method

W. Class (Mater. Res. Co., Orangeburg, N. Y. 10962)

J. Crystal Growth 3-4, 241-45 (1968)

33. Effect of structure of $\mathrm{Zr}-\mathrm{Cu}$ alloys on their resistance to oxidation in $\mathrm{CO}_{2}$ at elevated temperatures

R. Darras and H. Loriers (C.E.N. Saclay, 91-Gif sur Yvette, Fr.)

C. R. Acad. Sci. 268C, 2244 (1969) 
H. 34. Oxidation of $\mathrm{Zr}-\mathrm{Cu}$ alloys in $\mathrm{CO}_{2}$ at elevated temperatures

R. Darras, H. Loriers and P. Bacqe (C.E.N. Saclay, 91-Gif sur Yvette, Fr.)

C. R. Acad. Sci. 268C, 1317 (1969)

35. Melt growth of refractory oxide single crystals

H. M. Dess

Chem. Eng. Progr., Symp. Ser. 65 [95], 100-11 (1969)

36. Precipitation of boron in silicon

P. S. Dobson (Dept. Phys. Met. and Sci. Mater., Univ. of Birmingham: Engl.) and J. D. Filby (Royal Radar Est., Malvern, Worcs., Engl.)

J. Crystal Growth 3-4, 209-13 (1968)

37. The growth of austenite grain of plain carbon steels at $700-1200{ }^{\circ} \mathrm{C}$ A. Domsa, E. Bicsak and M. Filipescu

Arch. Eisenhüttenw. 40, 489-92 (1969)

38. Reactive vacuum evaporation of TiO with simultaneous oxidation to $\mathrm{TiO}_{2}$

B. Dudenhausen and G. Möllenstedt (Univ. Tubingen, Inst. Angew. Phys., Tubingen 7400, Germ.)

Z. Angew. Phys. 27 [3], 191-97 (1969)

39. Synthesis and properties of Li septagermanate

C. O. Dugger (A. F. Cambridge Res. Lab., Bedford, Mass. 01730)

J. Crystal Growth $\underline{3-4}, 275$ (1968)

40. Oxidation of metals at high temperatures in the non-stationary

(transition) region. II. Experimental data on oxidation of Ti

V. I. Dyachkov and V. I. Tikhomirov

Fiz. Metal. Metallov. 27 [4], 655-62 (1969)

41. Gravimetric studies on the mechanism of desulfurization of Fe melts containing Si under oxidizing conditions

T. El Gammal and H. Schenck (Inst. Eisenhüttenw., Rhein.-Westfäl. Tech. Hochschule, Aachen, Germ.)

Arch. Eisenhuittenw. 40, 197-99 (1969)

42. Crystal growth of ternary metal oxides by chemical transport

F. Emmenegger (Lab. RCA, Zürich, Switz.)

J. Crystal Growth 3-4, 135-40 (1968)

43. Heat of solution and diffusivity of $\mathrm{N}$ in Mo

J. H. Evans and B. L. Eyre (AERE, Harwell, Berks., Eng1.)

Acta Met. 17 [8], 1109-15 (1969)

44. Preliminary self-diffusion measurements with pyrocarbons

R. B. Evans, III, L. D. Love and E. H. Kobisk (Oak Ridge Nat. Lab., Oak Ridge, Tenn. 37830)

J.Appl. Phys. 40 [7], 3058-59 (1969) 
H. 45. Some regularities of interdiffusion in Fe-Co powder mixtures

I. M. Fedorchenko, I. I. Ivanova and O. I. Fushchich (Acad. Sci.,

Mat. Tech. Inst., Kiev, UkSSR)

Dopovidi Akad. Nauk Ukr. RSR, Ser. A [4], 356-59 (1969)

46. Interdiffusion in the Ti-V, Ti-Nb, Ti-Ta and Ti-Mo systems

S. G. Fedotov, M. G. Chudinov and K. M. Konstantinov

Fiz. Metal. Metallov. 27 [5], 873-76 (1969)

47. Rate of combustion of size graded fractions of char from a low rank coal between 1200 and $2000 \mathrm{~K}$

M. A. Field

Combust. Flame 13 [3], 237-52 (1969)

48. Effect of $\mathrm{Ni}$ on high temperature oxidation of copper-bearing steels

G. L. Fisher (INCO Res. Lab., Sterling Forest, Suffern, N. Y.)

J. Iron Steel Inst. (London) 207, 1010-16 (1969)

49. Growth of CdS single crystals of controlled composition from the vapour phase

P. D. Fochs, W. George and P. D. Augustus (Ctr. Res. Lab., Assoc. Electr. Ind., Rugby, Warwicks., Eng1.)

J. Crystal Growth 3-4, 122-25 (1968)

50. Vapor phase growth of $\mathrm{SnO}_{2}$ single crystals

C. G. Fonstad, A. Linz and R. H. Rediker (Electr. Eng. Dept.,

Mass. Inst. Tech., Cambridge, Mass.)

J. Electrochem. Soc. 116 [9], 1269-71 (1969)

51. Diffusion in iron

J. Fridberg, L. E. Torndahl and M. Hillert (Royal Inst. Tech., Stockholm, Sweden)

Jernkontorets Annaler 153 [6], 263 (1969)

52. Investigations on the distribution of $S$ between C-saturated molten

$\mathrm{Fe}$ and basic slags during the scorification of added elements

with affinity to $\mathrm{O}_{2}$, with special reference to $\mathrm{Si}$

M. G. Frohberg, A. Nilas and B. Schuh (Inst. Allgem. Met.,

Tech. Univ. Berlin)

Arch. Eisenhüttenw. 40, 191-95 (1969)

53. Interaction of a high alumina refractory with $\mathrm{Cr}$ vapors in vacuo M. I. Gasik, S. I. Khitrik, Yu. P. Pashkov, L. Ya. Grinberg and Yu. M. Chupakh in

Ogneupory $\underline{34}$ [6], 38-40 (June 1969)

54. Thermal stability of refractory materials in a gas flow G. A. Gogotsi, L. V. Kravchuk, R. I. Kuriat and G. N. Tretyachenko Teplofiz. Vys. Temp. $\underline{7}$ [3], 515-19 (1969) 
H. 55. Self-diffusion of carbon

E. S. Golovina, V.S Chaplygina and L. L. Kotova (Krzhizhanovskii Power Eng. Inst., Moscow)

Dok1. Akad. Nauk SSSR 187 [3], 558-61 (1969)

56. Molten film thickness during Verneuil synthesis of ruby and its effect on crystal perfection

J. G. Grabmaier (Forschungslab. München, Siemens AG, 8 Munich, Germ.)

J. Crysta1 Growth $\underline{5}$ [2], 105-10 (1969)

57. Mass dependence of self-diffusion in iron

D. Graham (NASA Lewis Res. Ctr., Cleveland, Ohio 44135)

J.Appl. Phys. 40 [6], 2386-90 (1969)

58. Reaction of titanium nitrides with $\mathrm{O}_{2}$ and $\mathrm{CO}_{2}$

Yu. G. Gurevich, Yu. K. Semenov and V. I. Eliseev

Izv. Vyssh. Ucheb. Zaved., Chern. Met. 12 [4], 10-12 (Apr. 1969)

59. Growth and characterization of single crystal $\mathrm{ZrB}_{2}$

J. S. Haggerty, J. L. O'Brien and J. F. Wenckus (A. D. Little, Inc., Cambridge, Mass. 02140)

J. Crysta1 Growth 3-4, 291-94 (1968)

60. Melting of vanadium carbide in the plasma stream furnace

K. Hanusch and H. Winterhager (Inst. Metallhütenw. u. Elektromet., Rhein.-Westfäl. Tech. Hochschule Aachen, Germ.)

Chem.-Ing.-Tech. 41, 687-88 (1969)

61. Lamellar glass-crystal structures in the system $\mathrm{ZnO}-\mathrm{B}_{2} \mathrm{O}_{3}$

D. E. Harrison (Westinghouse Res. Lab., Pittsburgh, Pa. 15235)

J. Crystal Growth 3-4, 674-78 (1968)

62. Diffusion of gases through graphite

P. Hawtin, R. W. Dawson and J. Roberts

Trans. Inst. Chem. Eng. 47 [5], 109-13 (1969)

63. Diffusion of ${ }^{55} \mathrm{Fe}$ in wustite as a function of composition at $1100{ }^{\circ} \mathrm{C}$

P. Hembree and J. B. Wagner, Jr. (Mater. Sci. Dept., Northwestern

Univ., Evanston, I11.)

Trans. Met. Soc. AIME 245 [7], 1547-52 (1969)

64. Nucleation and growth of oxide particles in metal vapor flames

R. W. Hermsen and R. Dunlap

Combust. Flame 13 [3], 253-61 (1969)

65. Alloy formation between low and very high-melting metals by reduction of volatile metal halides and studies of the structure of Mo-Zn alloys made using this method

Th. Heumann, H.W. Schleicher and H. Venker (Inst. Metallforsch., Univ. Münster, Germ.)

Z. Metallk. 60, 438-41 (1969) 
H. 66. Fluxed-melt growth of NiO crystals and their electrical properties

G. J. Hill (Electr. Res. Assoc., Leatherhead, Surrey) and

B. M. Wanklyn (Clarendon Lab., Phys. Dept., Univ. of Oxford, Eng1.)

J. Crystal Growth 3-4, 475-79 (1968)

67. Crystal growth and lattice parameters of rare-earth doped yttrium phosphate, arsenate and vanadate prepared by the oscillating temperature flux technique

W. Hintzmann and G. Müller-Vogt (Phys. Inst., Univ. of Karlsruhe, Germ.)

J. Crystal Growth 5 [4], 274-78 (1969)

68. Preparation of single crystals of Pt group transition metals and alloys

S. Hornfeldt, J. B. Ketterson and L. R. Windmiller (Argonne Nat. Lab., Argonne, IIl. 60439)

J. Crystal Growth $\underline{5}$ [4], 289-93 (1969)

69. Synthesis and stability of Ti-andradite

H. G. Huckenholz (Geophys. Lab., Carnegie Inst. Washington, D. C. 20008)

Am. J. Sci. (Schairer Vol.) 267A, 209-32 (1969)

70. The physical chemistry of transport processes

J. H. E. Jeffes (Met. Dept., Imperial Coll., London, SW 7)

J. Crysta1 Growth 3-4, 13-32 (1968)

71. Back stress in high temperature deformation

J. J. Jonas (Met. Eng. Dept., McGill Univ., Montreal, Can.)

Acta Met. 17 [4], 397-405 (1969)

72. High temperature vapour phase growth of Eu sulphide, selenide and telluride

E. Kaldis (Lab. für Festkörperphysik, E.T.H., Zürich, Switzerland)

J. Crystal Growth 3-4, 146-49 (1968)

73. Preparation of single crystals of $\mathrm{CdGeAs}_{2}$ by a zone melting method J. Kaspar (Inst. Solid State Phys., Czech. Acad. Sci., Prague)

J. Crystal Growth 3-4, 277 (1968)

74. The thermodynamic properties of gaseous $\mathrm{Nb}$ chlorides

F. J. Keneshea and D. Cubicciotti (Stanford Res. Inst., Menlo Park, Calif. 94025)

J. Phys. Chem. 73 [9], 3054-62 (1969)

75. Incorporation of increased concentrations of rare earth activator ions in optical quality single crystals of yttrium aluminum garnet

M. Kestigian and W. W. Holloway, Jr. (Sperry Rand Res. Ctr., Sudbury, Mass. 01776)

J. Crystal Growth 3-4, 455-57 (1968) 
H. 76. Interaction of $\mathrm{Mg}$ aluminate and $\mathrm{Mg}$ chromate spinels with calcareous Fe melts

Ya. V. Klyucharov and N. V. Meshalkina

Ogneupory $\underline{34}$ [7], 44-47 (July 1969)

77. Evidence of dendritic and cellular growth in $\alpha-\mathrm{Al}_{2} \mathrm{O}_{3}$

H. E. LaBelle, Jr. and A. I. Mlavsky (Tyco Labs., Waltham, Mass. 02154)

Acta Cryst. A25 [S3], S241 (1969)

78. Effect of the characteristics of a polycrystalline aggregate on solid-state growth of a single crystal of a hexagonal ferrite

C. Lacour and M. Paulus (CNRS Lab. Magnét. et Phys. Solide, 92Bellevue, Hauts de Seine, Fr.)

J. Crystal Growth 3-4, 814-17 (1968)

79. Preparation of the precious metals, their alloys and pseudo-alloys R. Lacroix (Comptoir Lyon Alemand, Paris)

Ind. Céram. [167], 257 (1969)

80. Growth of single crystals of $\mathrm{Bi}_{4}\left(\mathrm{GeO}_{4}\right)_{3}$

J. Liebertz (Philips Zentrallab. GmbH, Weisshausstr. 51, Aachen, Germ.)

J. Crystal Growth 5 [2], 150 (1969)

81. Epitaxial growth of narrow linewidth yttrium iron garnet films

R. C. Linares (Perkin-Elmer Co., Norwalk, Conn. 06852)

J. Crystal Growth 3-4, 443-46 (1968)

82. Oxide formation and separation during deoxidation of molten Fe with Mn-Si-Al alloys

P. H. Lindon and J. C. Billington (Met. Dept., Univ. of Aston in Birmingham, Engl.)

Trans. Met. Soc. AIME 245 [8], 1775-84 (1969)

83. Growth and characterization of variable stoichiometry spinels H. G. Lipson, A. Kahan and J. A. Adamski (A. F. Cambridge Res. Lab., Bedford, Mass. 01730) and E. Farrell, M. J. Redman and J. Kawamura (Ctr. Mater. Sci. and Eng. and Electr. Eng. Dept., M.I.T., Cambridge, Mass. 02139)

J. Crystal Growth 3-4, 250-54 (1968)

84. Factors affecting the reoxydation of molten steel during continuous casting

J. Little, M. van Oosten and A. McLean (Met. and Mater. Sci. Dept., McMaster Univ., Hamilton, Ont., Can.)

Can. Met. Quart. 7 [4], 235-46 (1968)

85. Electrochemical measurements of oxygen during the reduction of silicate slags by means of C-saturated $\mathrm{Fe}$ in a C crucible W. Löscher (Hoesch AG Hïttenwerke, Dortmund, Germ.)

Arch. Eisenhüttenw. 40, 479-87 (1969) 
H. 86. Growth from metal solutions

N. P. Luzhnaya (Inst. Gen. and Inorg. Chem., Acad. Sci. USSR, Moscow)

J. Crystal Growth 3-4, 97-107 (1968)

87. Diffusion of $\mathrm{C}$ in alloys of $\mathrm{Nb}$ with $\mathrm{Ti}, \mathrm{Zr}, \mathrm{W}$ and Mo

V. D. Lyubimov, P. V. Geld, G. D. Bogomolov, V. A. Tskhai and G. P. Shveikin

Izv. Akad. Nauk SSSR, Metal. [3], 201-06 (May-June 1969)

88. Effect of impurities on mullite formation from kaolinite-type minerals

K. J. D. Mackenzie (Chem. Dept., Victoria Univ. of Wellington, New. Zealand)

Trans. Brit. Ceram. Soc. 68, 97-109 (1969)

89. Disproportionation of $\mathrm{GeO}$

R. L. Magunov, O. V. Zakolodiazhnaya, N. M. Bondar and M. N. Puring (Acad. Sci., Inst. Gen. \& Inorg. Chem., Kiev, UkSSR)

Izv. Akad. Nauk SSSR, Neorg. Mater. 5 [7], 1300-01 (1969)

90. Improvement in yield of yttrium iron garnet

H. Makram (CNRS Lab. Magnét. et Phys. Solide, 92-Bellevue, Fr.)

J. Crystal Growth 3-4, 447-51 (1968)

91. Effect of pressure on the homogeneous distribution of $\mathrm{Ga}$ in single crystal yttrium iron garnet

H. Makram, L. Touron and J. Loriers (CNRS Lab. Magnét. et Phys . Solide, 92-Bellevue, Fr.)

J. Crystal Growth 3-4, 452-54 (1968)

92. Growth and characterization of a transition metal silicide

R. C. Marshall (A. F. Cambridge Res. Lab., Bedford, Mass. 01730)

J. Crystal Growth 3-4, 295-99 (1968)

93. Reduction of some oxides by WC. Double carbides of W with Fe, Co or $\mathrm{Ni}$

Y. Mary (Lab. Chim. Minér., Sorbonne, Paris)

Rev. Chim. Minér. 6, 585 (1969)

94. As isoconcentration diffusion studies in Si

B. J. Masters and J. M. Fairfield (IBM Components Div., E. Fishkill Facility, Hopewel1 Junction, N. Y. 12533)

J. App1. Phys. 40 [6], 2390-94 (1969)

95. High-pressure synthesis of perovskite-type $\mathrm{Pb}\left(\mathrm{Zn} \frac{1}{3} \mathrm{Nb} \frac{2}{3}\right) \mathrm{O}_{3}$

Y. Matsuo, H. Sasaki, S. Hayakawa, F. Kanamaru and M̆. Koizumi (Wireless Res. Lab., Matsushita Electric Ind. Co., and Inst. Sci. \& Ind. Res., Osaka Univ., Osaka, Japan)

J.Am. Ceram. Soc. 52 [9], 516-17 (1969) 
H. 96. The growing of CdTe single crystals

0. A. Matveev, S. V. Prokofiev and I. V. Rud (Acad. Sci., Ioffe Phys. Tech. Inst., Leningrad, USSR)

Izv. Akad. Nauk SSSR, Neorg. Mater. 5 [7], 1175-80 (1969)

97. Thermodynamic analysis of the formation of zircon from oxides

G. M. Matwejew, A. S. Agarkow and F. Kerbe (Inst. Tech. Keramik, Hermsdorf, Thüringen, Germ.)

Silikattech. 20, 86-88 (1969)

98. On uranium self-diffusion in $\mathrm{UO}_{Z}$ and $\mathrm{UO}_{2}+x$

H. Matzke (Chem. Dept., CCR Euratom, Ispra (Varese), Italy)

J. Nucl. Mater. 30 [1-2], 26-35 (1969)

99. Czochralski-growth of calcium fluorphosphate

R. Mazelsky, R. H. Hopkins and W. E. Kramer (Westinghouse Res. Lab., Pittsburgh, Pa. 15235)

J. Crystal Growth 3-4, 360-64 (1968)

100. Preparation of cadmium telluride single crystals by Iiquid encapsulation

G. S. Meiling and R. Leombruno (Corning Glass Works, Corning, N. Y. 14830)

J. Crystal Growth $3-4,300$ (1968)

101. The spherulitic growth of graphite crystals

I. Minkoff (Technion, Haifa, Israel)

J. Crystal Growth 3-4, 328 (1968)

102. A transport reaction for the growth of Pr phosphide

K. E. Mironov (Inst. Inorg. Chem., Acad. Sci. USSR, Novosibirsk 90, USSR)

J. Crystal Growth 3-4, 150-52 (1968)

103. Liquid encapsulation crystal pulling at high pressures

J. B. Mullin, R. J. Heritage, C. H. Holliday and B. W. Straughan (Royal Radar Estab., Malvern, Worcs., Engl.)

J. Crystal Growth 3-4, 281-85 (1968)

104. Anomalous diffusion in $\beta-\mathrm{Zr}, \beta-\mathrm{Ti}$ and $\mathrm{V}$

M. C. Naik and R. P. Agarwala (Bhabha Atomic Res. Ctr., Trombay, Bombay, India)

J. Phys, Chem. Solids 30, 2330-34 (1969)

105. Synthesis of barium ferrates in oxygen

T. Negas and R. S. Roth (Nat. Bur. Stds., Washington, D. C. 20234)

J. Res. Nat. Bur. Std. 73A [4], 425-30 (1969)

106. Synthesis and fabrication of (U, Pu)C nuclear fuel pellets from $\mathrm{U}-\mathrm{Pu}$ alloy

P. A. Nelson, D. E. Grosvenor, S. Vogler, N. P. Quattropani and P. W. Krause (Argonne Nat. Lab., Argonne, Ill.)

Am. Ceram. Soc. 48 [9], 863-66 (1969) 
H. 107. Growth of ZnO single crystals by the vapor phase reaction method K. F. Nielsen (Phys. Dept. Sect. III, Tech. Univ. of Denmark, Lyngby, Denmark)

J. Crysta1 Growth $3-4,141-45$ (1968)

108. Crystallization of $\mathrm{LaB}_{6}$

T. Niemyski (Inst. Electron Tech., Polish Acad. Sci., Warsaw) and E. Kierzek-Pecold (Inst. Phys., Polish Acad. Sci., Warsaw)

J. Crystal Growth 3-4, 162-65 (1968)

109. The reduction of molten blast furnace slags by elementary $\mathrm{C}$ and $\mathrm{Fe}$ melts saturated with $\mathrm{C}$

W. Oelsen and H. G. Schubert (Max Planck Inst. Eisenforsch., Düsseldorf) and 0 . Oelsen (Werk Ruhrort, A. Thyssen-Hïte AG, Duisburg-Meiderich, Germ.)

Arch. Eisenhüttenw. 40, 173-90 and 277-83 (1969)

110. Comparison of the behavior of alumina and silica in the reaction of slags rich in lime with Fe melts in a graphite crucible

W. Oelsen, H. G. Schubert and K. Klein (Max Planck Inst.,

Eisenforsch., Dïsseldorf, Germ.)

Arch. Eisenhüttenw. 40, 201-13 (1969)

111. Chlorination of $\mathrm{ZnO}$ : equilibrium measurements

A. K. Orlov and J. H. E. Jeffes (Met. Dept., Imperial College, Lond on, SW 7)

Trans. Inst. Mining Met. 78C, 87-90 (1969)

112. Iodine-doped hollow CdS crystals

C. Paorici (Ist. Fis., Univ. di Parma, Italy)

J. Crysta1 Growth $\underline{5}[4], 315-16$ (1969)

113. Solubility and diffusivity of $\mathrm{O}$ in solid $\mathrm{Cu}$ from electrochemical measurements

R. L. Pastorek and R. A. Rapp (Met. Eng. Dept., Ohio State Univ., Columbus, Ohio)

Trans. Met. Soc. AIME 245 [8], 1711-20 (1969)

114. Growth of Mn ferrite crystals

M. Paulus and A. Hamelin (CNRS Lab. Magnét. et Phys. Solide, 92-Bellevue, Hauts de Seine, Fr.)

J. Crystal Growth 3-4, 500-03 (1968)

115. Diffusion of $\mathrm{Be}$ in $\mathrm{Zr}$ and $\mathrm{Ti}$

L. V. Pavlinov, G. V. Grigorev and G. O. Gromyko

Izv. Akad. Nauk SSSR, Metal. [3], 207-09 May-June 1969)

116. Tracer diffusion in tungsten

R. E. Pawel and T. S. Lundy (Oak Ridge Nat. Lab., Oak Ridge, Tenn. 37830)

Acta Met. 17 [8], 979-88 (1969) 
H. 117. Diffusion of ${ }^{51} \mathrm{Cr}$ into polycrystalline $\mathrm{Nb}$

J. Pelleg (Structures and Mater., Nat. Aeronaut. Establ., Nat. Res. Council, Ottawa, Can.)

J. Less-Common Metals 17 [3], 319-24 (1969)

118. On the self-diffusion of $\mathrm{Nb}$

J. Pelleg and G. M. Lindberg (Nat. Aeronaut. Estab., Nat. Res. Council, Ottawa, Can.)

Trans. Met. Soc. AIME 245 [7], 1654-55 (1969)

119. Reduction of iron ore compacts

M. D. Pepper and B. L. Daniell (Met. Dept., Univ. of Surrey, Guildford, U. K.)

J. Iron Stee1 Inst. (London) 207, 972-78 (1969)

120. The preparation of $\mathrm{Eu}_{2} \mathrm{SiO}_{4}$

H. Pink (Forschunglab., Siemens A.G., München, Germ.)

J. Less-Common Metals 17 [2], 247 (1969)

121. Enstatite: disorder produced by a megabar shock event

S. S. Pollack (Mellon Inst., Carnegie-Mellon Univ., Pittsburgh, Pa. 15213) and P. S. DeCarli (Stanford Res. Inst., Menlo Park, Calif. 94025)

Science 165 [3893], 591-92 (1969)

122. Behaviour of solid solutions of rare earth oxides in binary systems during crystallization by the Verneuil method

A. A. Popova (Inst. Cryst., Acad. Sci. USSR, Moscow)

J. Crystal Growth 3-4, 255-59 (1968)

123. Vapor phase growth of refractory fluoride single crystals

K. Recker and R. Leckebusch (Mineral. Inst., Univ. Bonn, Germ.)

J. Crystal Growth 5 [2], 125-31 (1969)

124. Diffusion of ${ }^{233} \mathrm{U}$ in $\mathrm{UO}_{2}$

D. K. Reimann and T. S. Lundy (Oak Ridge Nat. Lab., Oak Ridge, Tenn. 37830)

J.Am. Ceram. Soc. 52 [9], 511-12 (1969)

125. Solubility of cerium oxides in alkali chloride melts

G. Reinhard and D. Naumann (Zentralinst. Kernforschung, Deut. Akad. Wissen. Berlin, Dresden, DDR)

Z. Phys. Chem. (Leipzig) 238, 309-20 (1968)

126. Silicon dioxide dissolution in molten glass

E. F. Riebling (Corning Glass Works, R/D Labs., Corning, N. Y.) Am. Ceram. Soc. Bull. 48 [8], 766-69 (1969)

127. A simple furnace for the growth of single crystals from fluxed melts under pressure

J. M. Robertson, S. H. Smith and D. Elwell (Phys. Dept., Portsmouth Coll. Tech., Portsmouth, Engl.)

J. Crystal Growth $\underline{5}$ [3], 189-92 (1969) 
H. 128. Surface diffusion of oxides

W. M. Robertson (Sci. Ctr., North Am. Rockwell Co., Thousand Oaks, Calif. 91360)

J. Nucl. Mater. $\underline{30}$ [1-2], 36-49 (1969)

129. Method of synthesis and growth from solution of homogeneous single crystals of semiconductors

H. Rodot, A. Hruby and M. Schneider (CNRS Lab. Magnét. et Phys. Solides, 92-Bellevue, Meudon, Fr.)

J. Crysta1 Growth 3-4, 305-08 (1968)

130. High temperature solution ( $f l u x$ ) and high pressure solution (hydrothermal) crystal growth

R. Roy and W. B. White (Mater. Res. Lab., Pennsylvania State Univ., Univ. Park, Pa. 16802)

J. Crystal Growth 3-4, 33-42 (1968)

131. Contact interaction of silicon and boron carbides and their compounds with liquid metals

G. V. Samsonov, A. D. Panasyuk and G. K. Kozin (Acad. Sci., Mater. Tech. Inst., Kiev, UkSSR)

Dopovidi Akad. Nauk Ukr. RSR, Ser. A [5], 468-71 (1969)

132. The reaction of $\mathrm{CO}$ with a Ta surface heated above $2000 \mathrm{~K}$

M. D. Scheer and J. Fine (Nat. Bur. Stand., Washington, D. C. 20234)

Surface Sci. 12 [1], 102-07 (1968)

133. Growth of mixed cation iron garnets in the $\mathrm{Yb}-\mathrm{Ga}$ and $\mathrm{Y}-\mathrm{Ca}$ silicate systems

M. Schieber, A. Grill and I. Shidlovsky (Phys. Dept., Hebrew Univ., Jerusalem, Israel)

J. Crystal Growth 3-4, 467-70 (1968)

134. The dissolution of $\mathrm{CaO}$ in Ca-Fe silicate slags at $1375{ }^{\circ} \mathrm{C}$

W. J. Schlitt, III (Pennsylvania State Univ., 1968)

Dissertation Abstr. 29B [12], 4680 (1968-69)

135. Evidence for $2 \mathrm{H}-\mathrm{SiC}$ whisker growth by a screw dislocation process

$\mathrm{N}$. Setaka and K. Ejiri (Nat. Inst. Res. Inorg. Mater. and Fac. Sci., Univ. of Tokyo)

J. Am. Ceram. Soc. $\underline{52}$ [7], 400 (1969)

136. The preparation and growth of single crystals of some ternary sulphides

W. A. Shand (Signals R/D Establ., Christchurch, Hants, Engl.)

J. Crystal Growth 5 [3], 203-05 (1969)

137. Single crystal growth and some properties of $\mathrm{LiYF}_{4}$

W. A. Shand (Nat. Phil. Dept., Univ. of Aberdeen, Scotland)

J. Crystal Growth $\underline{5}$ [2], 143-46 (1969) 
H. 138. Reaction kinetics of $\mathrm{Cr}_{2} \mathrm{O}_{3}$ with a lime-alumina melt

V. D. Shantarin, Yu. A. Deryabin, S. I. Suchilnikov and V. A. Pavlov

Izv. Akad. Nauk SSSR, Metal. [3], 47-51 (May-June 1969)

139. Oxidation of $\mathrm{V}$ in iron carbide melts

Yu. S. Shchekalev, S. I. Popel and A. I. Pastukhov

Izv. Vyssh. Ucheb. Zaved., Chern. Met. 12 [4], 13-17 (April 1969)

140. Growth of nickel ferrite crystals from barium borate by a pulling method

S. H. Smith and D. Elwell (Phys. Dept., Portsmouth Coll. Tech., Portsmouth, Eng1.)

J. Crystal Growth $3-4,471-74$ (1968)

141. Mass spectrometric investigations of hydrogen-containing molecules of $\mathrm{B}$ and $\mathrm{C}$

S. J. Steck (Northwestern Univ., 1968)

Dissertation Abstr. 29B [11], 4084 (1968-69)

142. Coesite and stishovite

D. Stöffler and J. Arndt (Mineral.-Petrog. Inst., Univ. Tübingen, Germ.)

Naturwiss. 56, 100-09 (1969)

143. Growth of single crystals of graphite from a C-Fe melt

Y. Sumiyoshi and N. Ito (App1. Chem. Dept., Fac. Eng., Nagoya Univ., Chikusaku, Nagoya, Japan)

J. Crystal Growth $3-4,327$ (1968)

144. P and As doping of epitaxial Si films in the 1000 to $1200{ }^{\circ} \mathrm{C}$ temperature range

T. B. Swanson and R. N. Tucker (Fairchild Semiconductor R/D Lab., Palo Alto, Calif.)

J. Electrochem. Soc. 116 [9], 1271-74 (1969)

145. Preparation of semiconducting SiC single crystals

I. Swiderski, W. Proskurowski and T. Niemyski (Polish Acad. Sci., Inst. Electron. Tech., Zielna 37, Warsaw)

J. Crystal Growth $\underline{5}[1]$, 59-64 (1969)

146. Isomorphic impurity distribution in garnets as a function of the solubility of the tri-valent oxides in molten salts and the method of crystal growth

V. A. Timofeeva (Inst. Cryst., Acad. Sci. USSR, Moscow)

J. Crystal Growth 3-4, 496-99 (1968)

147. Growth of yttrium iron garnet single crystals

W. Tolksdorf (Philips Zentralab. GmbH, 2 Hamburg 54, Germ.)

J. Crystal Growth 3-4, 463-66 (1968) 
H. 148. Growing of $12 \mathrm{CaO} .7 \mathrm{~A} 1_{2} \mathrm{O}_{3}$ single crystals

N. A. Toropov, I. P. Udalov and Z. S. Medvedeva (Grebenshchikov

Silicate Chem. Inst., Leningrad, USSR)

Izv. Akad. Nauk SSSR, Neorg. Mater. 5 [7], 1304-05 (1969)

149. Kinetics of the vapor growth of II-VI compound crystals. II. Zinc selenide

M. Toyama and T. Sekiwa (Tokyo Shibaura Elect. Co., Kawasaki, Japan)

Japan. J. Appl. Phys. $\underline{8}$ [7], 855-59 (1969)

150. Dissolution of silica glass in $\mathrm{Na}_{2} \mathrm{O}-\mathrm{CaO}-\mathrm{SiO}_{2}$ melts

M. Truhlářová and O. Vepřek (Silicate Res. Lab., Czech. Acad. Sci., Prague)

Glastech. Ber. 42, 9-11 (1969)

151. Synthesis of single crystals of some uranium oxides

A. N. Tsvigunov, E. Yu. Kuzmichiova and L. M. Kovba (State Univ., Inorg. Chem. Dept., Moscow)

Vest. Mosk. Univ., Khim. [4], 117 (July-Aug. 1969)

152. Growth of magnetite crystals from a borax flux

M. Vichr (CNRS Lab. Terres Rares, 92-Bellevue) and H. Makram (CNRS Lab. Magnét. et Phys. Solide, 92-Bellevue, Fr.)

J. Crystal Growth $\underline{5}[1], 77-78$ (1969)

153. Solid solubility and diffusion coefficients of $B$ in Si

G. L. Vick and K. M. Whittle (Instr. Controls Div., Conrac Co., Duarte, Calif.)

J. Electrochem. Soc. 116 [8], 1142-44 (1969)

154. Ternary diffusion in Fe-Co-Ni alloys

A. Vignes and J. P. Sabatier (E.N.S. Mét. et Ind. Mines; Univ. of Nancy, Fr.)

Trans. Met. Soc. AIME 245 [8], 1795-1802 (1969)

155. A technique for vapor phase growth of ZnSe

P. Voh1 (Itek Co. Res. Labs., Lexington, Mass.)

Mater. Res. Bull. 4 [9], 689-98 (1969)

156. Oxidation equilibria and oxygen transport in calcium silicate slags

P. Vygen and H. J. Engell (Max Planck Inst. Eisenforsch.,

Düsseldorf, Germ.)

Arch. Eisenhüttenw. 40, 359-65 (1969)

157. Isotope effect in self-diffusion in Fe

C. M. Walter (Northwestern Univ., 1968)

Dissertation Abstr. 29B [11], 4202 (1968-69) 
H. 158. Growth and characterization of large stoichiometric magnesium aluminate spinel single crystals

C. C. Wang and S. H. McFarlane, III (RCA Lab., Princeton, N. J. 08540)

J. Crysta1 Growth 3-4, 485-89 (1968)

159. The growth of ceria crystals from $\mathrm{PbF}_{2}$ flux

B. M. Wanklyn (Clarend on Lab., Oxford Univ., Oxford, Engl.)

J. Crystal Growth $\underline{5}$ [3], 219-21 (1969)

160. $\mathrm{UO}_{2}$ cermets with idealized structure by particle coating and isostatic hot pressing

P. Weimar, F. Thümmler and H. Bumm (Inst. Mater. u. Festkörperforsch., Kernforschungszentr. Karlsruhe, Germ.)

J. Nucl. Mater. 31 [2], 215-25 (1969)

161. Decarburization of $\mathrm{Fe}-\mathrm{C}$ alloys by $\mathrm{Ar}-\mathrm{O}_{2}$ mixtures

S. G. Whiteway, R. J.W. Peters, W. D. Jamieson and C. R. Masson

(Nat. Res. Council, Atlantic Regional Lab., Halifax, N. S., Can.) Can. Met. Quart. 7 [4], 211-15 (1968)

162. Carbon: observations on the new allotropic form

A. G. Whittaker and P. L. Kintner (Mater. Sci. Lab., Aerospace Corp., El Segundo, Calif.)

Science 165 [3893], 589-91 (1969)

163. Growth of single crystals of rare-earth metals and binary alloys M. Whittaker (Metals Res. Ltd., Melbourn, Royston, Herts., Eng1.)

J. Crystal Growth 3-4, 317-20 (1968)

164. Growth of diamond seed crystals by vapor deposition

H. A. Will (Case Western Reserve Univ., 1968)

Dissertation Abstr. 29B [12], 4815 (1968-69)

165. Mullite formation from the sillimanite group minerals

H. H. Wilson (Clems on Univ., Clems on, S. C.)

Am. Ceram. Soc. Bull. 48 [8], 796-97 (1969)

166. Production of titanium nitride in direct current plasma

H. Winterhager and K. Hanusch (Inst. Metallhüttenw. u. Elektromet., Rhe in.-Westfäl. Tech. Hochschule, Aachen, Germ.)

Ber. Deut. Keram. Ges. 46, 181-85 (1969)

167. Oxygen diffusion in $\mathrm{Gd}_{2} \mathrm{O}_{3}$

C. D. Wirkus, M. F. Berard and D. R. Wilder (Inst. Atom. Res. \& Ceram. Eng. Dept., Iowa State Univ., Ames, Iowa 50010)

J.Am. Ceram. Soc. 52 [8], 456 (1969) 
H. 168. Growth of stoichiometric magnesium aluminate spinel crystals by flux evaporation

J. D. C. Wood and E. A. D. White (Electr. Eng. Dept., Imperial Coll., Exhibition Road, London SW 7)

J. Crystal Growth 3-4, 480-84 (1968)

169. Oxidation of $\mathrm{Fe}-\mathrm{Ni}$ alloys

G. L. Wulf, T. J. Carter and G. R. Wallwork (School of Met., Univ. of New South Wales, Kensington, N.S.W., Australia)

Corrosion Sci. 9, 471-78 and 689-701 (1969)

170. Growth of transparent, striation-free $\mathrm{Ba}_{2} \mathrm{NaNb}_{5} \mathrm{O}_{5}$ single crystals by a low-thermal-gradient Czochralski technique

R. R. Zupp, J. W. Nielsen and P. V. Vittorio (Be1l Te1. Labs., Murray Hill, N. J. 07974)

J. Crystal Growth $\underline{5}$ [4], 269-73 (1969)

I. Books

1. The journal of chemical thermodynamics

Ed. by M. L. McGlashan (Chem. Dept., The Univ., Exeter, Eng1.), H. A. Skinner (Chem. Dept., The Univ., Manchester, Eng1.) and

E. F. Westrum, Jr. (Chem. Dept., Univ. of Michigan, Ann Arbor, Mich.)

Academic Press, start 1969 (6 issues), \$19.50 per year 
Part II. GASES

A. Spectroscopy of Interest To High Temperature Chemistry

1. Overlapping atomic multiplets.

Juda, B. R. (Johns Hopkins Univ., Baltimore, Md.).

J. Opt. Soc. Amer. 1968, 58(9), 13II-I2.

2. Theoretical study of the BeH molecule.

Chan, Arthur C. H.; Davidson, Ernest R. (Univ• of Washington, Seattle, Wash.).

J. Chem. Phys. 1968, 49(2), 727-39.

3. Experimental transition probabilities for triplet-singlet transitions in helium-like heavy ions.

Sellin, I. A.; Donnally, Bailey I.; Fan, C. Y. (Oak Ridge Nat. Lab., Oak Ridge, Tenn.).

Phys. Rev. Lett. 1968, 21(II), 717-19.

4. New method for plotting potential curves of diatomic molecules using spectroscopic data. I. Potential curves of diatomic molecules in a generalized WKB [Wentzel-Kramers-Brillouin] zero approximation.

Zhirnov, N. I.; Vasilevskii, A. S. (USSR).

Opt. Spektrosk. 1968, 25(I), 28-35(Russ). CA Vol. 69, 80376q (1968).

5. Chemical applications of metastable excited argon atoms. I. The heat of formation of the cyanide radical.

Setser, D. W. ; Stedman, D. H. (Kansas State Univ., Manhattan, Kans.).

J. Chem. Phys. 1968, 49(1), 467-9.

6. Two-electron transitions in calcium and barium atoms. Kancerevicius, A. (Inst. Fiz. Mat., ViInius, USSR).

Liet. Fiz. Rinkinys, Liet. TSR Mokslu Akad., Liet. TSR Akust. Mokyklos 1967, 7(3), 611-18 (Russ). CA Vol. 69, 81852d (1968).

7. Absolute gf-values for chromium I and chromium II. Byard, P. I. (Ohio State Univ., Columbus, Ohio).

J. Quant. Spectrosc. Radiat. Transfer 1968, 8(9), 1543-9 (Eng).

8. Fourth and fifth spectra of vanadium (V IV and V V)

Iglesias, Laura (Inst. Opt., Madrid, Spain).

J. Res. Nat. Bur. Stand., Sect. A 1968 72(4), 295-308 (Eng).

9. Present state of analysis of the first spectrum of thorium (Th I). Zalubas, Romuald (Nat. Bur. of Stand., Washington, D. C.). J. Opt. Soc. Amer. 1968, 58(9), 1195-9 (Eng). 
A. 10. Perturbations in the Swan system of the $\mathrm{C}_{2}$ molecule. Phillips, John G. (Univ. of California, Berkeley, Calif.). J. Mol. Spectrosc. 1968, 28(2), 233-42 (Eng).

11. Short-range effects on the pressure shift for a nitrogen atom in a rare-gas atmosphere.

Ray, Supriya; Das, T. P. (Univ. of California, Riverside, Calif.). Phys. Rev. 1968, 174 (1), 32-44 (Eng).

12. "Abnormal" rotational energy distributions in the $C 3 I I_{u}-B 3 I I_{g}$ bands of $14 \mathrm{~N}_{2}$.

Bleekrode, R. (Phillips Res. Lab., N. V. Philips' Gloeilampenfabrieken, Eindhoven, Neth.).

J. Chem. Phys. 1968, 49(2), 951-3 (Eng).

13. Effect of thermal agitation on the measurement of excited atom lifetime.

Dumont, A. M. (Inst. Astrophys., C. N. R. S., Paris, Fr.).

J. Quant. Spectrosc. Radiat. Transfer 1968, 8(9), 1551-4 (Fr).

14. Transition probabilities in the spectra of neon I, argon I, and krypton I.

Murphy, Peter W. (Univ. of Maryland, College Park, Ma.). J. Opt. Soc. Amer. 1968, 58(9), 1200-8 (Eng).

15. Vibration rotation bands of heated hydrogen halides.

Webb, David U.; Rao, K. Narahari (Ohio State Univ., Columbus, Ohio). J. Mol. Spectrosc. 1968, 28(2), 121-4 (Eng).

16. Absorption coefficients of ozone in the ultraviolet and visible Regions.

Griggs, M. (Div. of Convair, Gen. Dyn., San Diego, Calif.). J. Chem. Phys. 1968, 49(2), 857-9 (Eng).

17. Ultraviolet absorption spectra of germanium monoiodide and silicon monoiodide.

Oldershaw, G. A.; Robinson, K. (Univ. Hull, Hull, Engl.).

Trans. Faraday Soc. 1968, 64 (9), 2256-9 (Eng).

18. Gas-phase far-ultraviolet absorption spectrum of hydrogen bromide and hydrogen iodide.

Huebert, B. J.; Martin, R. M. (Univ. of California, Santa Barbara, Calif.).

J. Phys. Chem. 1968, 72(8), 3046-8 (Eng).

19. Radiative lifetimes from ultraviolet lines of neon I, Neon II, and Neon III.

Hesser, James E. (Princeton Univ. Obs., Princeton N. J.) . Phys. Rev. 1968, 174(1), 68-74 (Eng). 
A. 20. Lifetime of the $2 \mathrm{~s} 2 \mathrm{p}^{2} 2 \mathrm{D}_{3} / 2,5 / 2$ states in the boron I spectrum determined from zero field level crossing.

Hese, A.; Weise, H. P. (Tech. Univ. Berlin, Berlin, Ger.). Z. Phys. 1968, 215(1), 95-102 (Ger).

21. Optical absorption measurements of ground-state CN in active nitrogen flames.

Iwai, Tsuruji; Pratt, D. W.; Broida, H. P. (Univ. of California Santa Barbara, Calif.).

J. Chem. Phys. 1968, 49(2), 919-26 (Eng).

22. Oscillator strengths of Eu I spectral lines.

Komarovskii, V. A.; Penkin, N. P.; Shabanova, I. N. (USSR) . Opt. Spektrosk, 1968, 25(1), 155-8 (Russ). CA Vol. 69, 81988 (1968).

23. Arc spectrum of zinc.

Johansson, Ingmar; Contreras, Ruben (Univ. Lund, Lund, Swed.). Ark. Fys. 1968, 37 (31), 513-20 (Eng).

24. Isotopic shift in the dysprosium spectrum.

Pacheva, I.; Abadzhieva, I. (Bulg.).

Izv. Fiz. Inst. ANEB, Bulg. Akad. Nauk. 1968, 17, 87-93 (BuIg).

25. Identification of the metastable autoionizing states in potassium with a new radio-frequency spectroscopic technique.

Sprott, G.; Novick, R. (Columbia Univ•, New York, N. Y.). Phys. Rev. Lett. 1968, 21(6), 336-9 (Eng).

26. High-resolution absorption, Zeeman, and magnetic rotation spectra of the fundamental and satellite bands of nitric oxide in the near infrared.

Keck, Donald B. (Michigan State Univ., East Lansing, Mich.). 1967, $260 \mathrm{pp}$. (Eng). Avail. Univ. Microfilms, Ann Arbor, Mich., Order No. 68-7914. From Diss. Abstr. B 1968, 28(12), 5153.

27. Collisional quenching of the B2II state of nitric oxide. Campbell, I. M.; Thrush, B. A. (Univ. Cambridge, Cambridge, Engl•). J. Quant. Spectrosc. Radiat. Transfer 1968, 8(9), 1571-5 (Eng).

28. New self-terminating laser transitions in calcium and strontium. Deech, J. S.; Sanders, J. H. (Oxford Univ., Oxford, Engl.). IEEE J. Quantum Electron. 1968, 4(7), 474 (Eng).

29. Reactions of excited atomic iodine $\left(5^{2} \mathrm{P}_{1 / 2}\right)$. III. Spectroscopic proof of the photochemical production of excited atoms in the banded region of the $\mathrm{B}^{3} \mathrm{II}_{\mathrm{Ou}}+\mathrm{X}^{1} \Sigma_{\mathrm{g}}{ }^{+}$system, and a correlation with the reaction rate.

Broadbent, T.W.; Callear, A. B.; Lee, H. K. (Phys. Chem. Lab., Cambridge, Engl.).

Trans. Faraday Soc. 1968, 64(9), 2320-4 (Eng). 
A. 30. Improvements in preparation and operation of elecrodeless discharge lamps as high intensity sources in atomic fluorescence flame spectrometry.

Zacha, K. E.; Bratzel, M. P., Jr.; Winefordner, J. D.; Mansfield J. M., Jr. (Univ. of Florida, Gainesville, Fla.).

Anal. Chem. 1968, 40(11), 1733-6 (Engl).

31. Structure of electronically excited molecules.

Seip, Hans M. (Univ. Oslo, Oslo, Norway).

Tidsskr. Kjemi, Bergv. Met. 1968, 28(5), 124-32 (Norweg).

32. $\mathrm{NaO}^{+}$production from sodium and $\mathrm{O}_{2}{ }^{+}$in merged beams.

Rol, P. K.; Entemann, E. A. (Space Sci, Lab., Gen. Dynam./Convair, San Diego, Calif.).

J. Chem. Phys. 1968, 49(3), 1430-1 (Eng).

33. Charge transfer and atom transfer in ion-molecule interactions studied by a time-of-flight mass spectrometer.

Homer, J. B.; Lehrle, R. S.; Robb, J. C.; Thomas, D. W. (Dep. Pure Chem., Nat. Res. Counc., Ottawa, Can.). Advan. Mass Spectrom. 1966, 3, 415-32 (Eng).

34. A theoretical study of the $I_{\Sigma^{+}}, 3_{\Sigma}^{+}, 3_{\pi}, l_{\pi}$ states of NaLi and the $2 \Sigma^{+}$state of $\mathrm{NaLi}^{+}$.

Bertoncini, Peter Joseph (Univ. of Wisconsin, Madison, Wis.). 1968, 109 pp. (Eng). Avail. Univ. Microfilms, Ann Arbor, Mich., Order No. 68-7087. From Diss. Abstr. B 1968, 29(1), 131.

35. Perturbation-theoretic approach to potential-energy curves of diatomic molecules.

Parr, Robert G.; White, Ronald J. (Univ. Oxford, Oxford, Engl.). J. Chem. Phys. 1968, 49(3), 1059-62 (Eng).

36. Effect of additives upon the reaction of cyanogen with active nitrogen: reactions of carbon atoms, CN radicals, and the chemilurinescent reaction of $\mathrm{C}_{2} \mathrm{~N}$ radicals with atomic oxygen. Safrany, David R.; Jaster, Walter (Whiteshell Nucl. Res. Estab., At. Energy Canada, Itd., Pinawa, Manitoba).

J. Phys. Chem. 1968, 72(9), 3318-22 (Eng).

37. Determination of energies of dissociation of some monohalides of the carbon subgroup.

Kuzyakov, Yu. Ya. (USSR).

Vestn. Mosk. Univ., Khim. 1968, 23(3), 2104 (Russ). CA Vol. 69 90539 (1968). 
A. 38. Re-evaluation of the dissociation energy of calcium fluoride. Hastie, J. W.; Margrave, J. I. (Rice Univ., Houston, Tex.). J. Chem. Eng. Data 1968, 13(3), 428-9 (Eng).

39. New type of perturbation caused by a magnetic hyperfine interaction, observed in the ground state of VO.

Richards, D.; Barrow, R. F. (Univ. Oxford, Oxford, Engl.). Nature 1968 219(5160), 1244-5 (Eng).

40. Vacuum ultraviolet resonance lines.

Getoff, N. (Univ. Vienna, Vienna, Austria).

Tech. Rep. Ser., Int. At. Energy Agency. 1967 (Pub. 1968), No. 84, $172-4$ (Eng).

41. First excited state of $\mathrm{NO}^{+}$.

Sjoergren, H.; Szabo, I. (Dep. Phys., Roy. Inst. Technol., Stockholm, Swed.).

Ark. Fys. 1968, 37(34), 551-5 (Eng).

42. Broadening of the 4226.73-A. line $\left(4 s^{2} I_{S_{O}}-4 p^{I} I_{P_{1}} 0\right)$ of calcium $I$ in laboratory spectra and in M-type stars.

Weniger, S. (Observ. Paris, Meudon, Fr.).

U. S. At. Energy Comm. 1966, CONF-660665, 25-34 (Fr). From Nuc1. Sci. Abstr. 1968, 22(12), 23972.

43. Attribution of the visible system of $\mathrm{SnCl}$ bands at the $\mathrm{A}^{2} \mathrm{X}^{+}-$ $\mathrm{X} 3 \mathrm{II}_{1} / 2$ transition.

Pannetier, Guy; Deschamps, Pascal (Iab. Cinet. Chim. Fac. Sci. Paris, Paris, Fr.).

J. Chim. Phys. Physicochim. Biol. 1968, 65(6), 1164-70 (Fr).

44. Continuum emission from xenon in the vapor phase induced by absorption of $1470-A$. radiation.

Sieck, I. Wayne (Radiat. Chem. Sect., Nat. Bur. of Stand., Washington, D. C.).

J. Phys. Chem. 1968, 72(9), 3129-33 (Eng).

45. Observation and vibrational analysis of a new system of germanium monochloride bands: $A^{2} \Sigma^{+}-X^{2} I I$.

Deschamps, Pascal; Robert, Anne Francoise; Pannetier, Guy (Lab. Cinet. Chim., Fac. Sci. Paris, Paris, Fr.).

J. Chim. Phys. Physicochim. Biol. 1968, 65(6), 1084-9 (Fr.).

46. Electronic states of the nitric oxide ion.

Collin, J. E.; Natalis, P. (Univ. Liege, Liege, Belg.).

Chem. Phys. Lett. 1968, 2(3), 194-6 (Eng). 
A. 47. Measurements in the spectrum of atomic oxygen, $O I$. Eriksson, Karl Borje S.; Isberg, H. Bengt S. (Univ. Lund, Iund, Swed.).

Ark. Fys. 1968, 37(17), 221-30 (Eng).

48. The production of monochromatic radiation with spectral lamps. Klier, R. (Osram G.m.b.H., Munich, Ger.). G-I-I (Glas-Instrum.-Tech.) Fachz. Lab. 1968, 21(1), 10-11 (Ger).

49. Measurement of the sodium D-line absolute oscillator strengths by the Roschdestvenskii hook method.

Forbrich, Carl A., Jr.; Marlow, Wayland C.; Bershader, Daniel (U. S. Air Force Acad., Colorado Springs, Colo.). Phys. Rev. 1968, 173(1), 150-4 (Eng).

50. Pressure-dependence of the yellow nitrogen afterglow intensity. Brennen, W.; Shane, E. C. (Univ. of Pennsylvania, Philadelphia, Pa.).

Chem. Phys. Lett. 1968, 2(3), 143-4 (Eng).

51. Lifetime of fluorescence from the lowest electronic state in sulfur dioxide vapor.

Caton, Robert Brent (Univ. of Rochester, Rochester, N. Y.). 1968, $112 \mathrm{pp.} \mathrm{(Eng).} \mathrm{Avail.} \mathrm{Univ.} \mathrm{Microfilms,} \mathrm{Ann} \mathrm{Arbor,}$ Mich., Order No. 68-9357. From Diss. Abstr. B 1968, 29(1), 314 .

52. Dicke narrowing and collisional broadening of the $\mathrm{S}_{0}(0)$ Raman line of hydrogen.

Cooper, V. G.; May, A. D.; Hara, E. H.; Knapp, H. F. P. (Univ. Toronto, Toronto, Ont.).

Can. J. Phys. 1968, 46(18), 2019-23 (Eng).

53. The $D$ and $D^{\prime}$ states of the PO molecule.

Verma, R. D.; Dixit, M. N. (Univ. New Brunswick, Fredericton, New Brunswick).

Can. J. Phys. 1968, 46(18), 2079-86 (Eng).

54. Correction to "Transition probabilities for some argon II laser states."

Koster, G. F.; Statz, H.; Horrigan, F. A.; Tang, C. I. (Mqssachusetts Inst. of Technol., Cambridge, Mass.).

J. Appl. Phys. 1968, 39(8), 4045-6 (Eng); ef. S., et al., 1965.

55. Photoionization of high-temperature vapors. IV. Thallous fluoride, thallous chloride, and thallous bromide. Berkowitz, J.; Walter, T. A.(Argonne Nat. Lab., Argonne, Ill.). J. Chem. Phys. 1968, 49(3), 1184-9 (Eng). 
A. 56. Atomic absorption spectroscopy.

Van der Linden, J. G. M.

Instrum. Rev. (Leiden) 1967, 2ji/5, 34-8 (Neth).

57. Line sources for use in atomic fluorescence flame spectrometry. Mansfield, Joseph Minor, Jr. (Univ. of Florida, Gainesville, Fla.). 1967, 150 pp. (Eng). Avail. Univ. Microfilms, Ann Arbor Mich., Order No. 68-9537. From Diss. Abstr. B 1968, 29(1), 79-80.

58. Gas reactions yielding electronically excited species.

Thrush, B. A. (Univ. Cambridge, Cambridge, Engl.).

Annu. Rev. Phys. Chem. 1968, 19, 371-88 (Eng).

59. Regularities in atomic oscillator strengths.

Weise, W. L.; Weiss, A. W. (Nat. Bur of Stand., Washington, D. C.). Phys. Rev. 1968, 175(1), 50-65 (Eng).

60. Direct predissociation of molecular iodine B $3 \mathrm{II}_{\mathrm{Ou}+}$. wasserman, E.; Falconer, W. E.; Yager,W. A. (Bell Teleph. Lab., Inc., Murray Hill, N. J.).

J. Chem. Phys. 1968, 49(4), 1971-2 (Eng).

61. Electronically excited metastable states of molecules with an ultrahigh-vacuum molecular beam apparatus.

Clampitt, R.; Newton, Amos S. (Lawrence Radiat. Lab., Univ. of California, Berkeley, Calif.). U. S. At. Energy Comm. 1967, UCRI-18032 53 pp. (Eng). Avail. Dept.; DFSTI. From Nucl. Sci. Abstr. 1968, 22(12), 24027.

62. Dissociation energy of diatomic manganese.

Kant, Arthur; Lin, Sin-Shong, Strauss, Bernard (Army Mater. and Mech. Res. Center, Watertown, Mass.).

J. Chem. Phys. 1968, 49(4), 1983-5 (Eng).

63. Proof of two conjectures of Mulliken concerning the electronic energy of diatomic molecules for small R.

Bingel, Werner A. (Univ. Goettingen, Goettingen, Ger.).

J. Chem. Phys. 1968, 49(4), 1931-4 (Eng).

64. Metastable atoms and molecules. III. Metastable impacts on surfaces with various workfunctions.

Varney R. N. (Lockheed Palo Alto Res. Lab., Palo Alto, Calif.) Phys. Rev. 1968, 175(1), 98-102 (Eng).

65. Relative brightnesses and optical excitation functions of some spectral lines of mercury.

Bogdanova, I. P.; Marusin, V. D. (USSR). Opt. Spektrosk, 1968, 25(2), 319-21 (Russ). CA Vo1. 69, 101144 (1968). 
A. 66. Observation and characterization of a new band of the molecule $\mathrm{HBr}^{+}\left(2 \Sigma^{+} \rightarrow{ }^{2} I I_{i}\right)$. Fine structure of the $(0-2)$ band of this transition.

Marsigny, Louis; Lebreton, Joseph; Ferran, Jacques; Lagrange, Rene (Coll. Sci. Univ. Tours, Tours-Grandmount, Fr.). C. R. Acad. Sci., Paris, Ser. C 1968, 266(26), 1731-2 (Fr).

67. Spectra of ions of iron-group elements.

Grabauskas, D. ; Vizbaraite, J.; Jucys, A. (Vil'nyus. Gos. Univ. im. Kapsukas, Vilnius, USSR).

Liet. Fiz. Rinkinys, Liet. TSR Mokslu Akad., Liet. TSR Aukst. Mokyklos 1967, 7(3), 567-82 (Russ). CA Vol. 69, 101156k (1968).

68. Spectra of titanium II and vanadium III in excited configurations. Grabauskas, D.; Vizbaraite, J.; Jucys, A. (Vil'nyus. Gos. Univ. im. Kapsukas, Vilnius, USSR).

Liet F'iz. Rinkinys, Liet. TSR Mokslu Akad., Liet TSR Aukst. Mokyklos 1967, 7(3), 583-95 (Russ). CA Vol. 69, 101157m (1968).

69. Spectra of cobalt I, nickel II, and copper III in excited configurations.

Grabauskas, D.; Vizbaraite, J.; Jucys, A. (Vil'nyus. Gos. Univ. im. Kapsukas, Vilnjus, USSR).

Liet Fiz. Rinkinys, Liet. TSR Mokslu Akad., Liet. TSR Aukst. Mokyklos 1967, 7(3), 597-609 (Russ). CA Vol. 69, 101158n (1968).

70. Transition probabilities of argon I in the range of 5000-6500 A. and the role of a nonuniform source temperature.

Desai, S. V.; Corcoran, W. H. (California Inst. of Technol., Pasadena, Calif.).

J. Quant. Spectrosc. Radiat. Transfer 1968, 8(10), 1721-30.

71. Intense vacuum ultraviolet atomic line sources.

Davis, Douglas; Braun, Walter (Nat. Bur. of Stand., Washington, D.C.). Appl. Opt. 1968, 7(10), 2071-4.

72. Absorption spectrum of $\mathrm{PH}$ in the vacuum ultraviolet. Balfour, W. J.; Doublas, A. E. (Div. Pure Phys., Nat. Res. Counc. Canada, Ottawa, Can.).

Can. J. Phys. 1968, 46(20), 2277-80.

73. New band system of copper hydride in the far ultraviolet. Ringstroem, Ulf (Div. Pure Phys., Nat. Res. Counc. Canada, Ottawa, Can.).

Can. J. Phys. 1968, 46(20), 2291-300. 
A. 74. [Absorption bands of ] the $\mathrm{O}^{+}{ }^{1} \sum^{+}$system of ${ }^{35} \mathrm{ClF} /{ }^{37} \mathrm{ClF}$ in the visible region.

Stricker, Winfried; Krauss, L. (DVL-Inst. Raketentreibstoffe, Stuttgart-Vaihingen, Ger.).

Z. Naturforsch., A 1968, 23(8), 1116-21 (Ger.).

75. Emission spectrum of the A-X system of BiBr molecule. Singh, S. P. (Banaras Hindu Univ., Varanasi, India). Indian J. Pure Appl. Phys. 1968, 6(6), 299-301.

76. Rotational analysis of the blue-green system of scandium oxide. Adams, Annabel; Klemperer, W. ; Dunn, T. M. (Harvard Univ., Cambridge, Mass.).

Can. J. Phys. 1968, 46(19), 2213-20.

77. Relative values of transition probabilities in doublets of the principal series of scandium III, yttrium III, and lanthanum III spectra.

Kunisz, M. D.; Lubowiecka, T.; Muryn, A.; Niziol, E. ; Szynarowska, M. (Jagellonian Univ., Cracow, Poland).

Acta Phys. Pol. 1968, 33(4), 665-71.

78. Spectra of xenon and krypton arcs.

Newell, P. Bruce; O-Brien, John D. (EG and G, Inc., Bedford, Mass.).

IEEE J. Quantum Electron. 1968, 4(5), 291-3.

79. Vibrational analysis of ${ }^{2} \Sigma-{ }^{2} I I$ system of $\mathrm{GeCl}$.

Filippova, A. P.; Kuzyakov, Yu. Ya. (USSR).

Vestn. Mosk. Univ., Khim. 1968, 23(3), 25-9 (Russ). CA Vol. 69, 101409v (1968).

80. Measurement of the lifetime of the $6^{3} \mathrm{~S}_{1}$ level of cadmium and of the collision cross sections of various gases for this level. Laniepce, B. (Lab. Spectrosc. At., Fac. Sci. Caen, Caen, Fr.). J. Phys. (Paris) 1968, 29(5-6), 427-33 (Fr).

81. Radiance lifetimes in the resonance series of argon I. Lawrence, George M. (Douglas Advan. Res. Lab., Huntington Beach, Calif.).

Phys. Rev. 1968, 175(1), 40-4.

82. Fluorescence and phosphorescence of sulfur dioxide vapor. Mettee, H. D. (Univ. of Texas, Austin, Tex.).

J. Chem. Phys. 1968, 49(4), 1784-93.

83. Iuminescence and radiations transitions in sulfur dioxide gas. Strickler, S. J.; Howell, Daniel B. (Univ. of Colorado, Boulder, Colo.).

J. Chem. Phys. 1968, 49(4), 1947-51. 
A. 84. Radiative mean-life measurements of some atomic hydrogen excited states using beam-foil excitation.

Chupp, E. L. ; Dotchin, I. W. ; Pegg, D. J. (Univ. of New Hampshire, Durham, N. H.).

Phys. Rev. 1968, 175(1), 44-50.

85. Neon transition probabilities.

Lilly, Roger A.; Holmes, J. R. (Univ. of Hawaii, Honolulu, Hawaii).

J. Opt. Soc. Amer. 1968, 58(10), 1406-9.

86. Photoionization of ytterbium: 1350-2000 A.

Parr, Albert C.; Elder, Fred A. (Univ. of Chicago, Chicago, Ill.). J. Chem. Phys. 1968, 49(6), 2665-7.

87. Mass spectrometric study of photoionization. Cyanogen and the cyanogen halides.

Page, F. M. (Univ. Aston, Birmingham, Engl.).

J. Chem. Phys. 1968, 49(5), 2466.

88. Atomic oscillator strengths. IV. Transitions of the type $s^{2}-s p$ Warner, Brian (Univ. of Texas, Austin, Tex.).

Mon. Notic, Roy. Astron. Soc. 1968, 140(1), 53-9 (Eng).

89. Statistical theory of dissociation and recombination for moderately complex molecules.

Keck, James; Kalelkar, Ashok (Massachusetts Inst. of Technol., Cambridge, Mass.).

J. Chem. Phys. 1968, 49(7), 3211-23 (Eng).

90. Jacobi-Gauss quadrature calculations of Rydberg-Klein potential energy curves for diatomic molecules and solutions of the ensuring wave equations and some of their bound states. McKeever, J. W.; Schweinler, H. C. (Oak Ridge Gaseous Diffus. Plant, Oak Ridge, Tenn.).

U. S. At. Energy Comm. 1968, ORNL-TM-2167, 170 pp. (Eng). Avail. Dep.; CFSTI. From Nucl. Sci. Abstr. 1968, 22(14), 29178.

91. Chemiluminescence in gases: reactions yielding electronically excited sulfur dioxide.

Thrush, B. A.; Halstead, C. J.; McKenzie, A. (Univ. Cambrige, Cambridge, Engl.).

J. Phys. Chem. 1968, 72(11), 3711-14 (Eng).

92. Stacking-fault densities in hexagonal ( $\beta$-phase) silver-antimony alloys.

De, M.; Sen, S. (Indian Assoc. Cultiv. Sci., Calcutta, India). Brit. J. Appl. Phys. 1968, [2]1 (9), 1141-4 (Eng).

93. Potential energy curves of the ${ }^{I} I I$ and $I_{\Sigma^{+}}$states of the $B C I$ molecule.

Genebart, Francois; Johannin-Gilles, Andree (Fac. Sci. Brest, Brest, Fr.) C. R. Acad. Sci., Paris, Ser. A,B 1968, 267B (6), 408-11 (Fr). 
A. 94. New high-resolution analysis of several bands of the $D \rightarrow X$ system of the As? molecule.

Perdigon, Pierre; D'Incan, Jean; Janin, Joseph (Univ. Lyon, Villeurbanne, Fr.).

C. R. Acad. Sci., Paris, Ser. A, B 1968, 267B(3), 202-4 (Fr).

95. Molecular radiation from high-pressure discharges. Mercury-tin (II) iodide arc.

Zollweg, R. J.; Frost, I. S. (Westinghouse Res. Lab., Pittsburgh, Pa.).

Phenomena Ioniz. Gases, Int. Conf. Contrib. Pap., 8th Vienna 1967 224 (Eng).

96. Experimental lifetimes of the 5p levels in argon $I$.

Klose, Jules A. (Nat. Bur. of Stand., Washington, D. C.).

J. Opt. Soc. Amer. 1968, 58(11), 1509-12 (Eng).

97. Ultraviolet absorption spectra of gaseous tin difluoride and lead difluoxide.

Hauge, Robert H.; Hastie, J. W.; Margrave, J. I. (Rice Univ., Houston, Tex.).

J. Phys. Chem. 1968, 72(10), 3510-11 (Eng).

98. Diffuse spectra of $\mathrm{SeH}$ and SeD.

Lindgren, Bo (Univ. Stockholm, Stockholm, Swed.).

J. Mol. Spectrose. 1968, 28(4), 536-9 (Eng).

99. Infrared spectra of the vapors above rhenium heptaoxide and sodium, potassium, rubidium, and cesium perrhenates, tetrahedrally coordinated rhenium compounds.

Spoliti, M.; Stafford, F. E. (Northwestern Univ., Evanston, Ill.). Inorg. Chim. Acta 1968, 2(3), 301-4 (Eng).

100. Hyperfine structure of the transition silver $I, \lambda=19,372 \mathrm{~A}$. Fischer, Wolfgang; Huehnermann, Harry; Krueger, Ekkehard (Univ. Marburg/Lahn, Marburg/Lahn, Ger.).

Z. Phys. 1968, 216(2), 136-41 (Ger).

101. Frank-Condon factors and $r$ centroids for the B-X and C-X systems of the MgF molecule.

Maheshwari, R. C.; Singh, I. D.; Shukla, M. M. (Gorakhpur Univ. Gorakhpur, India).

Proc. Phys. Soc., London, At. Mol. Phys. 1968, [2] I(5), 993-6 (Eng)

102. Fine structure of the $\mathrm{C}_{2}$ high-pressure bands.

Meinel, H.; Messerle, G. (Deut. Versuchst. Luft-Raumfahrt, Stuttgart, Ger.).

Astrophys. J. 1968, 154(1) (Pt. 1), 381-4. 
103. Measurement and identification of laboratory-produced vacuum ultraviolet spectral lines.

Roth, Nancy V.; Elton, R. C. (Nav. Res. Lab., Washington, D. C.). U. S. Clearirghouse Fed. Sci. Tech. Inform. 1968, AD 667584, $41 \mathrm{pp}$ (Eng.) Avail. CFSTI. From U. S. Govt. Res. Develop. Rep. 1968 68(11), 114 .

104. Band spectrum of mercury bromide in the ultraviolet region. Patel, M. M.; Darji, A. B. (M. S. Univ. Baroda, Baroda, India). Indian J. Phys. 1968, 42(2), 110-19 (Eng).

105. Spectroscopic research on a thermal plasma of copper vapor. Weniger, S. (Observ. Paris, Meudon, Fr.).

Phenomena Ioniz. Gases, Int. Conf., Contrib. Pap., 8th, Vienna 1967, 457 (Eng).

106. Argon absorption in the vacuum ultraviolet using the helium recombination continuum from plasma arc source. Levy, M. E.; Huffman, R. E. (Vitro Lab., West Orange, N. J.). Phenomena Ioniz. Gases, Int. Conf., Contrib. Pap., 8th, Vienna 1967, 456 (Eng).

107. Electronic systems of the PO radical. IV. Visible and ultraviolet systems associated with the $D^{2} I I_{r}(a)$ and $D^{\prime 2} I I_{r}(a)$ states. Couet, Claude; Coquart, Bernard; Ngo Tuan Anh; Guenebaut, Henri (Lab. Chim. Phys., Fac. Sci., Reims. Fr.). J. Chim. Phys. Physicochim. Biol. 1968, 65(7), 124l-58 (Fr).

108. Spectrum of copper oxide; study of the orange-red system by use of oxygen-18.

Antic-Jovanovic, A.; Pesic, D. S.; Gaydon, A. G. (Inst. Nucl. Sci., Belgrade, Yugoslavia).

Proc. Roy. Soc., Ser. Al968, 307 (1491), 399-406 (Eng).

109. Radiative lifetimes for nitrogen II ultraviolet multiplets. Hesser, James E.; Lutz, Barry I. (Princeton Univ., Observ., Princeton, N. J.).

J. Opt. Soc. Amer. 1968, 58(11), 1513-15 (Eng).

110. Production of $\mathrm{N}_{2}\left(\mathrm{~A}{ }^{3} \Sigma_{\mathrm{u}}{ }^{+}\right)$and $\mathrm{CO}(\mathrm{a} 3 \pi)$ by $\mathrm{Hg}\left(\mathrm{I}_{\mathrm{P}_{1}}\right)$ photosensitization: evidence from 2537-A. mercury scintillation. Granzow, Albrecht; Hoffman, Morton Z.; Lichtin, Norman N.; Wason, Satish K. (Boston Univ., Boston, Mass.). J. Phys. Chem. 1968, 72(11), 3741-6 (Eng).

11l. Absorption spectrum of the free $\mathrm{SiH}_{2}$ radical. Dubois, Iwan (Div. Pure Phys., Nat. Res. Counc., Ottawa, Can.). Can. J. Phys. 1968, 46(22), 2485-90 (Eng). 
A. 112. Extension of the $F^{2} \sum \rightarrow X^{2} \sum$ system of $\mathrm{BaH}$ and $\mathrm{BaD}$. Khan, M. Aslam (Univ. Karachi, Karachi, Pakistan).

Proc. Phys. Soc., London, At. Mol. Phys. 1968, [2]1(5), 985-9

113. Effect of the characteristics of light beam for detecting the modulated absorption and dispersion signals of mercury-201 vapor. Laloe, Franck Leduc, Michele Minguzzi, Paolo (Lab. Spectrosc. Hertzienne, E. N. S., Fac. Sci., Paris, Fr.).

C. R. Acad. Sci., Paris, Ser. A,B 1968, 267B (5), 328-31 (Fr).

114. New spectrum associated with diatomic carbon.

Herzberg, G. Lagerqvist, A. (Div. Pure Phys., Nat. Res. Counc. Canada, Ottawa, Can.).

Can. J. Phys. 1968, 46(21), 2363-73 (Eng).

115. Isotope shifts in the second negative band of $\mathrm{O}_{2}{ }^{+}$[molecular oxygen positive ions].

Bhale, G. L. Rao, P. Ramakoteswara (Spectroscopy Div., Bhabha At. Res. Centra, Trombay, India).

Proc. Indian Acad. Sci., Sect. A 1968, 67(6), 350-7 (Eng).

116. Absorption coefficients of oxygen at the Lyman-c line and its vicinity.

Ogawa, M. (Univ. of Southern California, Los Angeles, Calif.). J. Geophys. Res. 1968, 73(21), 6759-63 (Eng).

117. Low-frequency spectra of lithium halide molecular species. Freiburg, M.; Ron, A.; Schnepp, O. (Israel Inst. Technol., Haifa, Israel).

J. Phys. Chem. 1968, 72(10), 3526-31 (Eng).

118. New data concerning the broadening and shift of Ar I and Ar II spectral lines in a spark plasma. Iova, Iancu (Univ. Bucharest, Bucharest, Rom.). Rev. Roum. Phys. 1968, 13(3), 267-73 (Eng).

119. Analysis of the vibrational structure of the $\mathrm{SiBr}$ emission spectrum.

Kuznetsova, I. A.; Kuz'menko, N. E.; Kuzyakov, Yu. Ya. (USSR). Vesth. Mosk. Univ., Khim. 1968, 23(3), 30-5 (Russ), CA Vol. 69 111768 (1968).

120. Isotope shift in the resonance lines of cesium-131. Huehnermann, Harry; Wagner, Hermann (Univ. Marburg, Marburg, Ger. Z. Phys. 1968, 216(1), 28-32 (Eng). 
121. Differentiation between holmium II spectra using only a d.c. arc as excitation source.

Held, Sima (Israel At. Energy Com., Tel-Aviv, Israel). Israel At. Energy Comm. 1968, 1A-1162, 65 pp (Eng).

122. Emission spectrum of zinc bromide in the visible region.

Patel, M. M.; Rajan, K. Jacob (M. S. Univ. Baroda, Baroda, India). Indian J. Phys. 1968, 42(2), 125-30 (Eng).

123. The $\mathrm{c}^{\mathrm{I} I I-b{ }^{+}} \Sigma^{+}$band system of $\mathrm{NH}$ and $\mathrm{ND}$.

Whittaker, F. I. (Imp. Coll., Iondon, Engl.)

Proc. Phys. Soc., London, At. Mol. Phys. 1968, [2] 1(5), 977-82.

124. Participation of metastable states of certain atoms in their excitation processes by a spectrographic arc under the normal pressure of a monatomic gas.

Bril, Jacques; Dieudonne, Hubert (Centre Rech. Groupe Pechiney, Voreppe, Fr.).

C. R. Acad. Sci. Paris, Ser. A,B 1968 267B(5), 321-4 (Fr).

125. Predissociation of chemiluminescent $\mathrm{OH}$ and $\mathrm{OD}$.

Palmer, H. B.; Naegeli, D. W. (Pennsylvania State Univ., University Park, Pa.).

J. Mol. Spectrose. 1968, 28(4), 417-21 (Eng).

126. Decay of helium metastable atoms in àterglow.

Sadeghi, N.; Pebay-Peyroula, J. C. (Lab. Phys. Gen., Grenoble, Fr.).

Phenomena Ioniz. Gases, Int. Conf., Contrib. Paf., 8th, Vienna 1967, 51 (Eng).

127. Lifetime measurements of the $4 \mathrm{~s}^{2} \mathrm{~S}_{1} / 2$ and $3 \mathrm{~d}^{2} \mathrm{D}$ states of aluminum by the phase-shift method. Cummingham, Paul T. (Lawrence Radiat. Lab., Univ. of California, Berkeley, Calif.). J. Opt. Soc. Amer. 1968, 58(I1), 1507-9 (Eng).

128. Chemiluminescent emission in gaseous reactions at low concentrations. Emerson, John; Reeves, Robert: Harteck, Paul (Mason Lab., Rensselaer Polytech. Inst., Troy, N. Y.). J. Phys. Chem. 1968, 72(11), 3721-4 (Eng).

129. Formation of electronically excited species in nitrogen atomoxygen atom recombination reactions catalyzed by carbon compounds: $\operatorname{NO}\left(A^{2} \Sigma, B^{2} I I\right)$ and $O\left(I_{S}\right)$. Fontijn, Arthur; Ellison, Roy (AeroChem Res. Lab., Inc., Princeton, I.J.).

J. Phys. Chem. 1968, 72(10), 3701-2 (Eng). 
A. 130. Oxygen-argon afterglow as a source of the $\mathrm{O}_{2}\left(\mathrm{~A}^{3} \Sigma \mathrm{u}^{+}-\mathrm{X}^{3} \Sigma_{\mathrm{g}}{ }^{-}\right)$ Herzberg I band system.

Degen, V.; Nicholls, R.W. (York Univ., Toronto, Ont.)

Proc. Phys. Soc., London, At. Mol. Phys. 1968, [2]1(5), 983-4.

131. Pressure broadening of the 60-GHz. microwave lines of oxygen. Abbott, Richard Lawrance (Univ. of Colorado, Boulder, Colo.). 1967, $131 \mathrm{pp}$. (Eng). Avail. Univ. Microfilms, Ann Arbor, Mich. Order No. 68-10,599. From Diss. Abstr. B 1968, 29(2), 719-20.

132. Hyperfine structure of the rotational spectrum of hydrogen iodide in the submillimeter region.

Van Dijk, F. A.; Dymanus, A. (Katholieke Univ. Nijmegen, Nijmegen, Neth.).

Chem. Phys. Lett. 1968, 2(4), 235-6 (Eng).

133. Calculation of the radiative lifetime of the $a^{4}$ II state of nitric oxide.

Lefebvre-Brion, H.; Guerin, F. (Centre Mec. Ondulatoire Appl., Paris, Fr.).

J. Chem. Phys. 1968, 49(3), 1446-7 (Eng).

134. Nuclear magnetic dipole moment of holmium-165.

Sugar, Jack (Nat. Bur. of Stand., Washington, D. C.).

J. Opt. Soc. Amer. 1968, 58(11), 1519-23 (Eng).

135. Level-crossing investigation of the hyperfine structure of the excited $3^{2} \mathrm{P}_{3} / 2$ and $4{ }^{2} \mathrm{P}_{3 / 2}$ state of sodium-23.

Schoenberner, Detlef; Zimmermann, Di eter (Tech. Univ. Berlin, Berlin, Ger.).

Z. Phys. 1968, 216(2), 172-82 (Ger).

136. Catalog of Emission Lines in Astrophysical Objects.

Meinel, Aden B.; Aveni, Anthony F.; Stockton, Martha W. (Optical Sci. Center, Univ. of Arizona: Tucson, Ariz.). 1968, 162 pp.

137. Some fast reactions in gases studied by flash photolysis and kinetic Spectroscopy.

Norrish, Ronald G. W. (Cambridge Univ., Cambridge, Engl.). Prix Nobel 1967, (Pub. 1968), 181-211 (Eng).

138. Flash photolysis and primary processes in the excited state. Porter, G. (Roy. Inst., London, Engl.).

Fast React. Primary Processes Chem. Kint., Proc. Nobel Symp., 5th 1967, 141-61 (Eng).

139. Pulsed-radiolysis study of atomic oxygen reactions in the gas phase.

Meaburn, G. M.; Perner, D.; LeCalve, J.; Bourene, M. (C.E.N. Saclay, Saclay, Fr.).

J. Phys. Chem. 1968, 72(11), 3920-5 (Eng). 
A. 140. Examination of the operating conditions for hollow cathode lamps and selection of analysis lines. I. Westinghouse lamps for $\mathrm{Ca}, \mathrm{Co}, \mathrm{Pb}, \mathrm{Mn}, \mathrm{K}$, and $\mathrm{Na}$. Murata, Noboru (Dainippon Ink Chem., Inc., Tokyo, Japan). Burseki Kagaku 1968, 17(8), 1002-11 (Japan).

141. Examination of the operating conditions for hollow cathode lamps and selection of analysis lines. II. Westinghouse lamps for $\mathrm{Ba}$, îe, $\mathrm{Mg}, \mathrm{Sn}$, and $\mathrm{Zn}$. Murata, Noboru (Dainippon Ink Chem., Inc., Tokyo, Japan). Bunseki Kagaku 1968, 17(8), 1012-19 (Japan).

142. Depolarizing collisions of excited thallium atoms with inert gases.

Teplova, S.; Chaika, M. P.; Cherenkovskii, V. A. (USSR). Opt. Spektrosk. 1968, 25(3), 349-9 (Russ). CA Vol. 69, 6609 (1968).

143. Configuration interaction study of the four lowest ${ }_{\Sigma^{+}}^{+}$states of the lithium hydride molecule.

Brown, Richard Edwin; Shull, Harrison (Indiana Univ., Bloomington, Indiana).

Int. J. Quantum Chem. 1968, 2(5), 663-85 (Eng).

144. Dissociation Energies and Spectra of Diatomic Molecules.

Gaydon, Alfred G. (Barnes and Noble: New York). 1968, 330 pp.

145. Rapid scanning with the Fabry-Perot etalon.

Greig, J. R.; Cooper, John (Univ. of Maryland, College Park, Md). Appl. Opt. 1968, 7(11), 2166-70 (Eng).

146. Rapid advances in rapid-scan spectroscopy.

Rimentel, George C. (Univ. of California, Berkeley, Calif.). Appl. Opt. 1968, 7(11), 2155-60 (Eng).

147. Experimental determination of radiation lifetimes and transition probabilities in argon $I$.

Verolainen, Ya. F.; Osherovish, A. L. (USSR).

Opt. Spektrosk. 1968, 25(3), 466-8 (Russ). CA Vol. 69, 7602 (1968).

148. Franck-Condon factors and $r$-centroids for $\left(A^{2} I I-X^{2} \Sigma\right)$ system of $\mathrm{BeF}$ molecule.

Katti, M. R.; Sharma, H. D. (Appl. Phys. Div., Def. Sci. Lab., Delhi, India).

Indian J. Pure Appl. Phys. 1968, 6(8), 458 (Eng). 
A. 149. Spectrum of triply ionized nickel (Ni IV).

Poppe, R. (Univ. Amsterdam, Amsterdam, Neth.).

Physica 1968, 40(1), 17-26 (Eng).

150. Low-noise solar and laboratory spectroscopy. III. The lead I 7229-A. line and the solar lead abundance.

Reach, F. V. (Univ. Observ., Oxford, Engl.).

Mon. Notic. Roy. Astron. Soc. 1968, 140(1), 43-51 (Eng).

151. Franck-Condon factors and $r$-centroids for the $C \rightarrow X$ band system of the ${ }^{12 \mathrm{CH}}$ molecule.

Sharma, Devendra; Singh, P. D.; Pathak, A. N. (Univ. Gorakhpur, Gorakhpur, India).

Indian J. Pure Appl. Phys. 1968, 6(8), 443-5 (Eng).

152. Band spectrum of diatomic cadmium iodide in the visible region 4130-4800 A.

Patel, Madhubhai M.; Patel, Suryakant P.; Darji, A. B. (Maharaja Sayajiroa Univ. Baroda, Baroda, India).

Indian J. Pure Appl. Phys. 1968, 6(7), 342-3 (Eng).

153. Electronic states of fluorides of scandium, yttrium, and lanthanum. Barrow, R. F.; Bastin, M. W.; Moore, D. I. G•; Pott, C. J. (Univ. Oxford, Oxford, Engl.). Nature 1967, 215(5105), 1072-3 (Eng).

154. Vibrational transition probabilities and r-centroids of diatomic molecules: band systems of $\mathrm{CuCl}$.

Rao, D. V.; Nair, K. P. R.; Rai, D. K. (Banaras Hindu Univ•, Varanasi, India).

Indian J. Pure Appl. Phys. 1968, 6(7), 396-7 (Eng).

155. Forbidden vibrational transitions in the electron-impact spectra of molecular oxygen and nitrogen.

Skerbele, Ausma; Dillon, Michael A.; Lassettre, Edwin N. (CarnegieMellon Univ., Pittsburgh, Pa.).

J. Chem. Phys. 1968, 49(8), 3543-5 (Eng).

156. Rotational analysis of the bands of the A'-X system of BiCl molecules. Mohanty, B. S.; Nair, K. P. R.; Upadhya, K. N. (Banaras Hindu Univ., Banaras, India).

Indian J. Pure Appl. Phys. 1968, 6(9), 494-6 (Eng).

157. Dependence of vibrational grequency of diatomic molecules on electronegativity.

Singh, Surendra, P.; Mathur, Veerendra, K. (Kurukshetra Univ•, Kurukshetra, India).

Indian J. Pure Appl. Phys. 1968, 6(7), 386-8 (Eng). 
A. 158. Rapid recording microspectrophotometer.

Wolken, Jerome J.; Forsberg, R.; Gallik, G.; Florida, R.

(Carnegie-Mellon Univ., Pittsburgh, Pa.).

Rev. Sci. Instrum. 1968, 39 (II), 1734-40 (Eng).

159. Double-beam absorption spectrophotometer for far ultraviolet radiation.

Castex, M. C.; Monlouis, P.; Romand, J. (Lab. Hautes Pressions, C. N. R. S., Bellevue, Fr.).

Rev. Phys. Appl. 1968, 3(2), 175-84 (Fr.).

160. Analysis of band spectra.

Berflinger, G.; Lischka, H. (Univ. Wien, Vienna, Austria). Monatsh. Chem. 1968, 99 (5), 1851-65 (Ger).

161. Faraday rotation studies of $F$ centers in alkaline earth oxides. Bessent, Rodney G.; Cavenett, B. C.; Hunter, Ian C. (Solid. State Phys. Div., At. Energy Res. Estab., Harwell, Engl.). J. Phys. Chem. Solids 1968, 29(9), 1523-30 (Eng).

162. Experimental determination of the oscillator strengths for some transitions in the Lyman bands of molecular hydrogen. Haddad, G. N. ; Lokan, K. H.; Farmer, A. J. D.; Carver, J. H. (Univ. Adelaide, Adelaide, Aust.).

J. Quant. Spectrosc. Radiat. Transfer 1968, 8(5), 1193-200 (Eng).

163. Mean life of the $6^{l} \mathrm{P}$ mercury level. Coherent multiple scattering of the 1850-A. optical resonance light.

Lecler, D. (Lab. Spectro. At., Fac. Sci., Caen, Fr.). J. Phys. (Paris) 1968, 29(7), 611-18 (Fr).

164. Band spectrum of BaD.

Kopp, Ingvar; Wirhed, Rolf (Univ. Stockholm, Stockholm, Swed.). Ark. Fys. 1968, 38(15), 277-307 (Eng).

165. Rotational analysis of bands of the gaseous AgAl molecule.

Clements, R. M.; Barrow, Richard F. (Oxford Univ., Oxford, Engl.). Trans. Faraday Soc. 1968, 64(11), 2893-5 (Eng).

166. Electronic absorption spectrum of the NCS free radical.

Dixon, Richard N.; Ramsay, Donald A. (Univ. Sheffield, Sheffield, Engl.).

Can. J. Phys. 1968, 46(23), 2619-31 (Eng).

167. New classifications in selected ionic spectra of nickel, copper, and zine.

Even-Zohar, Moshe; Fraenkel, Benjamin S. (Hebrew Univ., Jerusalem, Israel).

J. Opt. Soc. Amer. 1968, 58(10), 1420-1 (Eng). 
A. 168. A note on the rotational analysis of the A-X system of the lead monobromide molecule.

Lal, K. M.; Khanna, B. N. (Aligarh Muslim Univ., Aligarh, India) . Can J. Phys. 1968, 46(17), 1991-2 (Eng).

169. Excitation of spark spectra of sulfur and chlorine in an atmosphere of various gases.

Berezin, I. A.; Korpushev, A. I.; Razuvaev, V. A. (USSR) . Zh. Prikl. Spektrosk. 1968, 9(1), 14-17 (Russ). CA Vol. 69, 7810 (1968).

170. Survey of the first spectrum of protactinium.

Richards, E. W. T.; Stephen, I.; Wise, H. S. U. K. At. Energy Auth., Res. Group, At. Energy Res. Estab., Rep. 1968, AERE-R573I, 159 pp. (Eng). Avail. HMSO. 21 s.

171. Spectroscopic study of excited states in an argon plasma. Frost, Milton A., III; Wierum, Frederic A., Jr. (Gen. Dyn., Fort Worth, Tex.).

AIAA(Amer. Inst. Aeronaut. Astronaut.) J. 1968, 6(10), 2043-4 (Eng).

172. Emission spectrum of lead bromide molecule.

Singh, Surendra P. (Kurukshetra Univ., Kurukshetra, India). Indian J. Pure Appl. Phys. I968, 6(7), 384-5 (Eng).

173. Emission spectrum of BiI molecule.

Singh, Surendra PaI (Banaras Hindu Univ., Varanasi, India). Indian J. Pure AppI. Phys. I968, 6(8), 445-6 (Eng).

174. Intensity law for microwave spectroscopy: theoretical and experimental.

Harrison, Howard W. (Hewlett-Packard Co., Palo Alto, Calif.). J. Chem. Phys. 1968, 49(7), 3023-35 (Eng).

175. Shock-tube determination of the electronic transition moment of the $\mathrm{C}_{2}$ (Swan) bands.

Arnold, James O. (Ames Res. Center, NASA, Moffett Field, Calif.). J. Quant. Spectrosc. Radiat. Transfer 1968, 8(II), 1781-94 (Eng).

176. Structure of triply ionized nickel (Ni IV).

Garcia-Riquelme, Olga (Inst. Opt., Madrid, Spain). Physica 1968, 40 (I), 27-9 (Eng).

177. Laser photolysis and spectroscopy: a new technique for the study of rapid reactions in the nanosecond time range.

Novak, J. R.; Windsor, Maurice W. (Chem. Sci. Dept., TRW Systems, Redondo Beach, Calif.).

Proc. Roy. Soc., Ser. A 1968, 308(1492), 95-110 (Eng). 
A. 178. Selective excitation spectroscopy and some possible applications. Measures, R. M. (Univ. Toronto, Toronto, Can.). J. Appl. Phys. 1968, 39(11), 5232-45 (Eng).

179. Electronic scanning spectrometer for measurements of rapidy changing spectra.

Baker, Doran J.; Steed, Allan J. (Utah State Univ., Logan, Utah). Appl. Opt. 1968, 7(Il), 2190-4 (Eng).

180. Rapid-scan spectrometers for the diagnostics of transient plasma. Hill, Ronald Amer (Sandia Lab., Albuquerque, N. Mex.). Appl. Opt. 1968, 7(11), 2184-9 (Eng).

181. Wide-range, rapid-scanning spectrometer for emmission and absorption measurements. Buchhave, P.; Church, Charles H. (Westinghouse Res. Lab., Pittsburgh, Pa.).

Appl. Opt. 1968, 7(II), 2200-4 (Eng).

182. Rapid-scan flash spectrophotometer with a flying-spot light source and magnetic storage.

Koszewski, Jozef; Jasny, Jan; Grabowski, Zbigniew R. (Polska Akad. Nauk, Warsaw, Poland). Appl. Opt. 1968, 7(11), 2178-83 (Eng).

183. Formation, reaction, and deactivation of molecular oxygen $\left(I_{\Sigma_{g}^{+}}^{+}\right)$ Izod, T. P. J.; Wayne, Richard P. (Phys. Chem. Lab., Oxford, Engl.).

Proc. Roy. Soc., Ser. A 1968, 308(1492), 81-94 (Eng).

184. Absolute measurement of argon II $4 \mathrm{p}^{4} \mathrm{~S}^{0} 3 / 2$ state lifetime by the correlation of photons emitted during cascade.

Camhy Val, Claude; Dumont, Anne Marie (Inst. Astrophys., Paris, Fr.).

C. R. Acad. Sci., Paris, Ser. A,B 1968, 267B(15), 689-91 (Fr.).

185. Electronic transition moment integrals for first ionization of $\mathrm{CO}$ and the A-X transition in $\mathrm{CO}^{+}$. Some limitations on the use of the r-centroid approximation.

Krupenie, Paul H.; Benesch, William (Inst. for Basic Stand., Nat. Bur. of Stand., Washington, D. C.).

J. Res. Nat. Bur. Stand., Sect. A 1968, 72(ct), 495-503 (Eng).

186. Computed ground state properties of beryllium oxide, magnesium oxide, calcium oxide, and strontium oxide in molecular orbital approximation.

Yoshimine, Megumu (Kyushu Univ., Fukuoka Japan).

J. Phys. Soc. Jap. 1968, 25(4), 1100-19 (Eng). 
A. 187. Core polarization corrections to oscillator strengths in the alkali atoms.

Hameed, S.; Herzenberg, A.; James, M. G. (Univ. Manchester, Manchester, Engl.).

Proc. Phys. Soc., London, At. Mol. Phys. 1968, [2] 1 (5), 822-30.

188. Recombination of ground state halogen atoms. II. Kinetics of the overall recombination of chlorine atoms.

Clyne, Michael A. A.; Stedman, D. H. (Queen Mary Coll., London Engl.).

Trans. Faraday Soc. 1968, 64(10), 2698-707 (Eng).

189. Dissociation and two-body emission in shock-heated bromine. I. Bromine in argon.

Boyd, R. K.; Burns, George; Lawrence, Thomas R.; Lippiatt, J. H. (Univ. Toronto, Toronto, Ont.).

J. Chem. Phys. 1968, 49(9), 3804-21 (Eng).

190. Dissociation and two-body emission in shock-heated bromine. II. Pure bromine.

Boyd, R. K.; Brown, J. D.; Burns, George; Lippiatt, J. H.

(Univ. Toronto, Toronto, Ont.).

J. Chem. Phys. 1968, 49(9), 3822-7 (Eng).

191. Determination of excitation cross sections of some $\mathrm{O}_{2}{ }^{+}$bands by the method of crossing beams.

Korol, V. I.; Kishdo, S. M.; Skubenich, V. V. (Uzhgorod, Uzhgorods'kii Derzhuniv., USSR) .

Ukr. Fiz. Zh. (Ukr. Ed.) 1968, 13(7), 1220-2 (Ukrain).

192. Rotational analysis for a perturbed ${ }^{1}$ II state in thorium oxide. Edvinsson, Gunnar; Bornstedt, Anita V.; Nylen, Per. Ark. Fys. 1968, 38(9), 193-218 (Eng).

193. The $2 p^{6}, 2 p^{5} 3 s, 2 p^{5} 4 s$ states of a neon atom. II. Oscillator strength and cross sections of excitation by electron collision. Vainshtein, L. A.; Minaeva, L. A.; Minaeva, L. A. (USSR). Zh. Prikl. Spektrosk. 1968, 9(1), 60-70 (Russ). CA Vol. 70, 15482 (1969).

194. Theory of polarization of molecular line radiation excited by electron impact.

Jette, A. Norman; Cahill, Patrick (Johns Hopkins Univ., Silver Spring, Md.).

Phys. Rev. 1968, 176 (1), 186-93 (Eng). 
195. Vibrational bending and stretching frequencies for $\mathrm{C}_{4}, \mathrm{C}_{5}$, and C6.

Sanborn, Russell H. (Lawrence Radiat. Lab., Univ. of California Iivermore, Calif.).

J. Chem. Phys. 1968, 49(9), 4219-21 (Eng).

196. Electronic transition moment of the nitrogen first positive system ( $\left.\mathrm{N}_{2} \mathrm{IPG}\right)$.

Cunio, B. E.; Jansson, Robert E. W. (Comput. Br., Cent. Elec. Generating Board, Southampton, Engl.).

J. Quant. Spectrosc. Radiat. Transfer 1968, 8(11), 1763-71 (Eng).

197. The 4750-A. band system of chlorine dioxide.

Richardson, A. W.; Redding, R. W.; Brand, John C. D. (Vanderbi.lt Univ., Nashville, Tenn.).

J. Mol. Spectrosc. 1969, 29(1), 93-108 (Eng).

198. Vibration-translational energy transfer according to the Morse potential.

Thomspon, Samuel I. (Sandia Lab., Albuquerque, N. Mex.). J. Chem. Phys. 1968, 49(8), 3400-10 (Eng).

199. Spectrum of magnesium III in the vacuum ultraviolet. Completion of magnesium IV.

Sulmont, Marie Christine; Felenbok, Paul (Obs. Paris-Meudon, Meudon, Fr.).

Ann Astrophys. 1967, 2, 315-40 (Fr). From CZ 1968, (29), Abstr. No. 86.

200. Helium standard light source for the vacuum ultraviolet spectral region. Simonenko, A. F. (USSR).

Zh. Prikl. Spektrosk. 1968, 9(2), 332-3 (Russ). CA Vol.70, 15631 (1969).

201. Second system ultraviolet spectrum of the aluminum monoxide molecule studied by using a cathode operating in the pulsed region.

Mahieu, J. M.; Becart, M. (Lab. Spectrosc. U. V., Fac. Sci., Lille, Fr.).

Can. Spectrosc. 1968, 13(4), 95-8, 110 (Fr).

202. Low-frequency spectra of the vapors of alkaline earth metal fluorides.

Baikov, V. I. (USSR).

Opt. Spektrosk. 1968, 25(3), 356-60 (Russ), CA Vol. 70, 15669 (1969). 
A. 203. Experimental oscillator strengths for the Schumann-Runge band system in oxygen.

Farmer, A. J. D.; Fabian, W.; Lewis, B. R.; Lokan, K. H.; Haddad, G. N. (Univ. Adelaide, Adelaide, Aust.).

J. Quant. Spectrosc. Radiat. Transfer 1968, 8(11), 1739-46 (Eng).

204. Absorption spectrum of diatomic cesium molecules.

Bayley, D. S.; Eberlin, E. C.; Simpson, J. H. (GPI Div., Gen. Precis. Systems Inc., Pleasantville, N. Y.).

J. Chem. Phys. 1968, 49(6), 2863-4 (Eng).

205. Study of emission spectra by phase-discrimination methods. Dickey, Fred P.; Rogge, William H.; Scott, Herman E.; Yane, John R.; White, John T. (Ohio State Univ. Res. Found., Columbus, Ohio).

U. S. Clearinghouse Fed. Sci. Tech. Inform., 1968, AD 669381 63 pp (Eng). Avail. CFSTI. From U. S. Govt. Res. Develop. Rep. 1968, 68(14), 54.

206. $4 f^{6} 6 s 6 p$ and $4 f^{5} 5 d 6 s^{2}$ odd-level configurations of samarium I. Carlier, Annik; Blaise, Jean; Schweighofer, Marie Gabrielle (Lab. Aime-Cotton, C. N. R. S., Orsay, Fr.).

J. Phys. (Paris) 1968, 29(8-9), 729-38 (Fr).

207. Spectral radiant intensity of a mercury injection lamp.

Voelker, Winfred (Max-Planck-Inst. Biophys., Frankfurt/M., Ger.). Biophysik 1968, 5(1), 66-70 (Ger).

208. Isotope shift studies of the ultraviolet and visible bands of $\mathrm{P} 16 \mathrm{O}$ and $\mathrm{P} 18 \mathrm{O}$.

Dixit, M. N.; Narasimham, N. A. (Spectrosc. Div., Bhabha At. Res. Centre, Trombay, India).

Proc. Indian Acad. Sci., Sect. A 1968, 68(1), 1-12 (Eng).

209. Transition probabilities for prominent argon I lines. Wiese, W. I. (Nat. Bur. of Stand., Washington, D. C.). Phenomena Ioniz. Gases, Int. Conf., Contrib. Pap., 8th, Vienna 1967, 447 (Eng).

210. Quenching and rotational relaxation of $\mathrm{OH}\left(\mathrm{A}^{2} \Sigma^{+} \mathrm{V}^{\prime}=0, \mathrm{~K}^{\prime}\right)$. Kley, D.; Welge, K. H. (Univ. Bonn, Bonn, Ger.). J. Chem. Phys. 1968, 49(6), 2870-1 (Eng).

211. Revised and extended analysis of the spectrum of calcium III. Borgstrom, Alf (Iund Inst. Technol., Lund, Swed.). Ark. Fys. 1968, 38(12), 243-60 (Eng). 
1. Jadeite stability measured in the presence of silicate liquids in the system sodium aluminosilicate-silica-water.

Boettcher, A. I. ; Wyllie, P. J. (Pennsylvania State Univ., University Park, Pa.).

Geochim. Cosmochim. Acta 1968, 32(9), 999-1012.

2. Stability of lawsonite.

Nitsch, K. H. (Univ. Goettingen, Goettingen, Ger.). Naturwissenschaften 1968, 55(8), 388 (Ger).

3. Kyanite-sillimanite equilibrium between $700^{\circ}$ and $1500^{\circ}$.

Richardson, S. W. ; BelI, P. M. ; Gilbert, M. C. (Carnegie Inst. of Washington, Washington, D.C.).

Amer. J. Sci. 1968, 266(7), 513-41.

4. An experimental investigation of oldhamite, CaS; and the petrologic significance of oldhamite in meteorites.

Larimer, John W. (Univ. of Chicago, Chicago, Ill.).

Geochim. Cosmochim. acta 1968, 32(9), 965-82.

5. Metal ion chemistry of the earth's atmosphere.

Ferguson, E. E.; Fehsenfeld, F. C. (Aeronom. Lab., Environ. Sci. Serv. Admin., Boulder, Colo).

J. Geophys. Res. 1968, 73(19), 6215-23.

6. Kinetics and conditions of condensation during the preparation of alkali metals (potassium and lithium) by a vacuum-thermal method.

Mikulinskii, A. S.; Sipeiko, I. E. (Inst. Met., Sverdlovsk, USSR). Redk. Shchelochnye Elem., Sb. Dokl. Vses. Soveshch., 2nd, Novosibirsk 1964, (Pub. 1967), 350-60 (Russ). Edited by

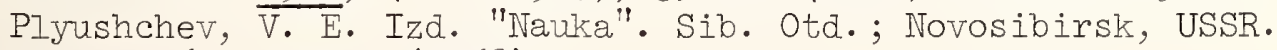
CA Vol. 69, 79325r (1968).

7. Thermodynamic activity of carbon in industrial silicothermic ferrochromium.

Kashkul, V. V.; Khitrik, S. I. ; Alekseev, V. I.; Ignat'ev, V. S.; Gasik, M. I.; Parnis, E. M. (Dnepropetrovsk. Met. Inst., Dnepropetrovsk, USSR).

Izv. Vyssh. Ucheb. Zaved., Chern. Met. 1968, II(7), 42-5 (Russ). CA Vol. 69, 79328u (1968).

8. Thermodynamic aspects of vacuum metallurgy.

Elliot, J. F. (Massuchusetts Inst. of Technol., Cambridge, Mass.). Vide 1968, 23(135), 123-50 (Eng/Fr). 
B. 9. Carburization of steel by methane-hydrogen mixtures.

Petrova, E. F.; Shvartsman, L. A. (USSR).

Izv. Akad. Nauk SSSR, Metal. 1968, (4), 80-3 (Russ). CA Vol. 69, 79398 (1968).

10. Kinetics of the oxidation of carbon in molten liquid iron. Medvedevskikh, Yu. G.; Esin, O. A.; Chuchmarev, S. K. (USSR). Izv. Akad. Nauk SSSR, Metal 1968, (4), 23-7 (Russ). CA. Vol. 69 79422 ( 1968 ).

11. Solubility of nitrogen and formationof nitrides in iron-niobium melts.

Isaev, V. F.; Morozov, A. N. (USSR).

Teor, Prakt. Met. 1966, INo.8, 144-8 (Russ). From Ref. Zh., Khim. 1967, Abstr. No. 14 4 B719. CA. Vol. 69, 79426 (1968).

12. Kinetics of oxygen absorption by metals of Group VA. III. The niobium-oxygen and tantalum-oxygen systems.

Hoerz, Gerhard (Max-Planck-Inst. Metallforsch., Stuttgart, Ger.). Z. Metallk. 1968, 59(4), 283-8 (Ger).

13. Kinetics of sulfiding molybdenum with sulfur vapors.

Zelikman, A. N.; Teslitskaya, M. V. (Mosk. Inst. Stali Splavov, Moscow, USSR).

Izv. Vyssh. Ucheb. Zaved., Tsvet. Met. 1968, 1I(2), 77-81 (Russ). CA Vol. 69, 79587 (1968).

14. Solubility of nitrogen in molten Kh20N80-type alloys with titanium, aluminum, and cerium additives.

Ivanov, E. G.; Stomakhin, A. Ya.; Filippov, A. F. (Mosk. Inst. Stali Splavov, Moscow, USSR) .

Izv. Vyssh. Ucheb. Zaved., Chern. Met. 1968, II(7), 46-8 (Russ). CA Vol. 69, 79679 (1968).

15. Breakaway oxidation transition for a zirconium-2.7 weight \% niobium alloy.

Cowgill, M. G.; Wong, S. H•; Smeltzer, W. W. (McMaster Univ•, Hamilton, Ont.). J. Electrochem. Soc. 1968, II5(9), (Eng).

16. Volatilization Ioss of sodium borosilicate ternary glasses. Shinbo, Masaru (Tokyo Shibaura Elec. Co., Ltd., Tokyo, Japan). Yogyo Kyokai Shi 1966, 74(855), 346-53 (Japan), CA Vol. 69, 79804 (1968).

17. Reaction between nitrogen and spinel in chromium. Scruggs, D. M.; Van Vlack, L. H.; Spurgeon, W. M. (Bendix Res. Lab., Southfield, Mich.).

J. Amer. Ceram. Soc. 1968, 51(9), 473-81 (Eng). 
B. 18. Reactions of excited atoms and molecules with atoms and molecules. I. Excited rare gas atoms and hydrogen. Hotop, H.; Niehaus, A. (Univ. Freiburg, Freiburg, Ger.). Z. Phys. 1968, 215(4), 395-407 (Eng).

19. Mass-spectrometric study of photoionization. XI. Hydrogen sulfide and sulfur dioxide.

Dibeler, Vernon H.; Liston, Susan D. (Inst. for Basic Stand., Nat. Bur. of Stand., Washington, D. C. ). J. Chem. Phys. 1968, 49(2), 482-5 (Eng).

20. Properties of thin metal films observed by field-ion and fieldemission micro-scopy.

Montagu-Pollock, H. M.; Rhodin, R. N.; Southon, M. J. (Univ . of Cambridge, Cambridge, Engl.).

Surface Sci. 1968, 12(1), 1-18 (Eng).

21. Vapor pressure of aluminum chloride in molten mixtures of aluminum and sodium chlorides.

Narita, Toshio; Ishikawa, Tatsuo; Midorikawa, Rinzo (Hokkaido Univ., Sapporo, Japan) .

Denki Kagaku 1968, 36(4), 300-5 (Japan). CA Vol. 69, 80471 (1968).

22. Partial pressure of $\mathrm{Se}_{2}(\mathrm{~g})$ in selenium vapor.

Brebrick, R. F. (Massachusetts Inst. of Tecinnol., Lexington, Mass.).

J. Chem. Phys. 1968, 48(12), 5741-3 (Eng).

23. Graphite triple point and solidus-liquidus interface experimentally determined up to $1000 \mathrm{~atm}$.

Schoessow, Glen J. (Univ. of Florida, Gainesville, Fla.).

Phys. Rev. Lett. 1968, 21(11), 738-41 (Eng).

24. Interaction of oxygen with tungsten.

Ageev, V. N. ; Ionov, N. I. (Fiz.-Tekh. Inst. im. Ioffe, Leningrad, USSR).

Zh. Tekh. Fiz. 1968, 38(7), 1149-56 (Russ) •

CA Vol. 69, 80538 (1968).

25. Interaction of gallium and arsenic molecular beams with gallium arsenide surfaces.

Arthur, J. R., Jr. (Bell Telph. Lab., Inc., Murray Hill, N. J.) . J. Appl. Phys. 1968, 39(8), 4032-4 (Eng).

26. Gaseous equilibria in portions of the system carbon-hydrogenoxygen-sulfur.

Speidel, David H.; Heald, Emerson F. (Pennsylvania State Univ., University Park, Pa.).

Bull. Miner. Ind. Exp. Sta., Pa. State Univ. 1967, No. 83, 58 pp. 
B. 27. Evaporation behavior and high-temperature thermal analysis of substoichiometric plutonium oxide for oxygen/plutonium ratio $1.51-2.00$.

Ohse, R. W.; Ciani, C. (EURA-Tom, Karlsruhe, Ger.).

Thermodyn. Nucl. Mater., Proc. Symp., Vienna 1967 (Pub. 1968) 545-57 (Eng). From Nucl. Sci. Abstr. 1968, 202(15), 31477.

28. Solubility of water in molten silicate.

Fuwa, Tasuku; Banya, Shiro; Fukushima, Tsutomu; Iguchi, Yasutaka (Tohoku Univ., Sendai, Japan).

Tetsu To Hagane 1967, 53(2), 91-100 (Japan). CA Vol. 69, 80865 (1968).

29. Hydration of negative ions in the gas phase.

Kebarle, P.; Arshadi, M.; Scarborough, J. (Univ. Alberta, Edmonton Alberta).

J. Chem. Phys. 1968, 49(2), 817-22 (Eng).

30. Effects of gold, palladium, and platinum on the liquid-gas-solid and equilibrium in the silver-oxygen system.

Shah, I. D.; Parlee, N. A. D. (Stanford Univ., Stanford, Calif.). Trans. Met. Soc. AIM (Amer. Inst. Mining, Met., Petrol. Eng.) 1968, 243 (9), 2015-17 (Eng).

31. Method of determining the Wagner interaction parameters using the torsion-effusion technique: application to the silverzinc-tin system.

Desre, P. (Lab. Thermodyn. Phys.-Chim. Met., Centre Nat. Rech. Sci., Grenoble, Fr.).

Thermodyn. Nucl. Mater., Proc. Symp., Vienna 1967 (Pub. 1968), 67-74 (Fr). From Nucl. Sci. Abstr. 1968, 22(15), 31389.

32. Stability of uranium carbide-uranium nitride solid solutions in the presence of free carbon.

Naoumidis, A.; Stoeck, H. J. (Kernforschungsanlage, Juelich, Ger.).

Thermodyn. Nucl. Mater., Proc. Symp., Vienna 1967 (Pub. 1968), 287-300 (Eng). From Nucl. Sci. Abstr. 1968, $\overline{22(15)}, 31467$. Int. At. Energy Agency: Vienna, Austria.

33. Thermodynamic study of sulfur hemioxide. Comparison of the conditions for stability of sulfur hemioxide ( $\left.\mathrm{S}_{2} \mathrm{O}\right)$ and sulfur oxide ( $\mathrm{SO}$ )

Hagemann, Robert; Botter, Rene; Nief, Guy; Roth, Etienne (C. E. N. -saclay, Gif-sur-Yvette, Fr.).

Ann. Genie Chim. 1967, (Pub. 1968), 3, 33-4l (Fr.). 
B. 34. Thermodynamic studies using mass spectrometry on the uraniumoxygen system.

Pattoret, A.; Drowart, J.; Smoes, S. (Univ. Libre Bruxelles, Brussels, Belg.).

Thermodym. Nucl. Mater., Proc. Symp., Vienna 1967 (Pub. 1968), 613-36 (Fr). Int. At. Energy Agency: Vienna, Austria.

35. Thermodynamic and kinetic studies in high-temperature chemistry. Drowart, J.; Pattoret, A.; Smoes, S.; Degreve, F.; Detry, D. (Univ. Libre Bruxelles, Brussels, Belg.). Advan. Mass Spectrom. 1966, 3, 931-43 (Fr).

36. Thermodynamic study of sulfur oxid4s by mass spectrometry. Botter, Rene; Hagemann, Robert; Nief, Guy; Roth, Etienne (CEA, C. E. N. ; Saclay, Fr.). Advan. Mass. Spectrom. 1966, 3, 951-72 (Fr).

37. The equilibrium thermodynamic properties of a high-temperature nitrogen-alkali-metal vapor mixture.

Park, Stephen K. (Iangley Sta., Langley Res. Center, Hampton, Va.). NASA Tech. Note 1967, TN D-4106 67 pp. (Eng).

38. Thermodynamic studyof liquid copper alloys. II. Activities of bismuth and antimony in liquid copper-base alloys by vapor pressure measurements.

Azakami, Tkaeshi; Yazawa, Akira (Tohoku Univ., Sendai, Japan). Nippon Kogyo Kaishi 1967, 83(4), 666-72 (Japan). CA Vol. 69 81099 (1968).

39. Thermodynamic properties of nonstoichiometric vanadium and titanium carbides.

Alekseev, V. I.; Panov, A. S.; Fiveiskii, E. V.; Shvartsman, I. A. (State Comm. At. Energy Recovery, Moscow, USSR).

Thermodyn. Nucl. Mater., Proc. Symp., Vienna 1967, (Pub. 1968), 435-47 (Russ). From Vienna, Austria; Nucl. Sci. Abstr. 1968, 22(15), 31472. Inst. At. Energy Agency.

40. Thermogravimetric study of the higher nitride of chromium (CrIV). Mills, T. (Aust.).

Aust. Commonwealth Dep. Supply, Aeronaut. Res. Lab., Rep. MET 1967, ARI Met. 69, 8 pp. (Eng).

41. Thermochemistry of antimony and antimony trioxide.

Boerboom, A. J. H.; Reyn, H. W.; Vugts, H. F.; Kistemaker, J. (Lab. Voor Massascheiding, Amsterdam, Neth.). Advan. Mass Spectrom. 1966, 3, 945-9 (Eng). 
B. 42. Dissociation behavior of uranium monocarbide.

Vozzella, P. A.; Miller, A. D.; DeCrescente, M. A. (Div.

Pratt and Whitney Aircraft, United Aircraft Corp., Middletown, Conn.).

J. Chem. Phys. 1968, 49(2), 876-81 (Eng).

43. Dissociation behavior of uranium monocarbide.

Vozzella, P. A.; Miller, A. D.; DeCrescente, M. A. (Div. Pratt and Whitney Aircraft, United Aircraft Corp., Middletown, Conn.). J. Chem. Phys. 1968, 49(2), 876-81 (Eng).

44. Crystal growth of $\mathrm{CrO}_{2}$.

Chamberland, B. I. (Central Res. Dept., E. I. du Pont de Nemours and Co., Wilmington, Del.).

Mater. Res. Bull. 1967, 2(9), 827-35 (Eng).

45. Anomalous hexagonal etch pits produced in the graphite-water vapor reaction.

Myers, G. E.; Gordon, M. Dzurus (Argonne Nat. Lab., Argonne, Ill.) Carbon (Oxford) 1968, 6(3), 422-3 (Eng).

46. Anomalous surface structures of gold.

Somorjai, G. A. (Univ. of California, Berkeley, Calif.).

Surface Sci., 1967, 8, 98-100 (Eng).

47. Crystal structure of solid solutions in the antimony trisulfideantimony triselenide system.

Abrikosov, N. Kh.; Ivlieva, V. I. (Inst. Met. im. Baikova, Moscow, USSR).

Izv. Akad. Nauk SSSR, Neorg. Mater. 1968, 4(6), 868-72 (Russ).

48. Evidence of a doubly ionized native donor in cadmium telluride. Whelan, R. C.; Shaw, D. (Univ. Hull, Hull, Engl.).

Phys. Status Solidi 1968, 29(1), 145-52 (Eng).

49. Mass spectrometric studies of high temperatures. XXVIII. Gaseous ternary oxides, LiMO and $\mathrm{LiMO}_{2}$.

Zmbov, K. F.; Ficalora, P.; Margrave, J. I. (Rice Univ., Houston, Tex.).

J. Inorg. Nucl. Chem. 1968, 30(8), 2059-65 (Eng).

50. Mass spectrometric study of cycloheptasulfur, $\mathrm{S}_{7}$, and cyclodecasulfur, $\mathrm{S}_{\perp 0}$.

Zahorzky, U. I. (Univ. Marburg, Marburg, Ger.).

Angew. Chem., Int. Ed. Engl. 1968, 7(8), 633 (Eng).

51. Preparation of thin layers of germanium and silicon by chemical hydrogen plasma transport.

Veprek, S.; Marecek, V. (Ceskoslov. Akad. Ved., Prague, Czech.). Solid-State Electron. 1968, 11(7), 683-4 (Eng). 
B. 52. Chemistry of molybdenum. VII. Disproportionation of molybdenum subchlorides.

Saeki, Yuzo; Matsuzaki, Ryoko; Matsushima, Tadahisa (Tokyo Inst. Tech., Tokyo, Japan).

Denki Kagaku 1967, 35(4), 298-302 (Japan).

CA. Vol. 69, 82986 (1968).

53. Deposition of niobium thin films by direct-current diode and substrate bias sputtering.

Sosniak, J. (Bell Teleph. Lab., Inc., Murray Hill, I. J.) . J. Appl. Phys. 1968, 39(9), 4157-63 (Eng).

54. Sputtering of metallic thin layers by 1000-10,000ev. molecular beams.

Devienne, F. Marcel; Roustan, Andre (Rech. Thermodyn., Nice, Fr.).

Entropie 1968, No. 20, 9-18 (Fr.).

55. Electronic partition functions of atoms and ions between $1500^{\circ} \mathrm{K}$. and $7000^{\circ} \mathrm{K}$.

DeGalan, I.; Smith, R.; Winefordner, J. D. (Univ. of Florida Gainesville, Fla.).

Spectrochim. Acta, Part B 1968, 23(8), 521-5 (Eng).

56. Determination of the saturated vapor pressure of solid bismuth selenide.

Boncheva-Mladenova, Z.; Pashinkin, A. S.; Novoselova, A. V. (Mosk. Gos. Univ. im. Lomonosova, Moscow, USSR). Izv. Akad. Nauk SSSR, Neorg. Mater. 1968, 4(7), 1027-3I (Russ). CA Vol. 69, 89841 (1968).

57. Field emission microscope studies of coadsorption of oxygen and cesium on refractory metals. Kuroda, Tsukasa; Nakamura, Shogo (Japan). Mem. Inst. Sci. Ind. Res., Osaka Univ. 1968, 25, 49-6I (Eng).

58. Adsorption studies based on thermionic emission measurements. III. Oxygen on polycrystalline tungsten, molybdenum, tantalum, and rhenium.

Greaves, W.; Stickney, R. E. (Massachusetts Inst. of Technol., Cambridge, Mass.).

Surface Sci. 1968, II(3), 395-410 (Eng).

59. Phase studies of the zirconium-hydrogen system at high hydrogen concentrations.

Moore, K. E.; Young, W. A. (At. Inst. Div., North Amer. Rockwell Corp., Canoga Park, Calif.).

J. Nucl. Mater. 1968, 27(3), 316-24 (Eng). 
B. 60. Isopiestic balance measurements of solvent vapor pressures over dilute liquid solutions of nickel in cadmium.

Conant, Donald R.; Elliott, Guy R. B. (Los Alamos Sci. Lab., Los Alamos, N. Mex.).

J. Chem. Eng. Data 1968, 13(3), 354-6 (Eng).

61. Thermodynamics of the vanadium pentoxide (solid or liquid)water vapor system.

Yannopoulos, I. N. (U. S. Army Nucl. Def. Lab., Edgewood Arsenal, Md. ) .

J. Phys. Chem. 1968, 72(9), 3293-6 (Eng).

62. Effect of dislocations on the vaporization rate of sodium chloride single crystals.

Lester, J. E.; Somorjai, G. A. (Univ. of California, Berkeley Calif.).

Appl. Phys. Lett. 1968, 12(6), 216-17 (Eng).

63. Disorder in cubic uranium sesquinitride.

Mueller, F.; Ragoss, H. (Kernforschungsanlage, Juelich, Ger.). Thermodyn. Nucl. Mater., Proc. Symp., Vienna 1967 (Pub. 1968), 257-64 (Eng). From Nucl. Sci. Abstr. 1968, 22(15), 31504. Int. At. Energy Agency: Vienna, Austria.

64. Formation and stability of the platinum and rhodium oxides at high oxygen pressures and the structures of $\mathrm{Pt}_{3} \mathrm{O}_{4}, \beta-\mathrm{PtO}_{2}$, and $\mathrm{PhO}_{2}$.

Muller, Olaf; Roy, Rustum (Pennsylvania State Univ., University Park, Pa.).

J. Less Common Metals 1968, 16(2), 129-46.

65. Role of mass spectrometry in high-temperature chemistry.

Drowart, J.; Goldfinger, P. (Univ. Iibre Bruxelles, Brussels, Belg. Advan. Mass Spectrom, 1966, 3, 923-30 (Eng).

66. Application of high-temperature mass spectrometry to the study of the composition function of thermodynamic properties in nonstoichiometric compounds.

Gingerick, K. A. (Pennsylvania State Univ., University Park, Pa.). Advan. Mass Spectrom. 1966, 3, 1009-16 (Eng).

67. Evaporation of molybdenum from the liquid phase. Batashev, V. I.; Morozov, A. A.; Reznichenko, V. A. (USSR). Met. Vol'frama, Molibdena Niobiya 1967, 133-5 (Russ). CA Vol. 69, 98907 (1968).

68. Resistometric study of the solution and precipitation of hydrides in unalloyed zirconium.

Mishima, Y.; Ishino, S.; Nakajima, S. (Univ. Tokyo, Tokyo, Japan). J. Nucl. Mater. 1968, 27(3), 335-44 (Eng). 
B. 69. Determination of hydrogen solubility in a-zirconium and its alloys with molybdenum and chromium.

Emel'yanov, V. S.; Borkov, N. V.; Buchkov, Yu. F.; Pishchagin, V. V. (USSR).

Met. Metalloved. Chist. Metal. 1967, No. 6, 46-51 (Russ). From Ref. Zh., Met. 1968, Abstr. No. 3116.

70. Solubility of hydrogen and deuterium in ultrapure aluminum from 400 to $600^{\circ}$.

Eichenauer, Walter (Tech. Hochseh. Darmstadt, Darmstadt, Ger.). Z. Metallk. 1968, 59(8), 613-16 (Ger).

71. Effect of ordering on the solubility of hydrogen in nickel-iron alloys.

Gol'tsov, V. A.; Gel'd, P. V.; Simakov, Yu. P.; Shteinberg, M. M.; Vykhodets, V. B. (Ural. Politekh. Inst. im. Kirova, Sverdlovsk, USSR).

Diffuz. Protsessy Metal. 1968, 92-4 (Russ). CA Vol. 69, 98926 (1968).

72. Vapor fractionation of silicate melts at high temperatures and atmospheric pressures.

Walter, Louis S.; Giutronich, J. E. (Goddard Space Flight Center, Greenbelt, Ma.).

Solar Energy 1967, 11(3-4), 163-9 (Eng).

73. Effect of chromia vaporization on the sintering of magnesia.

Hench, Larry, I.; Russell, Ralston, Jr. (Univ. of Florida, Gainesville, Fla.).

Trans. Brit. Ceram. Soc. 1968, 67(9), 377-90 (Eng).

74. Dissociation energy of diatomic manganese.

Kant, Arthur; Iin, Sin-Shong; Strauss, Bernard (Army Mater. and Mech. Res. Center, Watertown, Mass.).

J. Chem. Phys. 1968, 49(4), 1983-5 (Eng).

75. Formation of positive and negative ions on rhenium, oxygenated tungsten, hafnium, lanthanum hexaboride, and thoriated tungsten surfaces.

Persky, Avigdor; Greene, Edward F.; Kuppermann, Aron (California Inst. of Technol., Pasadena, Calif.).

J. Chem. Phys. 1968, 49(5), 2347-57 (Eng).

76. Effusion. II. Angular number distributions of gaseous cadmium from a right-circular cylindrical orifice into vacuum. Wahlbeck, P. G.; Phipps, T. E. (Univ. of Illinois, Urbana, Ill.). J. Chem. Phys. 1968, 49(4), 1603-8 (Eng). 
B. 77. III. Effusion. Angular number distribuations of gaseous cesium chloride from right-circular cylindrical orifices into vacuum.

Adams, J. Q.; Phipps, T. E.; Wahlbeck, P. G. (Univ. of Illinois, Urbana, Ill.).

J. Chem. Phys. 1968, 49(4), 1609-16 (Eng).

78. Effusion. IV. Angular number distributions of gaseous cesium chloride from right-circular cylindrical orifices into vacuum. Wang, K. C.; Wahlbeck, P. G. (Illinois Inst. of Technol., Chicago, Ill.).

J. Chem. Phys. 1968, 49(4), 1617-25 (Eng).

79. Atomization of oxygen on platinum.

Fusy, Jean; Weber, Bernard; Cassuto, Albert; Le Goff, Pierre (Centre Cinet. Phys. Chim., C. N. R. S., Villers-Nancy, Fr.). J. Chim. Phys. Physicochim. Biol. 1968, 65(6), 1192-3 (Fr).

80. Vaporization equilibrium of the system $\mathrm{Nb}_{3} I_{8}(\mathrm{~s})-\mathrm{Nb}_{6} \mathrm{I}_{11}(\mathrm{~s})$. Kust, Mary Angela; Corbett, John D.; Friedman, Robert M. (Iowa State Univ., Ames, Iowa). Inorg. Chem. 1968, 7(10), 2081-6 (Eng).

81. Vaporization and thermodynamics of the praseodymium and gadolinium sulfides, $\mathrm{Pr}_{3} \mathrm{~S}_{4}$ and GdS.

Fries, James A.; Cater, E. David (Univ. of Iowa, Iowa City, Iowa). U. S. At. Energy Comm. 1968, COO-1182-24, 33 pp. (Eng). Avail. Dep.; CFSTI. From Nucl. Sci. Abstr. 1968, 22 (13), 27515.

82. Silicon-tellurium system: partial pressures of $\mathrm{Te}_{2}$ and SiTe and thermodynamic properties from optical density of the vapor phase. Brebrick, R. F. (Massachusetts Inst. of Technol., Lexington, Mass.). J. Chem. Phys. 1968, 49(6), 2584-92 (Eng).

83. Mass spectrometric studies of plutonium compounds at high temperature II. Enthalpy of sublimation of plutonium(III) fluoride and the dissociation energy of plutonium(I) fluoride. Kent, R. A. (los Alamos Sci. Lab., Los Alamos, N. Mex.). J. Amer. Chem. Soc. 1968, 90(21), 5657-9 (Eng).

84. Growing of lead telluride crystals of stoichiometric composition in the vapor-gas phase. Mashaev, T. A.; Krapukhin, V. V.; Pavlov, S. P. (Mosk. Ord. Trud. Krasnogo Znameni Inst. Stali Splavov, Moscow, USSR). Khal'kogenidy (Svoistva, Metody Poluch. Primen.), Mater. Seminara, 1st, Kiev 1965, (Pub. 1967), 101-7 (Russ) CA Vol. 69 100342 (1968). 
B. 85. Mass spectrometric study of homogeneous nucleation in free jets. Milne, Thomas A.; Greene, Frank T. (Midwest Res. Inst., Kansas City, Mo.).

U. S. Clearinghouse Fed. Sci. Tech. Inform. 1967, AD 655292, 12 pp. (Eng). Avail. CFSTI. From U. S. Govt. Res. Develop. Rep. $1967,67(18), 54$.

86. Vapor-pressure investigations of impurity diffusion and solubility in $A(I I)-B(V I)$ compounds demonstrated for the system CaS:Au: $\mathrm{S}_{2}$. Nebauer, E. (Deut. Akad. Wiss., Berlin, Ger.). Phys. Status Solidi 1968, 29(1), 269-81 (Eng).

87. Mass spectrometry of the vapors over lead chloride-alkali metal chloride mixtures (alkali metal = sodium, potassium, rubidium, or cesium). II. Electron-impact studies. Bloom, H.; Hastie, J. W. (Univ. Tasmania, Hobart, Aust.). J. Chem. Phys. $1968,49(5), 2230-6$ (Eng).

88. Mass-spectrometric sampling of high-pressure, high-temperature sources.

Greene, Frank T.; Milne, Thomas A. (Math. and Phys. Div., Midwest Res. Inst., Kansas City, Mo.).

Advan. Mass Spectrom. 1966, 3, 841-50 (Eng).

89. Thermodynamics of nonstoichiometric uranium dioxide.

Perron, P. O. (Fuel Mater. Br., Chalk River Nucl. Lab., Chalk River, Can.).

At. Energy Can. Itd., Chalk River 1968, AECL-3072, 52 pp. (Eng). Avail. CAN.

90. Heat formation of uranium carbide and vapor pressure of $V$. Stroms, E. K.; Huber, E. F., Jr. (Los Alamos Sci. Lab., Los Alamos, N. Mex.).

J. Nucl. Mater. 1967, 23(1), 19-24 (Eng).

91. Heating element for a high temperature $\left(2500^{\circ} \mathrm{K}\right.$.) furnace in an oxidizing atmosphere.

Anthony, Anne Marie; Faucher, Michele (Lab. Echanges Term., C. N. R. S., Meudon, Fr.).

C. R. Acad. Sci., Paris, Ser. C. 1968, 267 (6), 444-7 (Fr).

92. Adaptation of the Cahm electrobalance control system to the automatic operation of a quartz-beam vacuum microbalance. Boggs, William E. (U. S. St.eel Corp., Monroeville, Pa.). Vac. Microbalance Tech. Igńn (Publ. 1967), 6, 45-58 (Eng).

93. Rate of evaporation of mangurese, copper, tin, chromium, and sulfur from molten iron under vacuum. Ohno, R.; Ishida, T. (Tokohu Univ., Sendai, Japan). J. Iron Steel Inst. (Iondon) 1968, 206 (Pt. 9), 904-8 (Eng). See CA 68: 61890. 
B. 94. Determination of the activities of aluminum in liquid aluminumiron binary alloys by the bubbling method.

Mitani, Hiroyasu; Nagai, Hiroshi (Osada Univ., Osada, Japan). Nippon Kinzoku Gakkaishi 1968, 32(8), 752-5 (Japan). CA Vol. 69, 109275 (1968).

95. Vapor pressure, the heat of sublimation, and the evaporation coefficient of praseodymium trifluoride.

Skinner, Harry B.; Searcy, Alan W. (Lawrence Radiat. Lab., Univ. of California, Berkeley, Calif.).

J. Phys. Chem. 1968, 72(10), 3375-81 (Eng).

96. Experimental determination of the saturated vapor pressure of rubidium.

Volyak, I. D.; Vinogradov, Yu. K.; Anisimov, V. M. (Mosk. Aviats. Inst., Moscow, USSR).

Teplofiz. Vys. Temp. 1968, 6(4), 754-5 (Russ) Ca. Vol. 69, 110078 (1968).

97. Vaporization characteristics of zinc chloride, bromide, and iodide.

Rice, Donald W.; Gregory, N. W. (Univ of Washington, Seattle Washington).

J. Phys. Chem. 1968, 72(10), 3361-6 (Eng).

98. Reaction of carbon monoxide with a tantalum surface heated above $2000^{\circ} \mathrm{K}$.

Scheer, Milton D.; Fine, Joseph (Nat. Bur. of Stand., Washington, D. C.).

Surface Sci. 1968, 12(1), 102-7 (Eng).

99. Thermodynamic properties of bismuth trifluoride.

Cubicciotti, Daniel (Stanford Res. Inst., Menlo Park, Calif.). J. Electrochem. Soc. 1968, 115(11), 1138-43 (Eng).

100. Thermodynamic properties of cerium gas.

Hawkins, Donald T.; Desai, Pramod D. (Lawrence Radiat. Lab., Univ. of California, Berkeley, Calif.).

J. Chem. Eng. Da.ta 1968, 13(4), 497-8 (Eng).

10l. Heats of formation of $\mathrm{AlClF}_{2}$ and $\mathrm{AlCl}_{2} \mathrm{~F}$ from subliming aluminum fluoride in the presence of aluminum chloride vapor. Krause, Ralph F., Jr.; Douglas, Thomas B. (Nat. Bur. of Stand., Washington, D. C.).

J. Phys. Chem. 1968, 72(10), 3444-51 (Eng). 
B. 102. Measurement of partial molar free energy of oxygen in uranium oxides $\left(\mathrm{UO}_{2+\mathrm{x}}\right.$ ) with small variations in stoichiometry.

Thomas, Catherine; Gerdanian, Paul; Dode, Maurice (Lab. Chim. Thermodyn., Fac. Sci.).

J. Chim. Phys. Physicochim. Biol. 1968, 65(7-8), 1349-58 (Fr).

103. Mass spectrometric studies at high temperatures. XXIX. Thermal decomposition and sublimation of alkali metal sulfates. Ficalora, P. J.; Uy, O. M.; Muenow, D. W.; Margrave, J. L. (Rice Univ., Houston, Tex.).

J. Amer. Ceram. Soc. 1968, 51(10), 574-7 (Eng).

104. Electron diffraction study of molecules of boron oxide and lithium metaborate.

Ezhov, Yu. S.; Tolmachev, S. M.; Spiridonov, V. P.; Rambidi, N. G. (Inst. Vys. Temp., Moscow, USSR).

Teplofiz. Vys. Temp. 1968, 6(1), 68-72 (Russ). CA Vol. 69, 110996 (1968).

105. High-temperature mass spectrometry: samarium dicarbide and neodymium (III) monotelluro oxide[oxytelluride].

Pilato, Philip Anthony (Michigan State Univ., East Lansing, Mich.). 1968, 162 pp. (Eng). Avail. Univ. Microfilms, Ann Arbor Mich., Order No. 68-11,087. From Diss. Abstr. B 1968, 29(2),

106. Effect of aluminum on the activity of sulfur in nickel-base melts.

Dashevskii, V. Ya.; Polyakov, A. Yu. (USSR). Fiz.-Khim. Osn. Proizvod. Stali 1968, 49-52 (Russ). CA Vol. 69 110546 (1968).

107. Solubility of nitrogen in $\alpha$-iron. Milinskaya, I. N. ; Tomilin, I. A. (USSR). Izv. Akad. Nauk SSSR, Metal. 1968, (5), 132-5 (Russ). CA Vol. 70 6085 (1969).

108. Solubility of hydrogen in nickel-chromium and nickel-silicon alloys. Schenck, Hermann; Lange, Klaus W. (Rheinisch-Westfael. Tech. Hochsch. Aachen, Aachen, Ger.). Arch. Eisenhuettenw. 1968, 39(9), 673-6 (Ger).

109. Quaternary system uranium-carbon-oxygen-nitrogen at $1700^{\circ} \mathrm{C}$. Phase relations in the low-nitrogen region. Henry, Jack L.; Blickensderfer, Robert; Thompson, Gerald G. (Albany Met. Res. Center, Bur. of Mines, Albany, Oreg.). J. Amer. Ceram. Soc. 1968, 51(II), 617-21 (Eng). 
B. 110. Applications of diatomics-in-molecules theory. II. Prediction of a stable Iiz molecule.

Campanion, Audrey L.; Steible, Daniel J. Jr.; Starshak, Albert J. (Illniois Inst. of Technol., Chicago, IIl).

J. Chem. Phys. 1968, 49(8), 3637-40 (Eng).

111. Solubility and diffusion of hydrogen and deuterium in platinum. Ebisuzaki, Yukiko; Kass, W. J.; O'Keeffe, Michael (Arizona State Univ., Tempe, Ariz.).

J. Chem. Phys. 1968, 49(8), 3329-32 (Eng).

112. Rate of vaporization of arsenic single crystals and the vaporization coefficient of arsenic.

Rosenblatt, Gerd M.; Lee, Pang-Kai (Pennsylvania State Univ., University Park, Pa.).

J. Chem. Phys. 1968, 49(7), 2995-3006 (Eng).

113. Mass-spectrometric studies at high emperatures. XXX. Vaporization of gallium sulfide, gallium selenide, and gallium telluride and stabilities of the gaseous gallium challcogenides.

Uy, Oscar M.; Muenow, David W.; Ficalora, Peter J.; Margrave, John L. (Rice Univ., Houston, Tex.).

Trans. Faraday Soc. 1968, 64(11), 2998-3005 (Eng).

114. Shock-tube method for determining the vapor pressures of refractory metals at high temperatures.

Falk, Theodore J. (Cornell Aeron. Lab., Inc., Buffalo, N. Y.). J. Chem. Phys. 1968, 49(8), 3727-8 (Eng).

115. Low energy electron diffraction studies of gas adsorption on the phatinum (100) single crystal surface. Morgan, A. E.; Somorjai, Gabor A. (Univ. of California, Berkeley, Calif.).

Surface Sci. 1968, 12(3), 405-25.

116. Solubility of sulfur in silver in equilibrium with hydrogenhydrogen sulfide mixtures.

Oudar, Jacques; Barbouth, Nisso (Ecole Nat. Super. Chim. Paris, Paris, Fr.).

C. R. Acad. Sci., Paris, Ser. C 1968, 267(10), 644-7 (Fr.).

117. Vapor pressure of sodium-lead alloy. I. Dissociation equilibrium of sodium vapor and vapor pressure of sodium-lead alloy ( $1: 1)$. Shinozaki, Heima; Kurata, Yoshiro (Yamagata Univ., Yonezawa, Japan).

Yamagata Daigaku Kiyo Kogaku 1968, 10(1), 1-8 (Japan). 
B. 118. Vaporization of carbon.

Palmer, Howard B.; Shelef, Mordecai (Pennsylvania State Univ., University Park, $\mathrm{Pa}$.).

Chem. Phys. Carbon 1968, 4, 85-135 (Eng).

119. Dissociation energies of GeCu, GeCo, GeFe, and CeCr[germanium intermetallic compounds].

Kant, Arthur; Strauss, Bernard H. (Army Mater. and Mech.

Res. Center, Watertown, Mass.).

J. Chem. Phys. 1968, 49(8), 3579-82 (Eng).

120. Dissociation energies of gaseous alkaline earth hydroxides.

Cotton, D. H.; Jenkins, Dennis R. (Thornton Res. Center, "Shell" Res. Itd., Chester, Engl.).

Trans. Faraday Soc. 1968, 64(11), 2988-97 (Eng).

121. Evaporation mechanism of sodium chloride single crystals. Lester, J. E.; Comorjai, Gabor A. (Lawrence Radiat. Lab., Univ. of California, Berkeley, Calif.).

J. Chem. Phys. 1968, 49(7), 2940-9 (Eng).

122. Mass-spectrometric determination of the dissociation energies of gaseous ruthenium monocarbide, iridium monocarbide, and platinum monoboride.

McIntyre, N. S.; Vander Auwera-Mahieu, A.; Drowart, Jean (Univ. Libre, Brussels, Belg.).

Trans. Faraday Soc. 1968, 64(11), 3006-10 (Eng).

123. Spectrophotometric study of bromine and iodine vapors.

Evidence for tetra-atomic molecules.

Passchier, Arie A. (Univ of Washington, Seattle, Wash.). 1968, 178 pp. (Eng). Avail. Univ. Microfilms, Ann Arbor, Mich., Order No. 68-12,709. From Diss. Abstr. B 1968, 29(3), 969.

124. Electronic emission and ionic reflection of a rare gas ionbombarded molybdenum target.

Perdrix, Michel; Paletto, S.; Goutte, Robert; Guillaud, Clement (Inst. Nat. Sci. Appl., Villeurbanne, Fr.).

Brit. J. Appl. Phys. 1968, [2]1(11), 1517-28 (Fr).

125. Possible error in the calibration of Knudsen cells by mercury effusion.

Northrop, David A. (Sandia Lab., Albuquerque, N. Mex.). J. Phys. Chem. 1968, 72(12), 4323-5 (Eng). 
B. 126. Some of the parameters affecting Knudsen effusion. IV. Monte Carlo calculations of effusion probabilities and flux gradients for Knudsen cells.

Ward, John William; Fraser, Malcolm V. (Ios Alamos Sci. Lab., Los Alamos, N. Mex.).

J. Chem. Phys. 1968, 49(9), 3743-50 (Eng).

127. Solubility of hydrogen in barium metal.

Peterson, Davia T.; Hammerberg, C. C. (Iowa State Univ., Ames, Iowa).

J. Less-Common Metals 1968, 16(4), 457-60 (Eng).

128. Evaporation of hypostoichiometric plutonium dioxide from 2070 to $2380^{\circ} \mathrm{K}$.

Messier, Donald R. (Argonne Nat. Iab., Argonne, Ill.).

J. Amer. Ceram. Soc. 1968, 51(12), 710-13.

129. Heterogeneous gas equilibriums of oxidic mixed phases and alloys. Schmahl, N. G. (Univ. Saarlandes, Saarbruecken, Ger.).

Fortschr. Chem. Forsch. 1968, 10(4), 583-630 (Ger).

130. Thermodynamics of carbide formation and graphite solubility in the calcia-silica-alumina system.

Swisher, J. H. (Bell Teleph. Lab., Murray Hill, N. J. ). Trans. Met. Soc. AIME (Amer. Inst. Mining, Met., Petrol. Eng.) 1968, 242(10), 2033-7 (Eng).

131. Solubility and diffusivity of oxygen in solid copper. Pastorek, Ronald I. (Ohio State Univ., Columbus, Ohio). 1968168 pp. (Eng). Avail. Univ. Microfilms, Ann Arbor, Mich., Order No. 68-12, 867. From Diss. Abstr. B 1968, 29(3), 1036.

132. Mass spectrometric studies of laser-induced vaporization. III. Arsenic-selenium system.

Knox, Bruce E.; Ban, Vladimir S. (Pennsylvania State Univ., University Park, Pa.).

Mater. Res. Bull. 1968, 3 (11), 885-94 (Eng).

133. High-speed calorimetry in the iron-carbon system between $600^{\circ}$ and $1600^{\circ}$.

Yamaguchi, Ko (Pennsylvania State Univ., University Park, Pa.). 1967, 108 pp. (Eng). Avail. Univ. Microfilms, Ann Arbor, Mich., Order No. 68-12,016. From Diss. Abstr. B 1968, 29(3), 1038.

134. Mass spectrometric determination of dissociation energies of gaseous indium sulfides, selenides, and tellurides. Colin, Reginald; Drowart, Jean (Univ. Liber Bruxelles, Brussels, Belg.).

Trans Faraday Soc. 1968, 64(10), 2611-21 (Eng). 
3. 135. Entropy and thermodynamic functions of $\mathrm{As}_{4}(\mathrm{~g})$.

Capwell, Robert J., Jr.; Rosenblatt, Gerd M. (Pennsylvania

State Univ., University Park, Pa.).

J. Phys. Chem. 1968, 72 (12), 4327-9 (Eng).

136. Negative-ion mass spectra of benzene, naphthalene, and anthracene A new technique for obtaining relatively intense and reproducible negative-ion mass spectra.

Dougherty, Ralph C.; Weisen berger, C. R. (Ohio State Univ., Columbur, Ohio).

J. Amer. Chem. Soc. 1968, 90(23), 6570-1 (Eng).

137. Structure of $x$-ray emission IIII bands of nickel in some alloys. Volkov, V. F.; Blokhin, M. A. (Rostov. na-Donu Gosuniv., Rostov-on-Don, USSR).

Fiz. Metal. Metalloved. 1968, 26(2), 376-7 (Russ). CA Vol. 70 15495 (1969).

138. Hydrothermal transport and deposition of gold.

Helgeson, Harold C.; Garrels, Robert M. (Northwestern Univ.,

Evanston, IIl.).

Econ. Geol. 1968, 63(6), 622-35 (Eng).

139. Equilibrium between aluminum and nitrogen in liquid $18 \%$ chromium $8 \%$ nickel stainless steel.

Jones, F. G.; Gardner, H. E.; Pehlke, Robert D. (Univ. of Michigan, Ann Arbor, Mich).

Trans. Met. Soc. AIME (Amer Inst. Mining, Met., Petrol. Eng.) 1968 242(12), 2453-6 (Eng).

140. Nitrogen solubility in liquid iron-chromium-nickel alloys.

Blossey, Robert G.; Pehlke, Robert D. (Univ. of Michigan, Ann Arbor, Mich.).

Trans. Met. Soc. AIME (Amer. Inst. Mining, Met., Petrol. Eng.) 1968, 242(12), 2457-9 (Eng).

141. Sulfur solubility and internal sulfidation of iron-titanium alloys.

Swisher, James H. (Bell Teleph. Lab., Murray Hill, N. J.). Trans. Met. Soc. AIME (Amer. Inst. Mining, Met., Petrol. Eng.) 1968, 242(12), 2433-9 (Eng).

142. The effect of alloying elements on the solubility of nitrogen in liquid iron-chromium-nickel alloys.

Small, W. M.; Pehlke, Robert D. (Univ of Michigan, Ann Arbor Mich.).

Trans. Met. Soc. AIME (Amer. Inst. Mining, Met., Petrol. Eng.) 1968, 242(12), 2501-5 (Eng). 


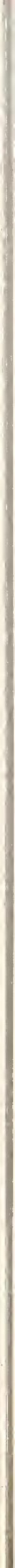




\section{Announcement of New Bibliographies on the High Temperature Chemistry and Physics of Materials}

Superintendent of Documents, Government Printing Office, Washington, D.C. 20402

Dear Sir:

Please add my name to the announcement list of new publications to be issued in the series: National Bureau of Standards Special Publication 315 .

Name

Company

Address

City

State

Zip Code

(Notification Key N-380) 


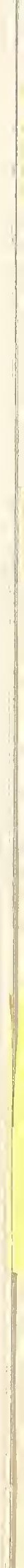

